\title{
ॠUSGS
}

science for a changing world

Studies by the U.S. Geological Survey in Alaska, 2007

\section{Detrital Zircon Geochronology of Cretaceous and Paleogene Strata Across the South-Central Alaskan Convergent Margin}

Professional Paper 1760-F

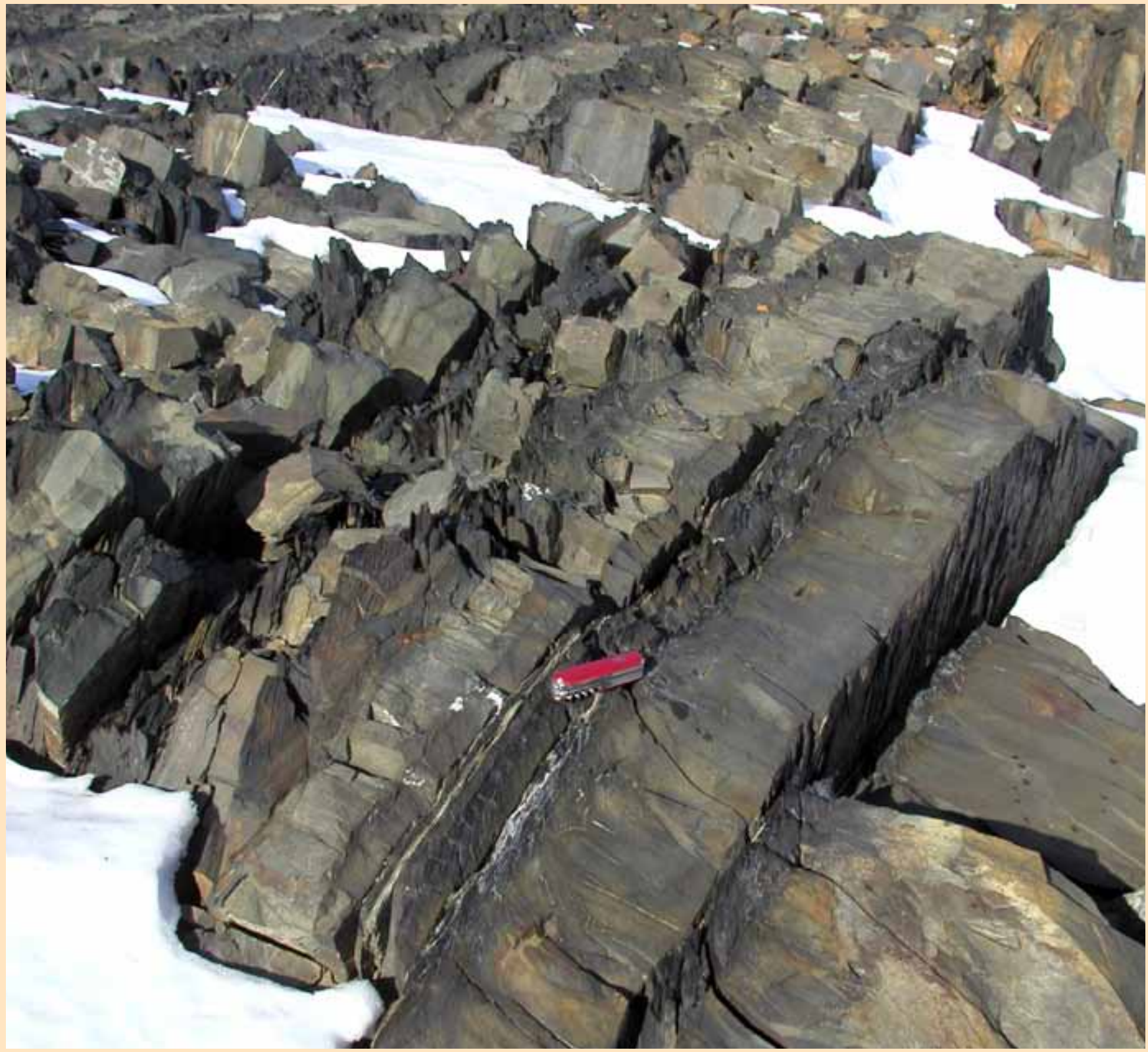

U.S. Department of the Interior

U.S. Geological Survey 
This page intentionally left blank 
Studies by the U.S. Geological Survey in Alaska, 2007

\section{Detrital Zircon Geochronology of Cretaceous and Paleogene Strata Across the South-Central Alaskan Convergent Margin}

By Dwight Bradley, Peter Haeussler, Paul O'Sullivan, Rich Friedman, Alison Till, Dan Bradley, and Jeff Trop

Professional Paper 1760-F

U.S. Department of the Interior

U.S. Geological Survey 


\title{
U.S. Department of the Interior KEN SALAZAR, Secretary
}

\section{U.S. Geological Survey Suzette M. Kimball, Acting Director}

\section{U.S. Geological Survey, Reston, Virginia: 2009}

This report and any updates to it are available online at: http://pubs.usgs.gov/pp/1760/f/

\author{
For more information about the USGS and its products: \\ Telephone: 1-888-ASK-USGS (1-888-275-8747) \\ World Wide Web: http://www.usgs.gov/ \\ Any use of trade, product, or firm names in this publication is for descriptive purposes only and \\ does not imply endorsement by the U.S. Government. \\ Although this report is in the public domain, it may contain copyrighted \\ materials that are noted in the text. Permission to reproduce those items \\ must be secured from the individual copyright owners.
}

Produced in the Western Region, Menlo Park, California

Manuscript approved for publication, August 20, 2009

Text edited by Peter H. Stauffer

Layout and design by Stephen L. Scott

\section{Suggested citation:}

Bradley, D., Haeussler, P., O'Sullivan, P., Friedman, R., Till, A., Bradley, D., and Trop, J., 2009, Detrital zircon geochronology of Cretaceous and Paleogene strata across the south-central Alaskan convergent margin, in Haeussler, P.J., and Galloway, J.P., Studies by the U.S. Geological Survey in Alaska, 2007: U.S. Geological Survey Professional Paper 1760-F, $36 \mathrm{p}$.

FRONT COVER

Exposure of Upper Cretaceous sandstone of the Valdez Group on the southern Kenai Peninsula, Alaska, that was sampled for zircon geochronology studies. 


\section{Contents}

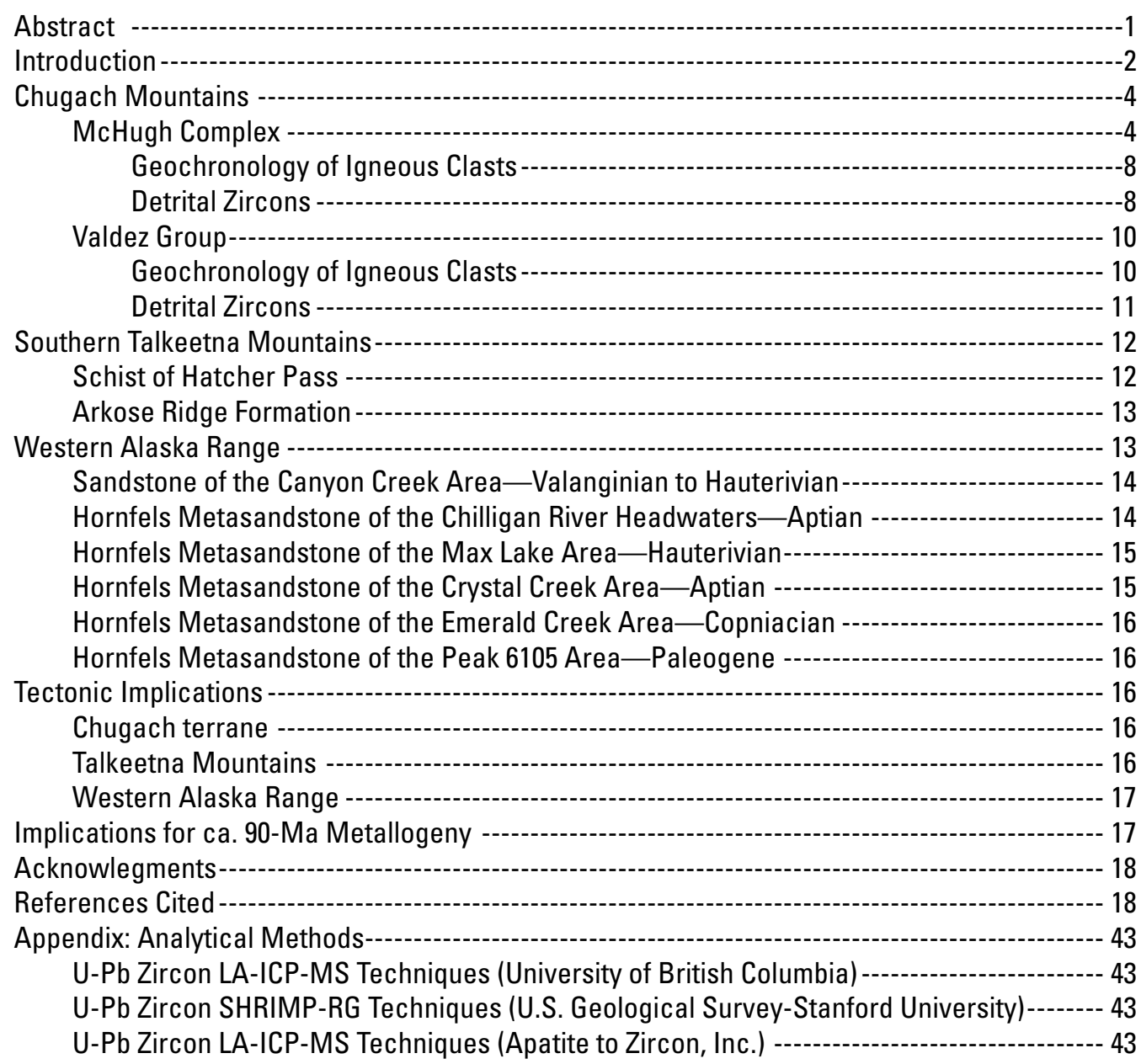

\section{Figures}

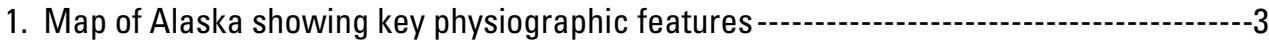

2. Simplified geologic map of parts of the Tyonek, Anchorage, Seward, and Kenai

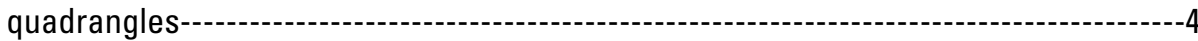

3. Histograms (blue boxes) and probability plots (red lines) of detrital zircon ages----------6

4. Outcrop photographs of rock units sampled for geochronology-

5. Individual ${ }^{206} \mathrm{~Pb} / 238 \mathrm{U}$ ages of zircon grains from igneous clasts -

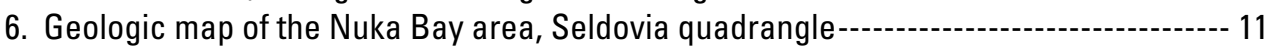

\section{Tables}

1. Analytical data and estimated resources for Cutaway Basin barite deposits --------------5

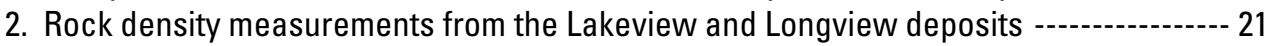


This page intentionally left blank 


\title{
Detrital Zircon Geochronology of Cretaceous and Paleogene Strata Across the South-Central Alaskan Convergent Margin
}

\author{
By Dwight Bradley ${ }^{1}$, Peter Haeussler'1, Paul 0'Sullivan², Rich Friedman³ ${ }^{3}$ Alison Till', Dan Bradley', and \\ Jeff Trop ${ }^{5}$
}

\section{Abstract}

Ages of detrital zircons are reported from ten samples of Lower Cretaceous to Paleogene metasandstones and sandstones from the Chugach Mountains, Talkeetna Mountains, and western Alaska Range of south-central Alaska. Zircon ages are also reported from three igneous clasts from two conglomerates. The results bear on the regional geology, stratigraphy, tectonics, and mineral resource potential of the southern Alaska convergent margin.

Chugach Mountains - The first detrital zircon data are reported here from the two main components of the Chugach accretionary complex - the inboard McHugh Complex and the outboard Valdez Group. Detrital zircons from sandstone and two conglomerate clasts of diorite were dated from the McHugh Complex near Anchorage. This now stands as the youngest known part of the McHugh Complex, with an inferred Turonian (Late Cretaceous) depositional age no older than 91-93 Ma. The zircon population has probability density peaks at 93 and $104 \mathrm{Ma}$ and a smattering of Early Cretaceous and Jurassic grains, with nothing older than $191 \mathrm{Ma}$. The two diorite clasts yielded Jurassic U-Pb zircon ages of 179 and 181 Ma. Together, these findings suggest a Mesozoic arc as primary zircon source, the closest and most likely candidate being the Wrangellia composite terrane. The detrital zircon sample from the Valdez Group contains zircons as young as 69 and $77 \mathrm{Ma}$, consistent with the previously assigned Maastrichtian to Campanian (Late Cretaceous) depositional age. The zircon population has peaks at $78,91,148$, and $163 \mathrm{Ma}$, minor peaks at $129,177,330$, and $352 \mathrm{Ma}$, and no concordant zircons older than Devonian. A granite clast from a Valdez Group conglomerate yielded a Triassic U-Pb zircon age of $221 \mathrm{Ma}$. Like the McHugh Complex, the

${ }^{1}$ U.S. Geological Survey, 4210 University Drive, Anchorage, AK 99508 USA.

2Apatite to Zircon, Inc., 1075 Matson Rd., Viola, ID 83872 USA.

${ }^{3}$ Dept. of Earth and Ocean Sciences, University of British Columbia, Vancouver, BC V6T1Z4, Canada.

${ }^{4}$ Alaska Pacific University, Anchorage, AK 99508.

${ }^{5}$ Dept. of Geology, Bucknell University, Moore Avenue, Lewisburg, PA 17837, USA.
Valdez Group appears to have been derived almost entirely from Mesozoic arc sources, but a few Precambrian zircons are also present.

Talkeetna Mountains -Detrital zircons ages were obtained from southernmost metasedimentary rocks of the Talkeetna Mountains (schist of Hatcher Pass) and, immediately to the south, the northernmost sedimentary sequence of the Matanuska forearc basin (Arkose Ridge Formation). Detrital zircons from the Paleogene Arkose Ridge Formation are as young as 61 and $70 \mathrm{Ma}$; the population is dominated by a single Late Cretaceous peak at $76 \mathrm{Ma}$; the oldest zircon is $181 \mathrm{Ma}$. Sedimentological evidence clearly shows that the conglomeratic Arkose Ridge Formation was derived from the Talkeetna Mountains; our detrital zircon data support this inference. Zircons dated at ca. $90 \mathrm{Ma}$ in the Arkose Ridge sample suggest that buried or unmapped plutons of this age may exist in the Talkeetnas. This is a particularly interesting age as it corresponds to the age of the supergiant Pebble gold-molybdenum-copper porphyry prospect near Iliamna and suggests a new area of prospectivity for Pebble-type deposits. The schist of Hatcher Pass, which was previously assigned a Jurassic depositional age, yielded surprisingly young Late Cretaceous detrital zircons, the youngest at 75 Ma. The probability density curve has four Cretaceous peaks from 76 to $102 \mathrm{Ma}$, a pair of Late Jurassic peaks at 155 and 166 Ma, three Early Jurassic to Late Triassic peaks at 186, 197, and $213 \mathrm{Ma}$, minor Carboniferous peaks at 303 and $346 \mathrm{Ma}$, and a minor Paleoproterozoic peak at $1828 \mathrm{Ma}$. The schist of Hatcher Pass was largely derived from Mesozoic arc sources, most likely the Wrangellia composite terrane, with some contribution from one or more older, inboard sources, probably including the Yukon-Tanana terrane. We postulate that the schist of Hatcher Pass represents metamorphosed rocks of the Valdez Group that were subducted and then exhumed along the Chugach terrane's "backstop" during Paleogene transtension.

Western Alaska Range - Six detrital zircon samples were collected from a little studied belt of turbidites in Tyonek quadrangle on strike with the Kahiltna assemblage of the central Alaska Range. Many of the sandstones are contact metamorphosed. On the basis of their youngest zircons, two similar samples are here assigned Early Cretaceous (Valanginian to Hauterivian and Aptian) depositional ages. Their detrital populations consist entirely of Jurassic and Early Cretaceous grains, 
having peaks at 153 and $152 \mathrm{Ma}$, respectively. Two other similar samples are also assigned Early Cretaceous (Hauterivian and Aptian) depositional ages, but they differ from the first two by also containing Precambrian grains. One of these samples has probability density peaks at 149 and $181 \mathrm{Ma}$, and the other has peaks at 141, 168, and 944 Ma. The four Early Cretaceous samples appear to have been mainly derived from Jurassic to Early Cretaceous arc sources of the Wrangellia composite terrane, with minor input from older, inboard sources such as the Yukon-Tanana and Farewell terranes. These four samples can be reasonably assigned to the Kahiltna assemblage. One western Alaska Range sample is assigned a Late Cretaceous depositional age of ca. $86 \mathrm{Ma}$; it has probability density peaks at 100 and $153 \mathrm{Ma}$ and contains a substantial proportion of Precambrian grains. Its zircon population appears to have been derived from Jurassic and Cretaceous arc sources as well as from older inboard rocks, such as the Yukon-Tanana terrane. The zircon age distribution is reminiscent of that of the Upper Cretaceous Kuskokwim Basin of southwest Alaska. Finally, one Alaska Range sample, for which an Early Cretaceous age was expected, instead yielded abundant Paleogene zircons, the youngest at $55 \mathrm{Ma}$. This sample has a single probability density peak at 65 $\mathrm{Ma}$, reflecting derivation from an Alaska Range arc that was active during latest Cretaceous and Paleogene times. The older Alaska Range samples are believed to record deposition in an Early Cretaceous syncollisional suture, and the younger samples are interpreted to be deposits of a Late Cretaceous to Paleogene retroarc basin.

\section{Introduction}

In the rapidly advancing field of detrital zircon geochronology, a broad goal among Alaskan researchers is to obtain baseline data for each of the major bedrock units that contain sandstone or metasandstone. Such data can yield several types of information that bear on problems of regional geology and tectonic evolution. In active tectonics settings, detrital zircons commonly provide new age constraints on the depositional age of the host sandstone or metasandstone, which can be no older than the youngest concordant zircons. This is especially important in strata that are devoid of fossils, a condition linked to the age of the strata, the depositional environment, the state of deformation, the state of metamorphism, a lack of mapping, or some combination of these factors. Detrital zircon age distributions (illustrated using probability density plots, or "barcodes") can be used to evaluate possible connections between sandstone-bearing stratigraphic units. This information has applications in geologic mapping at the quadrangle scale, for example in assigning problematic rocks to one or another map unit, and on a regional scale in matching displaced parts of an originally continuous sedimentary or metasedimentary succession. Finally - and this is the goal that led to the worldwide explosion of detrital zircon research in the first place - detrital zircons can be linked to possible bedrock source regions by their ages. Information of the latter type, in turn, can bear on the timing of juxtaposition of terranes and on basin evolution at an otherwise unattainable level of detail.

In this paper, we present new U-Pb detrital zircon data from a transect across the convergent margin of south-central Alaska (figs. 1 and 2; table 1). Two detrital zircon samples were collected to help constrain the depositional ages and provenance of the two main map units of the Chugach terrane (fig. 1B): the Valdez Group and McHugh Complex (Plafker and others, 1994). We also report U-Pb ages of plutonic clasts in the Valdez Group and McHugh Complex. Two other samples, from the southern Talkeetna Mountains, were collected to shed light on Paleocene evolution of the forearc basin during the time of ridge subduction (Bradley and others, 2003). Six samples are from the western Alaska Range, which during the Early Cretaceous was the site of a thickly sedimented collisional suture (Kalbas and others, 2007) and since then has been near the axis of a magmatic arc. The Alaska Range samples were collected as an aid to reconnaissance-scale geologic mapping in a seemingly monotonous expanse of deformed, fossil-poor, hornfels turbidites in the Tyonek quadrangle.

The data reported here were obtained using two techniques (LA-ICP-MS ${ }^{8}$ and SIMS $^{9}$ ) and three different labs. Analytical methods are detailed in the appendix. For the "best age" in table 2 , we have quoted the ${ }^{206} \mathrm{~Pb} /{ }^{238} \mathrm{U}$ age for zircons younger than $1000 \mathrm{Ma}$ and the ${ }^{207} \mathrm{~Pb} /{ }^{206} \mathrm{~Pb}$ age for older zircons; if one age is below the cutoff and the other is above, we have quoted the ${ }^{207} \mathrm{~Pb} /{ }^{206} \mathrm{~Pb}$ age. Except as noted, in constructing the plots in Figure 3, filters were applied to screen out results with unacceptably large analytical errors and unacceptable discordance. For all of the histograms and probability plots (fig. 3), we discounted any ages that have large errors, that is, analyses for which the 2-sigma error is $>5$ percent of the age. For these types of plots, most detrital zircon geochronologists also discount ages having high discordance. However, neither the way discordance is calculated nor the threshold for rejection are uniformly applied. In the data reported by University of British Columbia and Apatite to Zircon, Inc., discordance is calculated as:

$$
\left(\left(\left({ }^{207} \mathrm{~Pb} /{ }^{206} \mathrm{~Pb} \text { age }\right)-\left({ }^{206} \mathrm{~Pb} /{ }^{238} \mathrm{U} \text { age }\right)\right) /\left({ }^{207} \mathrm{~Pb} /{ }^{206} \mathrm{~Pb} \text { age }\right)\right) * 100
$$

In the data obtained on the SHRIMP-RG, discordance is calculated as:

$$
\left(\left(\left({ }^{207} \mathrm{~Pb} /{ }^{206} \mathrm{~Pb} \text { age }\right)-\left({ }^{206} \mathrm{~Pb} /{ }^{238} \mathrm{U} \text { age }\right)\right) * 100\right)-100
$$

Whichever way it is calculated, discordance is expressed as a percentage. For most samples, we have rejected ages that are $>10$ percent normally (+) or reversely (-) discordant, a threshold

\footnotetext{
${ }^{8}$ Laser-ablation inductively coupled plasma mass-spectrometry.

${ }^{9}$ Secondary ion mass spectrometry, in this study using a SHRIMP-RG, or sensitive high resolution ion microprobe-reverse geometry.
} 

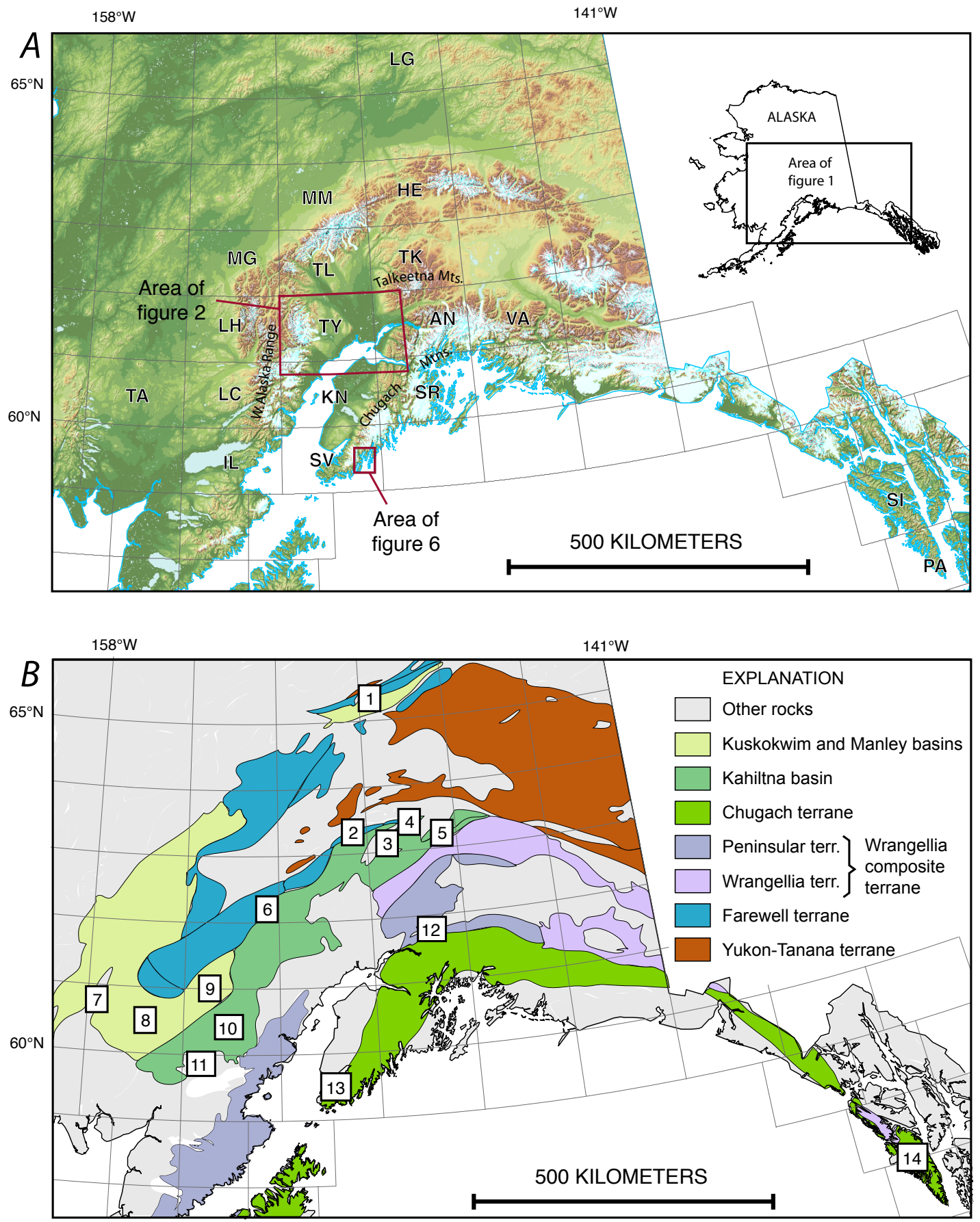

Figure 1. (A) Map of Alaska showing key physiographic features and the areas of figures 2 and 6 outlined in red. The black grid shows the outlines of 1:250,000-scale quadrangles, which are identified by the following abbreviations: AN, Anchorage; HE, Healy; IL, lliamna; KN, Kenai; LC, Lake Clark; LG, Livengood; LH, Lime Hills; MG, McGrath; MM, Mount McKinley; PA, Port Alexander; SI, Sitka; SM, Sleetmute; SR, Seward; SV, Seldovia; TA, Taylor Mountains; TK, Talkeetna Mountains, TL, Talkeetna; VA, Valdez. (B) Generalized terrane map of the same region. Numbers in white boxes refer to localities mentioned in text, as follows: 1, Minto Unit, Livengood quadrangle; 2, Cantwell Formation, Denali area; 3, Kahiltna assemblage, Broad Pass area; 4, Caribou Pass Formation; 5, Kahiltna assemblage, Clearwater Mountains; 6, Kahiltna assemblage, Terra Cotta Mountains; 7, Gemuk Group, Cinnabar Creek area; 8, Kuskokwim Basin, Taylor Mountains quadrangle; 9, Mulchatna subbasin of Kuskokwim Basin; 10, Southern Kahiltna terrane of Wallace and others, 1989; 11, Pebble Copper prospect; 12, Matanuska Formation; 13, Seldovia area; 14, Sitka area. 
that is commonly but not universally used in the detrital zircon research community. For three samples (04ATi103, 04ATi109, and $05 \mathrm{PH} 104 \mathrm{~b}$ ), we did not filter for discordance. These are young samples that expose a flaw of the 10 percent discordance filter, which in some populations wrongly discredits most zircons that are younger than about $200 \mathrm{Ma}$, even though they actually overlap concordia within error.

\section{Chugach Mountains}

The Chugach Mountains of south-central Alaska are largely underlain by a Mesozoic accretionary complex, the Chugach terrane (fig. 1B). This paper reports detrital zircon data from the two main components of the Chugach terrane: the McHugh Complex on the inboard side and the Valdez Group on the outboard side (fig. 2).

\section{McHugh Complex}

The McHugh Complex (Clark, 1973) is a structural assemblage, or mélange, of variably deformed and disrupted mafic volcanic rocks, gabbro, chert, graywacke, rare limestone, and rare ultramafic rocks - all in a phacoidally cleaved matrix of argillite and tuff. The McHugh Complex is characterized by moderate to intense stratal disruption, which resulted in tectonic juxtaposition of varied rock types at scales ranging from centimeters to kilometers (Bradley and Kusky, 1992). Previous age constraints on McHugh protoliths have mainly been provided by fossils and by isotope geochronology; contact relations are also locally helpful but it should be stressed that most dated rocks in the McHugh lack stratigraphic context because they are bounded by faults or shear zones. Permian fossil ages have been reported from a number of limestone bodies (Stevens and others 1997; Bradley and others, 1999) that are thought to represent decapitated seamounts. One fault-bounded gabbro body, at Halibut Cove in Seldovia quadrangle, yielded a concordant $\mathrm{U}-\mathrm{Pb}$ zircon age of $227 \mathrm{Ma}$ (Norian, Late Triassic; Kusky and others, 2007). None of the many basalts are directly dated, but cherts that depositionally overlie basalts range from Ladinian in the Middle Triassic to Albian-Aptian in the mid-Cretaceous (Bradley and others, 1999). At one location in the Seldovia quadrangle (locality 13 in fig. 1B), graywacke conformably overlies ribbon chert that yielded Pliensbachian (Early Juras-

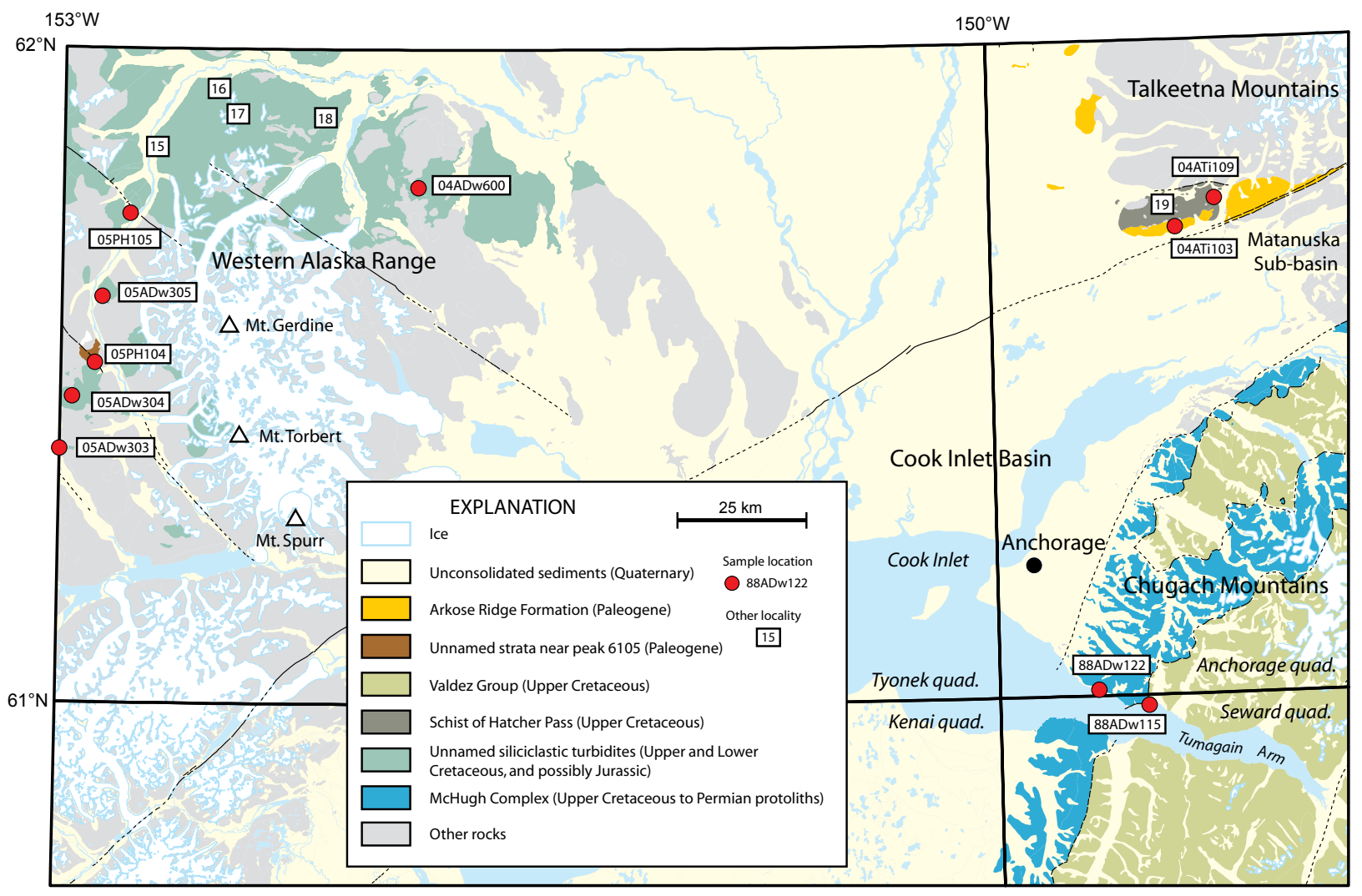

Figure 2. Simplified geologic map of parts of the Tyonek, Anchorage, Seward, and Kenai quadrangles, south-central Alaska, adapted from Wilson and others (2009). Locations of detrital zircon samples are shown by USGS sample number. Other localities mentioned in text are identified as follows: 15, Turonian bivalve occurrence; 16, Valanginian bivalve occurrence; 17 , Early Jurassic to Early Cretaceous radiolarian occurrence; 18, igneous clasts dated 95-101 Ma; 19, Grubstake Gulch. 
Table 1. Summary information for geochronology samples. Under Rock unit, map abbreviations correspond to those used by Wilson and others (2009).

\begin{tabular}{|c|c|c|c|c|c|c|c|}
\hline Field number & Quadrangle & Location & Rock unit & $\begin{array}{l}\text { Depositional } \\
\text { age of DZ } \\
\text { sample }\end{array}$ & $\begin{array}{l}\text { Igneous } \\
\text { age of } \\
\text { clast }\end{array}$ & $\begin{array}{l}\text { Latitude } \\
\text { (decimal } \\
\text { degrees) }\end{array}$ & $\begin{array}{l}\text { Longitude } \\
\text { (decimal } \\
\text { degrees) }\end{array}$ \\
\hline 05PH104B & Tyonek C8 & $\begin{array}{l}\text { Near Peak } \\
6105\end{array}$ & Tves & Eocene & NA & 61.520283 & -152.896770 \\
\hline 04ATi103 & $\begin{array}{l}\text { Anchorage } \\
\text { C7 }\end{array}$ & Arkose Ridge & $\begin{array}{l}\text { Arkose Ridge } \\
\text { Formation }\end{array}$ & Paleocene & NA & 61.710233 & -149.406416 \\
\hline 05PH105A & Tyonek C8 & $\begin{array}{c}\text { Emerald } \\
\text { Creek area }\end{array}$ & KJs & Coniacian & NA & 61.746383 & -152.803567 \\
\hline 04ATi109 & $\begin{array}{c}\text { Anchorage } \\
\text { D7 }\end{array}$ & Hatcher Pass & $\begin{array}{c}\text { Schist of } \\
\text { Hatcher Pass }\end{array}$ & Campanian & NA & 61.751316 & -149.282250 \\
\hline 88ADw122 & Seward D7 & Indian & Valdez Group & Campanian & NA & 60.982729 & -149.534971 \\
\hline 92AKu18 & $\begin{array}{l}\text { Seldovia } \\
\text { B2 }\end{array}$ & McCarty Fiord & Valdez Group & NA & $221 \pm 1 \mathrm{Ma}$ & 59.470277 & -150.473611 \\
\hline 88ADw115 & $\begin{array}{l}\text { Anchorage } \\
\text { A8 }\end{array}$ & Beluga Point & $\begin{array}{l}\text { McHugh } \\
\text { Complex }\end{array}$ & Turonian & $\begin{array}{c}179 \pm 3 \& \\
182 \pm 2 \mathrm{Ma}\end{array}$ & 61.006849 & -149.692504 \\
\hline 05ADW304A & Tyonek B8 & $\begin{array}{c}\text { N Fork } \\
\text { Chilligan } \\
\text { headwaters }\end{array}$ & Kes & Aptian & NA & 61.461560 & -152.972690 \\
\hline 05ADw305A & Tyonek C8 & $\begin{array}{c}\text { Crystal Creek } \\
\text { area }\end{array}$ & Kes & Aptian & NA & 61.619910 & -152.866580 \\
\hline 05ADW303C & Tyonek B8 & $\begin{array}{l}\text { Near Peak } \\
6140, \text { Max } \\
\text { Lake area }\end{array}$ & Kes & Hauterivian & NA & 61.390360 & -152.952710 \\
\hline 04ADW600A & Tyonek D5 & $\begin{array}{c}\text { Canyon Creek } \\
\text { area }\end{array}$ & Kes & $\begin{array}{l}\text { Valanginian } \\
\text { to } \\
\text { Hauterivian }\end{array}$ & NA & 61.796233 & -151.833383 \\
\hline
\end{tabular}

sic) radiolarians (Bradley and others, 1999). Regionally, graywacke has been considered to range in age from Pliensbachian through Early Cretaceous (Bradley and others, 1999; Winkler and others, 1981). Summarizing, various McHugh Complex protoliths have previously yielded reliable ages of Permian, Triassic, Jurassic, and Early Cretaceous; our results extend the age range to include the Late Cretaceous.

Along Turnagain Arm near Anchorage (fig. 2), the McHugh Complex consists of two informal subdivisions, an inboard and an outboard part. The inboard part is mainly mélange composed of fragments and disrupted beds of chert, mafic volcanic rocks, graywacke, and rare limestone and ultramafic rocks, set in a phacoidally cleaved matrix of argillite and tuff; this part of the McHugh Complex was not sampled for detrital zircons. The outboard part, which we sampled, is mostly siliciclastic rocks, including boulder and cobble conglomerate, graywacke, and argillite. Early in the course of regional mapping, Tysdal and Case (1977) considered the outboard part to be a separate unit from the McHugh Complex, but in a later reversal they included it as part of the McHugh Complex (Tysdal and Case, 1979).

Our samples of sandstone and igneous clasts are from a classic and much visited cliff exposure of the McHugh
Complex on the north side of the Seward Highway opposite the parking area at Beluga Point. This is Stop 3 of Bradley and Miller (2006). Most of the exposure is conglomerate (fig. 4A). Bedding is only locally observed and, even where visible, it generally cannot be traced far, because of disruption by faults and shear zones. The rocks have been metamorphosed to prehnite-pumpelleyite facies, as revealed by abundant contorted prehnite veinlets; thus the rocks record temperatures far below those required to reset zircon ages. Conglomerate clasts found here include argillite, greenstone, chert, sandstone, and granitic to gabbroic plutonic rocks (Fischietto and others, 2006); these are bonafide clasts and not blocks in mélange. Conodonts from a limestone cobble in conglomerate $2 \mathrm{~km}$ southeast of Beluga Point are Meramecian to Morrowan in age (Late Mississippian to Early Pennsylvanian; Nelson and others, 1986); this clast could have been shed from the Strelna Formation of the Wrangellia terrane (Nelson and others, 1986). A plutonic clast from a nearby outcrop yielded a hornblende K/Ar age of $146 \pm 7$ Ma (M.A. Lanphere, quoted in Clark, 1981). The geologic significance of this age is uncertain, owing to the very real possibilities of either excess argon or argon loss related to subduction metamorphism. 

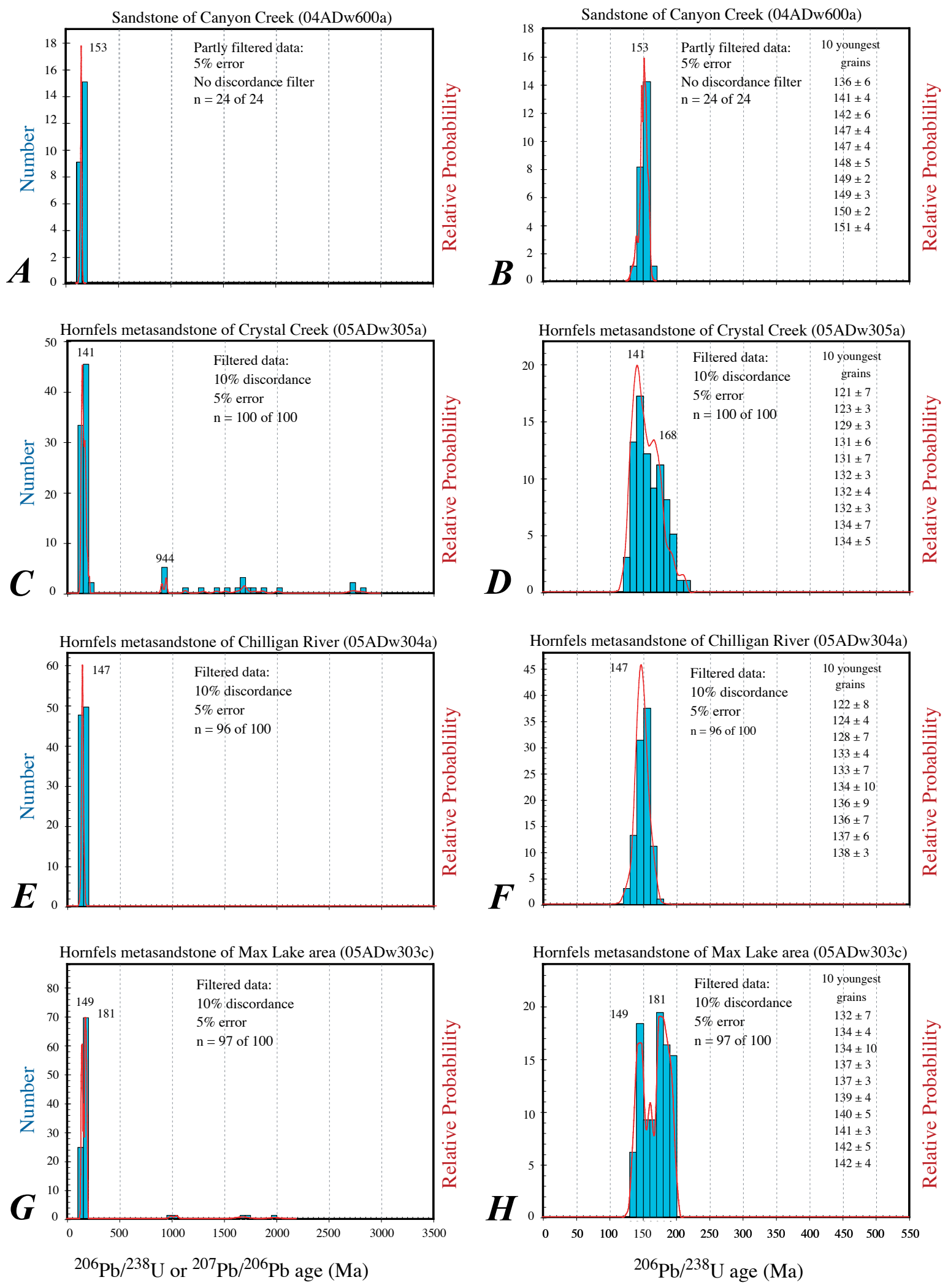

Figure 3. Histograms (blue boxes) and probability plots (red lines) of detrital zircon ages, filtered for discordance and analytical error as outlined in the text. Two plots are shown for each sample, one for 3500-0 Ma and a second one showing details for 550-0 $\mathrm{Ma}$. The plots are arranged to emphasize comparisons between samples of similar age. $A$ and $B$, Sample 04ADw600a, sandstone of the Canyon Creek area, western Alaska Range. C and D, Sample 05ADw305a, hornfels metasandstone of the Crystal Creek area, western Alaska Range. E and F, Sample 05ADw304a, hornfels metasandstone of the Chilligan River headwaters, 

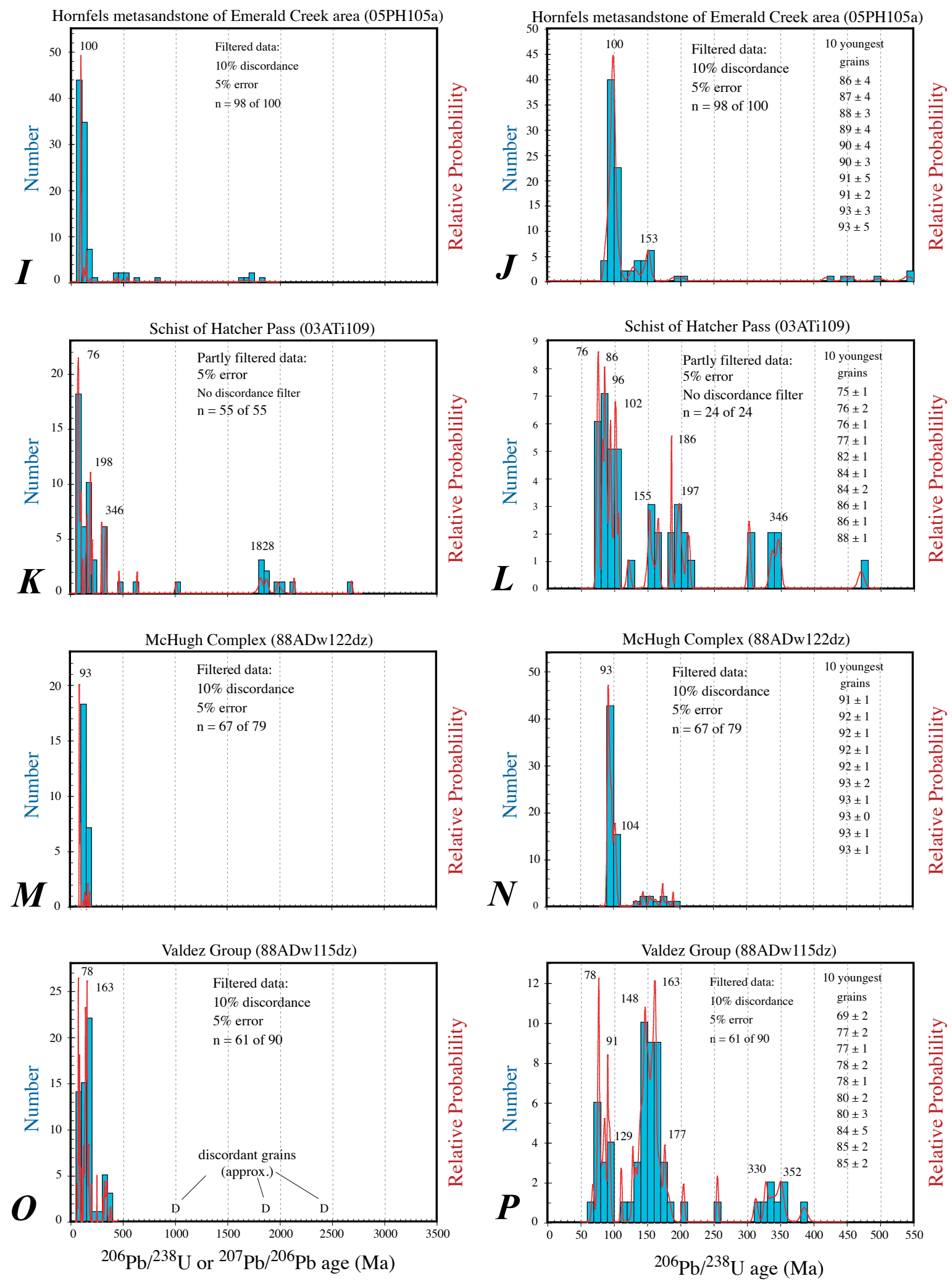

western Alaska Range. $G$ and $H$, Sample 05ADw303c, hornfels metasandstone of the Max Lake area, western Alaska Range. I and $J$, Sample 05PH105a, hornfels metasandstone of the Emerald Creek area, western Alaska Range. Kand L, Sample 04AT1109 schist of Hatcher Pass, Talkeetna Mountains. $M$ and $N$, Sample 88ADw122dz, McHugh Complex, Chugach Mountains. $O$ and $P$, Sample 88ADw115dz, Valdez group, Chugach Mountains. $Q$ and $R$, Sample 05PH104b, hornfels metasandstone of the Peak 6105 area, western Alaska Range. $S$ and $T$, Sample 04ATi103, Arkose Ridge Formation, Talkeetna Mountains. 


\section{Geochronology of Igneous Clasts}

$\mathrm{U}-\mathrm{Pb}$ zircon ages were obtained on two similar diorite clasts from conglomerate at Beluga Point using the U.S. Geological Survey (USGS)-Stanford SHRIMP-RG at Stanford University using methods detailed in the appendix. Both clasts are greenish gray, coarse grained diorite containing greenish altered plagioclase, hornblende, and pyroxene. The ages are almost identical, at $181.8 \pm 2.1$ and $179.2 \pm 2.8 \mathrm{Ma}$ (fig. 5A and B) (samples 88ADw122x and 88ADw122w in Table 1). The ages of these clasts match the zircon ages of arc plutons in the northern Chugach Mountains (for example, $181.4 \pm 1.0$ and $181.5 \pm 0.3 \mathrm{Ma}$ ), and in the southern Talkeetna
Mountains (for example, 177.5 $\pm 0.8 \mathrm{Ma}$ ) (Rioux and others, 2007). Fischetto and others (2006) proposed a similar link between plutonic clasts from Beluga Point and Mesozoic arc rocks, on the basis of geochemistry.

\section{Detrital Zircons}

The detrital zircon sample (88ADw122dz) is from a zone of coarse sandstone within the predominantly conglomeratic outcrop at Beluga Point. U-Pb ages were obtained for 79 detrital zircon grains. The histogram and probability density curve show two peaks, one in the Late Cretaceous (93 Ma)
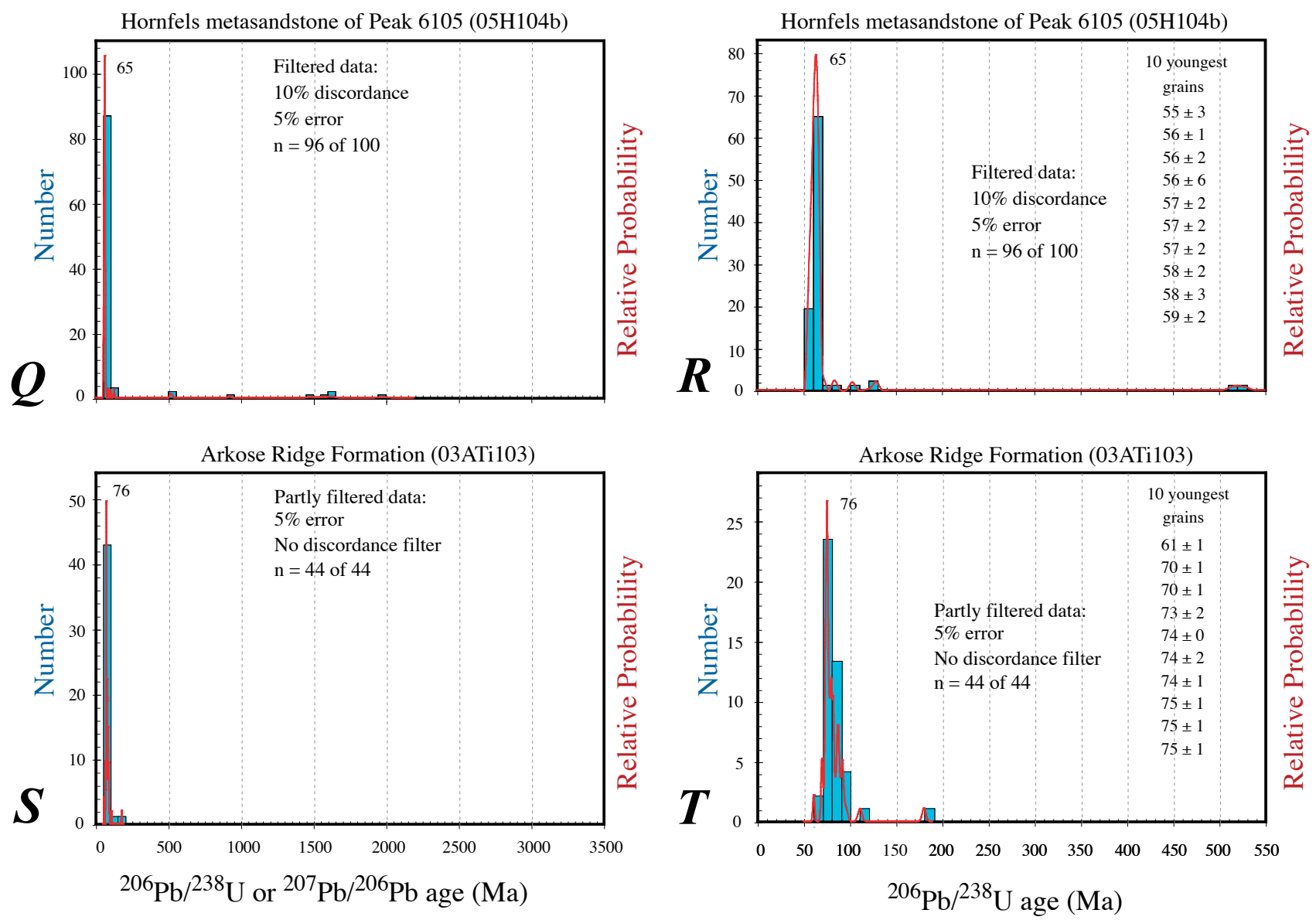

Figure 3. Histograms (blue boxes) and probability plots (red lines) of detrital zircon ages, filtered for discordance and analytical error as outlined in the text. Two plots are shown for each sample, one for 3500-0 Ma and a second one showing details for 550-0 Ma. The plots are arranged to emphasize comparisons between samples of similar age. $A$ and $B$, Sample 04ADw600a, sandstone of the Canyon Creek area, western Alaska Range. $C$ and D, Sample 05ADw305a, hornfels metasandstone of the Crystal Creek area, western Alaska Range. E and F, Sample 05ADw304a, hornfels metasandstone of the Chilligan River headwaters, western Alaska Range. $G$ and $H$, Sample 05ADw303c, hornfels metasandstone of the Max Lake area, western Alaska Range. I and J, Sample 05PH105a, hornfels metasandstone of the Emerald Creek area, western Alaska Range. $K$ and L, Sample 04ATi109 schist of Hatcher Pass, Talkeetna Mountains. $M$ and $N$, Sample 88ADw122dz, McHugh Complex, Chugach Mountains. $O$ and $P$, Sample 88ADw115dz, Valdez group, Chugach Mountains. $Q$ and $R$, Sample 05PH104b, hornfels metasandstone of the Peak 6105 area, western Alaska Range. S and T, Sample 04ATi103, Arkose Ridge Formation, Talkeetna Mountains.-Continued. 


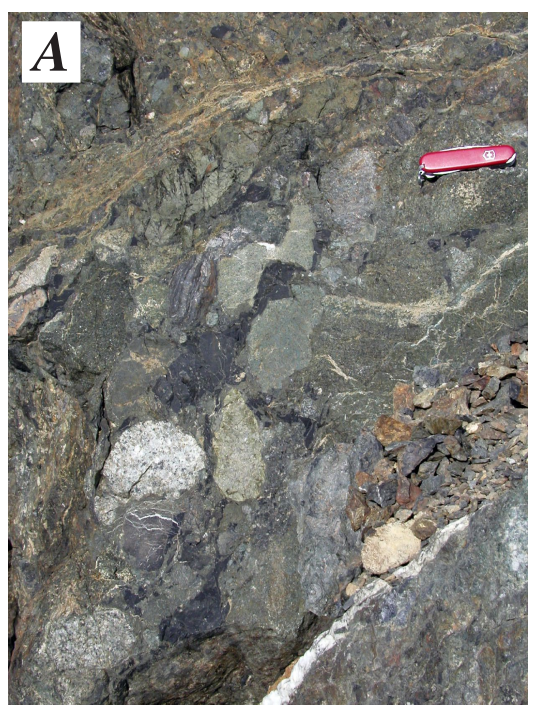

88ADw122

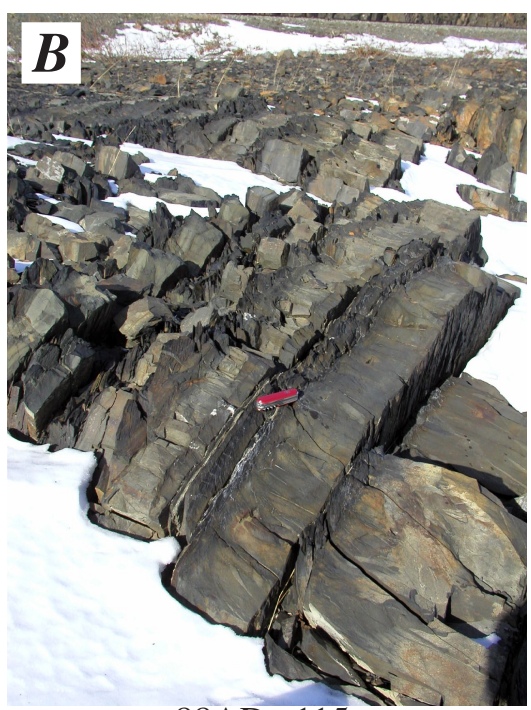

88ADw115

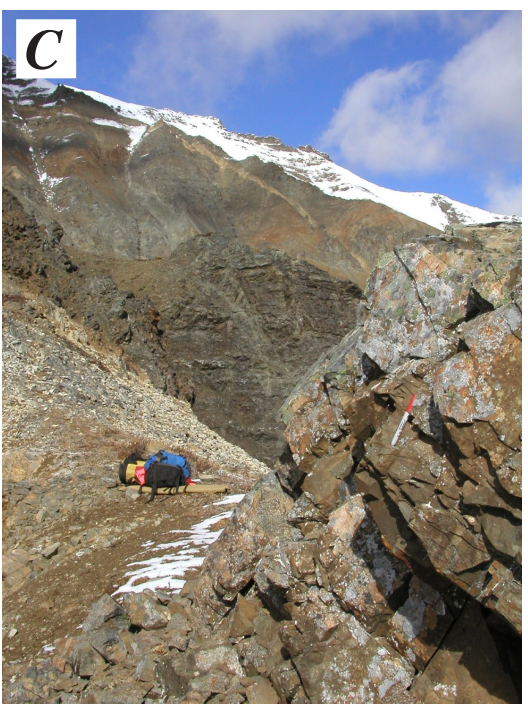

05ADw304

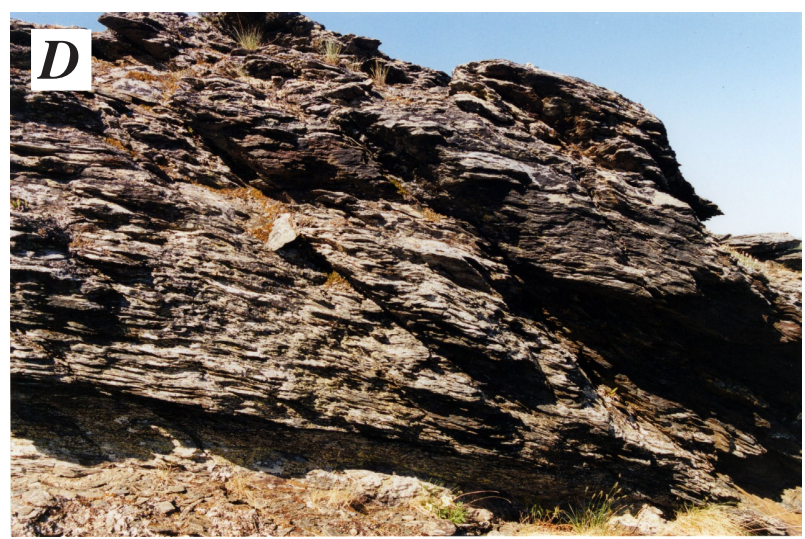

04ATi109

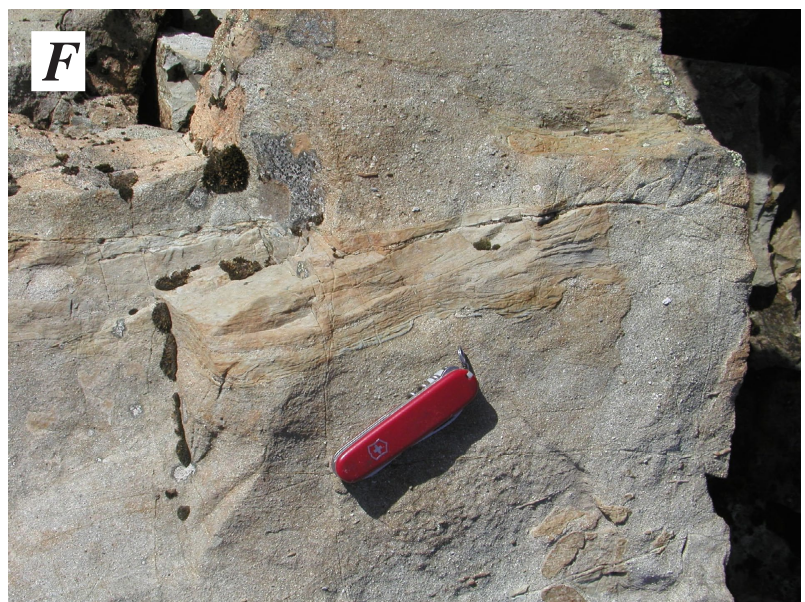

04ADw600

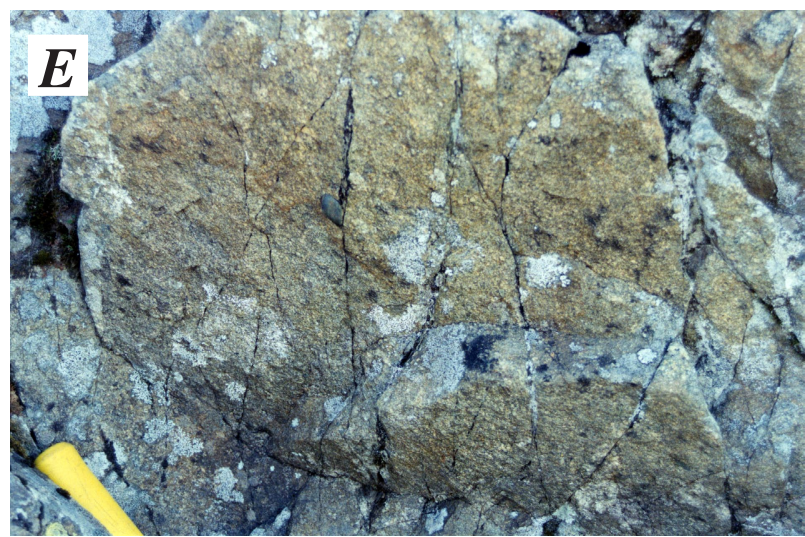

04ATi103

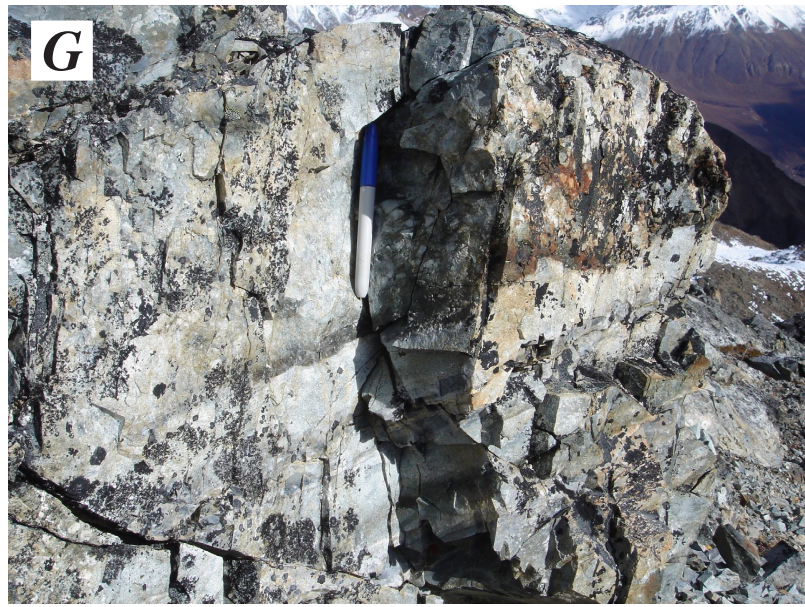

05PH104b

Figure 4. Outcrop photographs of rock units sampled for geochronology. $A, 88 \mathrm{ADw} 122$, McHugh Complex, Upper Cretaceous conglomeratic metasandstone. B, 88ADw115, Valdez Group, Upper Cretaceous sandstone. C, 04ATi109, schist of Hatcher Pass, Upper Cretaceous. D, 04ATi103, Arkose Ridge Formation, Paleogene. E, 03ADw600, sandstone of the Canyon Creek area, Lower Cretaceous. F, 05ADw304, hornfels metasandstone of the Chilligan River headwaters, Lower Cretaceous. G 05PH104, hornfels metasandstone of the Peak 6105 area, Paleogene. 
and one in the Late Jurassic (162 Ma) (figs. 3M and N). Of the 79 grains, 9 are Jurassic, 16 are Early Cretaceous, 42 are Late Cretaceous, and the remainder did not pass the filters. Jurassic grains at 182 and 175 are close matches for the dated igneous clasts. Older Paleozoic and Precambrian grains are completely lacking.

The probability plot is dominated by a peak at $93 \mathrm{Ma}$ (fig. $3 \mathrm{~N}$ ). The 10 youngest grains are barely younger than

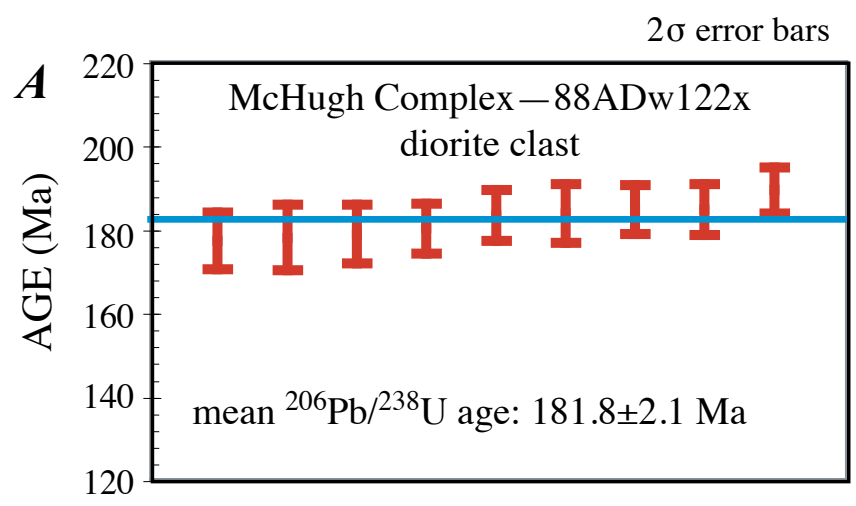

$2 \sigma$ error bars
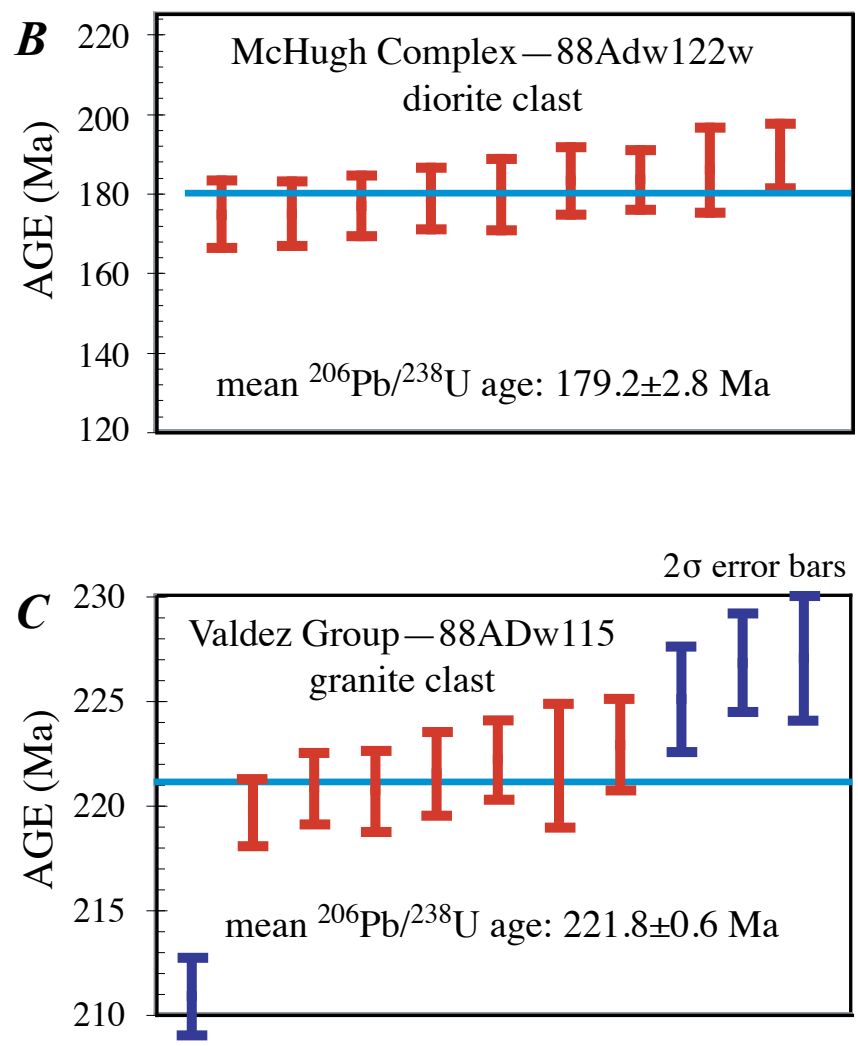

Figure 5. Individual ${ }^{206} \mathrm{~Pb} / 238 \mathrm{U}$ ages of zircon grains from igneous clasts from $(A, B)$ the McHugh Complex and $(C)$ the Valdez Group, plotted using the TuffZirc subroutine of the Isoplot Excel macro of Ludwig (2003). Deep purple bars are analyses that were excluded from the mean calculation. this, ranging from $93 \pm 2$ to $91 \pm 2 \mathrm{Ma}$. The sandstone and conglomerate of the McHugh Complex was previously regarded as mid-Cretaceous (Winkler and others, 1981). We can now refine the age to no older than 93-91 Ma, and we suggest that it is probably about the same age as the youngest zircons, Turonian (Late Cretaceous). The McHugh sandstone appears to have been derived solely from a Mesozoic arc, one that was active during Turonian deposition and had been intermittently active at least as far back as Early Jurassic time.

The refined age assignment for this part of the McHugh Complex implies that it is the same age as much of the vast Kuskokwim Group of southwestern Alaska (Box and Elder, 1992). The detrital zircon signature of the Kuskokwim shares some common features with the detrital zircon barcode of the McHugh Complex: both contain abundant Cretaceous and Jurassic zircons (Miller and others, 2007a). The Kuskokwim differs profoundly from the McHugh, however, in containing a broad mix of Precambrian grains.

\section{Valdez Group}

The seaward part of the Chugach terrane is underlain by the Valdez Group of Campanian to Maastrichtian (Late Cretaceous) age. Age control is based on a handful of inoceramid bivalves (Tysdal and Plafker, 1978; Plafker and others, 1994). The Valdez Group includes thick-, medium-, and thin-bedded graywacke turbidites, dark gray slate, and minor pebble to cobble conglomerate. Sandstones of the Valdez Group generally are moderately well sorted and consist mostly of quartz and feldspar, some volcanic fragments, and rare chert (Dumoulin, 1987). Where no structural complications are apparent in the Seldovia quadrangle, Bradley and others (1999) estimated a minimum stratigraphic thickness of $6.5 \mathrm{~km}$. Most of the Valdez Group consists of relatively coherent strata that were deformed into regional-scale tight to isoclinal folds and cut by a slaty cleavage. The Valdez Group is juxtaposed with the McHugh Complex across a regional-scale thrust fault, which in the area of Turnagain Arm is called the Eagle River Fault. Beneath the fault is a monomict mélange of partially to thoroughly disrupted Valdez Group turbidites - the informally named Iceworm mélange of Kusky and others (1997). The Valdez Group was probably deposited on the downgoing plate in a deep-sea trench (Nilsen and Zuffa, 1982) and accreted shortly thereafter.

\section{Geochronology of an Igneous Clast}

$\mathrm{A}$ U-Pb zircon age was obtained from a clast of granite in a Valdez Group conglomerate (92AKu18; table 1). The analysis was done on the USGS-Stanford SHRIMP-RG. The conglomerate crops out on the outer coast of the Kenai Peninsula in Seldovia quadrangle (figs. 1A, 6). A massive sandstone at this location contains isolated, matrix-supported, 
rounded granitic cobbles. The granite is fine-grained, pinkish tan, nonfoliated, leucocratic, and contains quartz, plagioclase, potassium feldspar, and rare muscovite. Single-crystal analyses of zircons from the granite clast yielded $\mathrm{a}^{206} \mathrm{U} /{ }^{238} \mathrm{~Pb}$ age of $221.0 \pm 1.4 \mathrm{Ma}$ (fig. 5C). The age is the mean of the seven overlapping analyses that are concordant within 2 sigma. The zircons have consistently high concentrations of uranium and thorium, with mean values of 1972 and 1045 ppm, respectively.

\section{Detrital Zircons}

The detrital zircon sandstone sample was collected from the classic, wave-washed exposures of Valdez Group near Indian along Turnagain Arm (figs. 2 and 4B). This is Stop 4 of Bradley and Miller (2006). This outcrop is unusual in the clarity of the preserved sedimentary structures but is typical of Valdez Group lithologies including thin- and medium-bedded Bouma sequences of sandstone grading to slate, and medium-

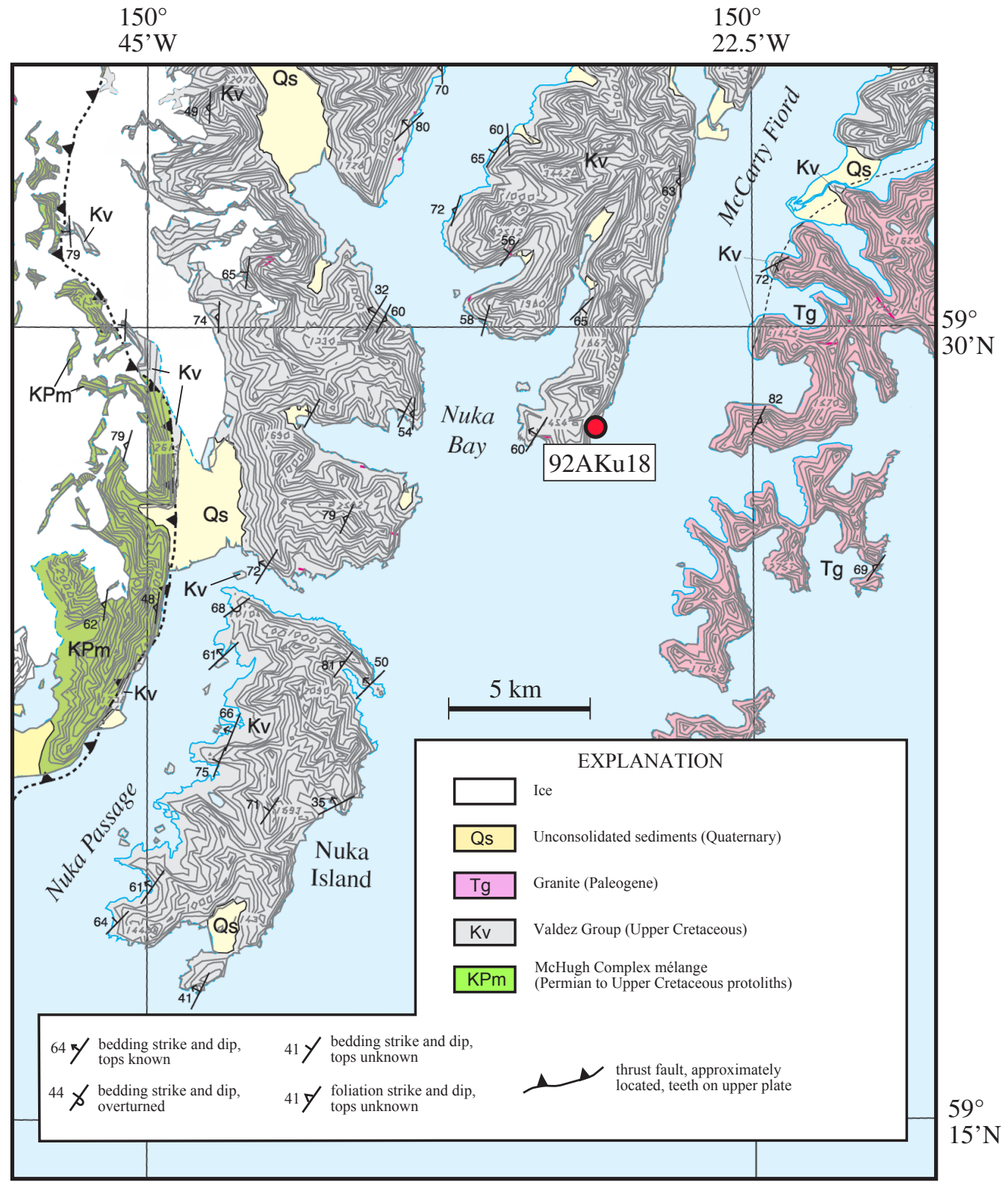

Figure 6. Geologic map of the Nuka Bay area, Seldovia quadrangle, showing the location of the igneous clast (92AKu18) from the Valdez group. From Bradley and others (1999). 
to very coarse grained channel sandstones and pebble conglomerate. Paleocurrents from turbidite cross laminae at this locality are toward the southwest (Bradley and others, 2003).

$\mathrm{U}-\mathrm{Pb}$ ages were obtained for 90 detrital zircon grains from sample $88 \mathrm{ADw} 115 \mathrm{dz}$. The histogram and probability density curve show a peak in the Late Cretaceous (78 Ma) and two peaks in the Jurassic (148 and $162 \mathrm{Ma}$ ) (fig. $3 \mathrm{O}$ and P). Of the 90 grains, 1 is Devonian, 7 are Carboniferous, 1 is Permian, 1 is Triassic, 29 are Jurassic, 8 are Early Cretaceous, and 13 are Late Cretaceous. The remaining grains did not pass the 10 percent discordance filter, but, whether they are discordant owing to lead loss or inheritance, 3 must be Precambrian, at ca. 2.4, 1.8 , and $1.0 \mathrm{Ga}$ (Table 2). The 10 youngest grains range from $85 \pm 2$ to $69 \pm 2 \mathrm{Ma}$. Our detrital zircon results from the Valdez Group are consistent with the Campanian to Maastrichtian (Late Cretaceous) age suggested by sparse fossils (Plafker and others, 1994). The youngest grain, at $69 \pm 2 \mathrm{Ma}$, is concordant, but it is a single grain; the next four youngest grains are 78-77 Ma.

The present results are broadly comparable with some detrital zircon results from the Sitka Graywacke of southeast Alaska (Haeussler and others, 2006), which has long been regarded as a correlative of the Valdez Group. Samples taken along an across-strike transect near Sitka (locality 14 in fig. 1B) define a younger western part of the unit, and an older eastern part. In four samples from the western part, the means of the 10 youngest grains are $72,72,70$, and $6972 \mathrm{Ma}$. If (as seems likely) the youngest grains in the western Sitka Graywacke and Valdez Group are very close to the respective depositional ages, these parts of the two rock units are close to the same age. In three samples from the eastern part of the Sitka Graywacke, the means of the 10 youngest grains are 102, 101, and $93 \mathrm{Ma}$. The eastern Sitka Graywacke thus appears to be older than our Valdez Group sample, and partly overlaps the age of our McHugh Complex sample.

\section{Southern Talkeetna Mountains}

\section{Schist of Hatcher Pass}

The informally named schist of Hatcher Pass crops out in a 6-by-16-km belt just north of the southwestern end of the Talkeetna Mountains (fig. 2). It is quite distinct from any other bedrock unit in the region, as Capps (1915) recognized nearly a century ago. Most of this belt is underlain by greenschist-facies schist (fig. 4D). The belt also includes several small, metamorphosed mafic-ultramafic slivers or lozenges that are the same metamorphic grade as the schists, and were likely tectonically interleaved with the protoliths of the schists before or during metamorphism. A metagabbro from this suite was sampled for zircon geochronology, but was barren, and the age of the mafic-ultramafic rocks remains unknown. The schist is bounded on the north by granitic rocks of the 73 to 67
Ma (Harlan and others, 2003) Willow Creek batholith across an east-west, high-angle fault. It is bounded on the south by conglomerate of the Paleocene-Eocene Arkose Ridge Formation across what has been previously mapped as an angular unconformity, but in fact is a low-angle detachment fault (A. Till and D. Bradley, unpublished mapping).

Previous assessments of the ages of the protolith and of the metamorphism have been sketchy and speculative. On the assumption that the Hatcher Pass schist shared a metamorphic history with Jurassic amphibolites to the northeast, the schist was assigned a Jurassic age of prograde metamorphism by Csejtey and others (1978), and this age assignment was adopted on the Geologic Map of the Anchorage quadrangle (Winkler, 1992, his Unit Jps). Conventional K-Ar muscovite ages of 66-55 Ma were attributed not to peak syntectonic metamorphism, but instead to the heat from Late Cretaceous plutons to the north (Csejtey and others, 1978; Winkler, 1992). Harlan and others (2003) confirmed and refined the Paleogene metamorphic ages using the ${ }^{40} \mathrm{Ar} /{ }^{39} \mathrm{Ar}$ method (61 to 57 Ma). Van Wyck and Norman (2005) reported the ages of 34 individual zircons from unconsolidated sediments at the gold placer in Grubstake Gulch (locality 19 in fig. 2), which drains an area almost entirely underlain by schist, plus minor mafic/ ultramafic bodies. Van Wyck and Norman (2005) suggested that some of their zircons had been eroded out of local bedrock sources, whereas some zircons were from more distant sources. They reported age clusters at 2500-2442, 548-350, $210-160,104-87$, and 79-59 Ma. According to their interpretation, the three oldest age clusters represent detrital zircons eroded out of the schist of Hatcher Pass, to which they accordingly assigned a Late Jurassic depositional age. They interpreted the mid-Cretaceous age cluster (104-87 Ma) as having been derived from serpentinite bodies. They interpreted their youngest age cluster as having been transported (presumably by ice) into Grubstake Gulch from Late Cretaceous plutons just to the north. Our zircon data suggest a new interpretation.

$\mathrm{U}-\mathrm{Pb}$ ages were obtained from 59 detrital zircons from sample 04ATi109 (Table 1) using the USGS-Stanford SHRIMP-RG (table 2). The schist has a strong, gently to moderately dipping foliation and no surviving vestige of bedding (fig. 4D). In thin section, quartz, white mica, and chlorite define foliation and deflect around porphyroblasts of garnet and albite. A mineral separate yielded abundant, 100200 micron, rounded zircons having a variety of ages, which, together with the semipelitic to pelitic lithologies, confirm a mixed sandstone-shale protolith. The detrital zircons range in age from 2692 to $75 \mathrm{Ma}$. Of the 59 grains, 1 is Archean, 9 are Paleoproterozoic, 4 are Mesoproterozoic, 1 is Neoproterozoic, 1 is Ordovician, 6 are Carboniferous, 3 are Triassic, 10 are Jurassic, 6 are Early Cretaceous, and 18 are Late Cretaceous. The probability density curve shows four distinct Cretaceous peaks from 102 to $76 \mathrm{Ma}$, a pair of Late Jurassic peaks at 166 and $155 \mathrm{Ma}$, three Late Triassic to Early Jurassic peaks at 213, 197 , and $186 \mathrm{Ma}$, and minor Carboniferous peaks at 346 and $303 \mathrm{Ma}$ (figs. 3K, L). 
Combining the new detrital zircon geochronology with the ${ }^{40} \mathrm{Ar} /{ }^{39} \mathrm{Ar}$ metamorphic geochronology of Harlan and others (2003), there is no question now that the sedimentary protolith of the schist of Hatcher Pass is Late Cretaceous to Paleocene in age. Specifically, it must have been deposited between ca. $61 \mathrm{Ma}$ (the age of peak metamorphism) and 77-75 Ma (the age range of the four youngest zircons). We favor a depositional age close to the age of the youngest zircons, Campanian (Late Cretaceous).

The Hatcher Pass zircons have a surprisingly diverse mix of ages, reminiscent of other Upper Cretaceous strata in from at least four sedimentary sequences in Alaska. Miller et al. (2007a) reported detrital zircon data from the Kuskokwim Group of southwestern Alaska (locality 8 in fig. 1B). The main statistical peaks of a composite (multi-sample) Kuskokwim Group barcode are at 1987, 350, 187, and 93 $\mathrm{Ma}$, and lesser peaks are at 1822 and $1122 \mathrm{Ma}$ (Miller and others, 2007a). The Upper Cretaceous Minto Unit of the Manley Basin, Livengood quadrangle (locality 1 in fig. 1B; Weber and others, 1992), has probability peaks at 1847 , 1074, 188, and $94 \mathrm{Ma}$ (D. Bradley, A. Till, and R. Friedman, unpublished data, 2007). The Albian to Campanian (Upper Cretaceous) Caribou Pass Formation of the Kahiltna basin, Healy quadrangle (locality 4 in fig. 1B) has probability peaks at 353,192, and $82 \mathrm{Ma}$, and a few Paleoproterozoic and Archean zircons (Hampton and Sunderlin, 2008). Finally, as shown in figure 3P, the Valdez Group has major probability peaks at 163,148, 91, and $78163 \mathrm{Ma}$, and lesser peaks at 352 and $330 \mathrm{Ma}$. (As noted previously, the Valdez Group sample also yielded Precambrian grains at ca. 1.0, 1.8, and $2.4 \mathrm{Ga}$, but these did not pass the 10 percent discordance filter.) This topic is developed further in the section on "Tectonic Implications."

\section{Arkose Ridge Formation}

The Arkose Ridge Formation crops out along the northern margin of the Cook Inlet-Matanuska forearc basin (fig. 2). It has a thickness of at least $1,600 \mathrm{~m}$ and consists mostly of arkosic conglomerate and sandstone and subordinate mudstone, coal, tuff, and basalt (Trop and Ridgway, 2002) (fig. 4E). The age ranges from Late Paleocene to Middle Eocene (Trop and Ridgway, 2002). A tuff from the Arkose Ridge Formation yielded a late Paleocene $\mathrm{U}-\mathrm{Pb}$ zircon age of $57.9 \pm 0.5 \mathrm{Ma}$ ( 2 concordant fractions; R. Friedman and D. Bradley, unpublished data).

$\mathrm{U}-\mathrm{Pb}$ ages were obtained from 44 detrital zircons from sample 04ATi103 using the USGS-Stanford SHRIMP-RG. Detrital zircons were analyzed from a coarse, pebbly sandstone containing angular grains of quartz, two feldspars, and detrital biotite and hornblende. The barcode is relatively simple, with a dominant Late Cretaceous peak at $76 \mathrm{Ma}$, and minor ones at 92, 88, 80, and $70 \mathrm{Ma}$ (fig. 3S). One Early Jurassic, 1 Early Cretaceous and 1 Paleocene zircon were found in this relatively small population; all other grains are Late Cretaceous.

On geologic grounds alone, it is clear that the Arkose Ridge Formation was derived from the Talkeetna Mountains to the north (Trop and Ridgway, 2002). Our detrital zircon data show that the source area was a portion of the Talkeetnas almost entirely underlain by Late Cretaceous plutons. Four U-Pb dates are available from plutonic phases of the Willow Creek batholith a few $\mathrm{km}$ to the north of the Arkose Ridge sample $(72.5 \pm 0.4,71.9 \pm 0.3,70.5 \pm 0.2$, and $67.3 \pm 0.2 \mathrm{Ma}$; Harlan and others, 2003 $)^{10}$. These plutonic ages are all younger than the 76-Ma probability peak in the detrital zircon barcode, but it should be remembered that the Willow Creek batholith is huge and many phases have yet to be sampled for modern geochronology. The Arkose Ridge detrital zircon sample probably more fully captures the complete range of Late Cretaceous plutonism in the Talkeetna Mountains. This peak is a hallmark of forearc strata in the Matanuska subbasin: the dominant peak for sandstone samples from the Upper Cretaceous Matanuska Formation, Paleocene Chickaloon Formation, and Oligocene Tsadaka Formation is 76-74 Ma (Trop, 2008; Trop and Bradley, unpublished data). Thus, Late Cretaceous arc rocks were an important sediment source throughout Cretaceous-Paleogene time for sediments exposed in both the forearc and accretionary prism.

\section{Western Alaska Range}

The western Alaska Range in the Tyonek quadrangle (fig. 2 ) is mainly underlain by Lower Cretaceous and younger sedimentary and volcanic rocks, including the still-active Mt. Spurr volcano, and by intrusive rocks ranging in age from 98 to 36 Ma. The 98- to 36-Ma plutons were emplaced into a belt of siliciclastic turbidites, which are little studied and not formally named. Reed and Elliott (1970) originally assigned these strata to two groups of units: Cretaceous metasedimentary rocks (their Units $\mathrm{Km}$ and $\mathrm{Kw}$ ) and pre-Cretaceous metasedimentary and metavolcanic rocks (their Units Mzm, Mzv, and Mzu). On their compilation map of Alaskan terranes, Silberling and others (1994) showed the northwestern Tyonek quadrangle as being entirely underlain by their Kahiltna terrane. Later, Wilson and others (1998) assigned the same strata to Units JPzk and KJf, essentially following Reed and Elliott (1970) but with slightly different age assignments and map abbreviations. The results reported here, from samples collected between 2002 and 2005, have suggested various changes to these previous rock-unit assignments. The detrital zircon age constraints have been accounted for in the latest geological compilation of the Cook

\footnotetext{
${ }^{10}$ Note added in proof: new unpublished SHRIMP-RG U-Pb ages were obtained from plutonic rocks in the area immediately north of the Arkose Ridge Formation sample (H. Bleick and D. Bradley, unpublished data, 2009). New ages of $79.1 \pm 1.0,76.1 \pm 0.9$, and $75.8 \pm 0.7 \mathrm{Ma}$ were obtained from the Willow Creek batholith. In addition, an age of $90.3 \pm 3$ Ma was obtained from diorite in what was erroneously assigned to Unit Jma by Winkler (1992).
} 
Inlet region by Wilson and others (2009), from which Figure 2 was simplified. The various samples are from rocks shown on that map as Units KJs, Kes, and Tves. More refinements will eventually be needed as more of these monotonous looking strata are dated and correlated using detrital zircons.

Before the present study, age control for turbidites of the northwestern Tyonek quadrangle was provided by a smattering of fossils, by intrusive relations of a few cross-cutting plutons of known age, and by ages of conglomerate clasts. The fossils include a Turonian bivalve (locality 15 in fig. 2) ${ }^{11}$, a Valanginian bivalve (locality 16 in fig. 2) ) $^{12}$, and Early Jurassic to Early Cretaceous radiolarians (locality 17 in fig. 2) ${ }^{13}$. Layer (in Solie and others, 1991) obtained ${ }^{40} \mathrm{Ar} /{ }^{39} \mathrm{Ar}$ hornblende plateau ages of $101.0 \pm 0.7,95.3 \pm 1.1$, and $94.6 \pm 1.5$ from individual clasts from a conglomerate (locality 18 in fig. 2), providing further evidence for the presence of strata that are younger than Early Cretaceous.

Additional age control is hinted at by extrapolation from areas to the northeast and southwest. To the immediate north in the Talkeetna quadrangle (fig. 1) is a vast area mapped by Reed and Nelson (1980) as their Unit KJs. This corresponds to the informally named Kahiltna assemblage (or Kahiltna sequence or Kahiltna terrane), which extends to the north and east into the McGrath, Mt. McKinley, Talkeetna Mountains, and Healy quadrangles (fig. 1) and ranges in age from Late Jurassic (Kimmeridgian) to Late Cretaceous (Cenomanian) (Trop and Ridgway, 2007). The Kahiltna assemblage has also been traced along strike to the south as far as the Lake Clark and Taylor Mountains quadrangles (locality 10 in fig. 1B), where Wallace and others (1989) assigned the Koksetna River sequence to what they called the southern Kahiltna terrane. These rocks have yielded Late Jurassic (Kimmeridgian) to Early Cretaceous (Valanginian) bivalves.

To the west of the Tyonek quadrangle, in the Lime Hills, Taylor Mountains, and Sleetmute quadrangles (fig. 1), lies the Kuskokwim basin of Upper Cretaceous turbidites. Strata of the eastern arm of the Kuskokwim basin (Mulchatna subbasin of Box and Elder, 1992) (locality 9 in fig. 1B) strike roughly into the Tyonek quadrangle, although intervening plutons interrupt what once might have been direct connections. The two known

\footnotetext{
${ }^{11}$ During the course of mineral exploration in 1989, a coquina bed was collected in unnamed Mesozoic turbidites by Madelyn Millholland. The sample was designated $\mathrm{F} 1$ and the approximate location was given as $61.88333^{\circ} \mathrm{N}$, $152.58333^{\circ} \mathrm{W}$, lower Chickak River area. In 1989 , the sample was submitted (as shipment number A-89-4M) for identification by D. Bradley to Will Elder of the U.S. Geological Survey. He identified the bivalves as Buchia sublaevis of Early Cretaceous, Valanginian age.

${ }^{12}$ During the course of mineral exploration in 1989, a bivalve was collected in unnamed Mesozoic turbidites by Madelyn Millholland. The sample was designated F2 and the approximate location was given as $61.85000^{\circ} \mathrm{N}, 152.21666^{\circ} \mathrm{W}$, Skwentna River between Emerald and Muddy Creeks. In 1989, the sample was submitted (as shipment number A-89-4M) for identification by D. Bradley to Will Elder of the U.S. Geological Survey. He identified the bivalve as Inoceramus hobetsensis of Late Cretaceous, Middle Turonian age.

${ }^{13}$ The sample, number 06SWN50, is radiolarian chert, collected in 2006 by Steve Nelson. The sample was float in a cirque mainly underlain by turbidites, and is unlikely to have moved far from its original outcrop (S.W. Nelson, oral commun., 2006). Radiolarians were identified by E. Pessagno (written commun. to M.L. Miller, 2006).
}

fossil localities in the Mulchatna subbasin are both Cenomanian to Turonian (ca. 100 to $89 \mathrm{Ma}$ ) (Box and Elder, 1992).

The turbidites of the northwestern Tyonek quadrangle thus occupy a place where the Kahiltna, Kuskokwim, and Koksetna depositional basins might be expected to meet or overlap. Detrital zircon results are reported below for six samples in this area. As will be shown, depositional ages are inferred to include Early Cretaceous (4 samples), Late Cretaceous (1 sample), and - surprisingly—Paleogene (1 sample).

\section{Sandstone of the Canyon Creek Area- Valanginian to Hauterivian}

The oldest detrital zircon sample (04ADw600a) is from a chalky weathering, green, volcaniclastic sandstone that crops out in the eastern foothills of the Alaska Range (fig. 2 ). In the compilation of Wilson and others (1998), these rocks were assigned to Unit KJf; in light of the detrital zircon ages reported herein, Wilson et al. (2009) assigned these rocks to their Unit Kes. The sample location is at an old helicopter crash site (twisted rotor blades are all that remain) on a rounded hilltop in the upper reaches of Canyon Creek, Tyonek D-5 quadrangle. The rocks are unmetamorphosed and at the sample site dip $19^{\circ}$ to the north. The sample location is within an intact, gently to moderately dipping stratigraphic succession of feldspathic sandstone and lesser siltstone (fig. 4F) that can be followed northward for at least $1 \mathrm{~km}$ and is several hundred meters thick. The detrital zircon sample is a poorly sorted, coarse sandstone containing angular clasts of quartz, plagioclase, potassium feldspar, chlorite, and intermediate volcanic rocks.

Zircons in sample 04ADw600a are generally euhedral and clear. Twenty-four grains were dated, which range in age from 160 to $136 \mathrm{Ma}$ (figs. 3A, B; table 2). Paleozoic and Precambrian zircons are notably absent. The statistical peak in the probability density plot is at $153 \mathrm{Ma}$ (Late Jurassic), and the depositional age must be younger still. More than half of the grains are younger than the 153-Ma peak, and the three youngest grains, dated $142 \pm 6,141 \pm 4$, and $136 \pm 6 \mathrm{Ma}$ are Early Cretaceous. Accordingly, we assign an Early Cretaceous, Valanginian to Hauterivian depositional age to this sample; we reason that the depositional age is probably close to the age of the youngest zircons, as is typically the case for syntectonic sandstones deposited along convergent margins. The zircons were derived from a magmatic arc, presumably the Wrangellia composite terrane.

\section{Hornfels Metasandstone of the Chilligan River Headwaters-Aptian}

Sample 05ADw304a is from an outcrop area of hornfels in the northern headwaters of the Chilligan River in north- 
western Tyonek B-8 quadrangle (fig. 2). These rocks were assigned to Unit Mzs by Reed and Elliott (1970), then to Unit JPzk in the compilation by Wilson and others (1998). In light of the detrital zircon ages reported herein, Wilson et al. (2009) assigned these rocks to their Unit Kes. The sample is from an outcrop of moderately dipping, weakly contact metamorphosed, coarse sandstone (fig. 4C) containing angular detrital grains of quartz, feldspar, chlorite, epidote, and rock fragments of chert and siltstone. At the sample site, the beds dip 55 degrees NNW and the younging direction is unknown.

Detrital zircons were analyzed by Apatite to Zircon, Inc., at Washington State University. The detrital zircons range in age from 172 to $122 \mathrm{Ma}$. Of 100 grains, 69 are Jurassic, 27 are Cretaceous, and 4 did not pass the filters. Paleozoic and Precambrian grains are absent. The probability density curve shows a lone Late Jurassic peak at $152 \mathrm{Ma}$ (figs. 3E, F; table 2 ). The depositional age must be somewhat younger than this peak, because 66 grains are younger. The three youngest grains, dated $128 \pm 7,124 \pm 4$, and $122 \pm 8 \mathrm{Ma}$, are Early Cretaceous. Accordingly, we suggest an Early Cretaceous, Aptian depositional age for this sample. The zircons were derived from a magmatic arc that had been almost continuously active between 172 and $122 \mathrm{Ma}$, with no other input.

Detrital zircon barcodes of the Canyon Creek and Chilligan River samples are remarkably similar to each other. They also resemble a detrital zircon barcode from rocks assigned to the Kahiltna assemblage in the Clearwater Mountains, about 300 $\mathrm{km}$ to the northeast in Healy quadrangle, east-central Alaska Range (B. Hampton, written commun., 2008) (locality 5 in fig. 1B). The probability curve of the Clearwater Mountains sample has a single peak at $156 \mathrm{Ma}$; zircons range from 176 to $139 \mathrm{Ma}$, and Paleozoic and Precambrian zircons are entirely lacking (B. Hampton, written commun., 2008). Possible zircon sources of the Clearwater Mountains sample are the Talkeetna arc (201$153 \mathrm{Ma})$ or the more distant Chitina arc (170-135 Ma) - both of the Wrangellia composite terrane (Hampton and others, 2007). Another good match is shown by a detrital zircon barcode from the restricted Gemuk Group (Miller and others, 2007b) in the Taylor Mountains quadrangle of southwest Alaska (locality 7 in fig. 1B). The probability curve of the Gemuk Group sample has closely spaced peaks at $188,177,167,153$, and $140 \mathrm{Ma}$; zircons range from 292 to $130 \mathrm{Ma}$, Paleozoic zircons are few (only 3 of 56 grains), and Precambrian zircons are absent.

\section{Hornfels Metasandstone of the Max Lake Area- Hauterivian}

The second-oldest detrital zircon sample (05ADw303c) is from a small outcrop area of hornfels in the watershed of the unnamed creek draining Max Lake in Tyonek B-8 quadrangle (fig. 2). These rocks were assigned to Unit Mzu by Reed and Elliott (1970), and to Unit JPzk in the compilation by Wilson and others (1998). In light of the detrital zircon ages reported herein, Wilson et al. (2009) assigned these rocks to their Unit
Kes. The sample is from an outcrop of fine-grained turbidites that have been contact metamorphosed to incipient biotite grade. At the sample site, the beds are upright and dip $82^{\circ}$ to the northwest.

Detrital zircons were analyzed by Apatite to Zircon, Inc., at Washington State University. The detrital zircons range in age from 1985 to $132 \mathrm{Ma}$. Of 100 grains, 3 are Paleoproterozoic, 1 is Mesoproterozoic, 1 is Neoproterozoic, 78 are Jurassic, and 14 are Early Cretaceous. The probability density curve (figs. 3G-H) shows Jurassic peaks at 181 and $149 \mathrm{Ma}$. The depositional age is perhaps a bit younger than the 149-Ma peak, given that 23 grains are younger than this age. The three youngest grains, dated $134 \pm 10 \mathrm{Ma}, 134 \pm 4$, and $132 \pm 7$, are Early Cretaceous. Accordingly, we suggest an Early Cretaceous, Hauterivian depositional age for this sample.

\section{Hornfels Metasandstone of the Crystal Creek Area-Aptian}

Sample 05ADw305a is from an outcrop area of hornfels in the drainage of the Skwenta River, nearly opposite the mouth of Crystal Creek, Tyonek C-8 quadrangle (fig. 2). These rocks were assigned to Unit Km by Reed and Elliott (1970), and to Unit KJf in the compilation by Wilson and others (1998). In light of the detrital zircon ages reported herein, Wilson et al. (2009) assigned these rocks to their Unit Kes. At the sample site, the beds dip $81^{\circ} \mathrm{SW}$ and the younging direction is unknown. The detrital zircon sample is a coarse, poorly sorted sandstone containing angular clasts of quartz, plagioclase, potassium feldspar (minor), chert, and phyllite.

Detrital zircons were analyzed by Apatite to Zircon, Inc., at Washington State University. The detrital zircons range in age from to 2818 to $122 \mathrm{Ma}$. Of 100 grains, 3 are Archean, 8 are Paleoproterozoic, 4 are Mesoproterozoic, 5 are Neoproterozoic, 3 are Triassic, 51 are Jurassic, and 26 are Early Cretaceous. The probability density curve (figs. 3C, D) shows a major midCretaceous peak at $141 \mathrm{Ma}$, a somewhat lesser Middle Jurassic peak at $168 \mathrm{Ma}$, and a minor early Neoproterozoic peak at 944 Ma. The depositional age is perhaps a bit younger than the 141-Ma peak, because 17 grains are younger. The three youngest grains are $129 \pm 3,123 \pm 3$, and $121 \pm 7 \mathrm{Ma}$. Accordingly, we suggest an Early Cretaceous, Aptian depositional age. As for the other samples, we reason that this is probably close to the age of the youngest zircons.

The detrital zircon barcodes of the samples from the Chilligan headwaters and Crystal Creek are similar to each other, being dominated by Jurassic to Early Cretaceous zircons but containing a few Precambrian grains. They differ in the latter respect from the Canyon Creek and Chilligan River samples. None of the four Lower Cretaceous samples from Tyonek quadrangle have detrital zircon barcodes that closely match barcodes from the Kahiltna assemblage to the northeast. Kalbas and others (2007) reported detrital zircon ages from a single sample from eastern McGrath quadrangle (locality 6 in 
fig. 1B) that has grains as young as 109 and $106 \mathrm{Ma}$, a major peak at ca. $200 \mathrm{Ma}$, a minor peak at ca. $350 \mathrm{Ma}$, and no grains at all in the 155-140 Ma interval (in contrast, this is the dominant peak in all four Lower Cretaceous samples from Tyonek quadrangle). Hampton and others (2007) reported detrital zircon ages from four samples in southwestern Healy quadrangle (locality 3 in fig. 1B) that all feature major peaks at ca. 200 $\mathrm{Ma}$, a scattering of Devonian and Mississippian zircons, and a notable paucity of grains in the 155-140 Ma interval.

\section{Hornfels Metasandstone of the Emerald Creek Area-Coniacian}

Sample 05PH105a is from the Skwentna River drainage, a few kilometers south of Emerald Creek, in northern Tyonek C-8 quadrangle (fig. 2). These rocks were assigned to Unit KM? by Reed and Elliott (1970; their query), and to Unit JPzk in the compilation by Wilson and others (1998). In light of the detrital zircon ages reported herein, Wilson et al. (2009) assigned these rocks to their Unit KJs. The sample is from an outcrop of weakly contact-metamorphosed coarse graywacke and slate. Beds dip $59^{\circ} \mathrm{N}$ and the younging direction is unknown. In thin section, the rock is a very coarse, poorly sorted sandstone containing euhedral crystals of plagioclase and pyroxene, as well as volcanic and siltstone rock fragments.

Detrital zircons were analyzed by Apatite to Zircon, Inc., at Washington State University. The detrital zircons range in age from 1837 to $84 \mathrm{Ma}$. Of 100 grains, 5 are Paleoproterozoic, 3 are Neoproterozoic, 2 are Cambrian, 2 are Ordovician, 1 is Silurian, 1 is Triassic, 10 are Jurassic, 36 are Early Cretaceous, and 37 are Late Cretaceous. The probability density curve (fig. 3I-J) shows a major mid-Cretaceous peak at 100 $\mathrm{Ma}$ and a lesser Late Jurassic peak at $153 \mathrm{Ma}$. The depositional age must be younger than the 100-Ma peak, because 42 grains are younger than this. The three youngest grains, dated $88 \pm 3,87 \pm 4$, and $86 \pm 4 \mathrm{Ma}$, are Late Cretaceous. Accordingly, we suggest a Late Cretaceous, Coniacian depositional age for this sample.

\section{Hornfels Metasandstone of the Peak 6105 Area-Paleogene}

Sample 05PH104b is from an outcrop belt of contactmetamorphosed volcanic and sedimentary rocks in the Skwentna River drainage in southern Tyonek C8 quadrangle (fig. 2). These rocks were assigned to Unit Mzu by Reed and Elliott (1970) and to Unit JPzk by Wilson and others (1998). In light of the detrital zircon ages reported herein, Wilson et al. (2009) assigned these rocks to their Unit Tves. The sample is from an outcrop of volcanogenic sandstone and conglomerate (fig. $4 \mathrm{G})$. At the sample site, beds are overturned and dip $83^{\circ} \mathrm{NE}$. Shortening must have postdated $55 \mathrm{Ma}$. The detrital zircon sample is a hornfels fine-grained sandstone preserving only some of the original sedimentary grains.

Detrital zircons were analyzed by Apatite to Zircon, Inc., at Washington State University. The detrital zircons range in age from 1982 to $55 \mathrm{Ma}$. Of 100 grains, 3 are Paleoproterozoic, 2 are Mesoproterozoic, 1 is Neoproterozoic, 2 are Cambrian, 3 are Early Cretaceous, 16 are Late Cretaceous, 67 are Paleocene, 2 are Eocene, and 4 did not pass the filters. The probability density curve shows a single peak at ca. 65 Ma (fig. 3Q, R). The maximum possible depositional age is certainly younger than this, because 66 grains are younger than the peak. The three youngest grains, dated $56 \pm 1,56 \pm$ $2,55 \pm 1 \mathrm{Ma}$, span the Paleocene boundary at $55.8 \mathrm{Ma}$ (time scale of Gradstein and Ogg, 2004). Accordingly, we suggest an earliest Eocene or latest Paleocene depositional age for this sample, following the same logic as for other samples. Most of the detrital zircons were derived from a magmatic arc that was active between approximately 73 and $55 \mathrm{Ma}$; many possible sources exist nearby in the plutons and volcanic fields of this age range in the western Alaska Range. The sparse older grains are most easily explained as third-cycle (or higher) detrital zircons derived locally from erosion of older rocks such as the Lower Cretaceous ("Kahiltna") turbidites.

\section{Tectonic Implications}

Implications for regional geology, stratigraphy, and correlation were discussed above in the individual sections on the individual samples. Table 1 summarizes the inferred depositional ages. Here we will explore the implications for the tectonic history of south-central Alaska.

\section{Chugach terrane}

The Chugach terrane has long been regarded as an accretionary wedge that was built along the seaward margin of the Wrangellia composite terrane, which was the site of intermittent arc magmatism during the Mesozoic (Plafker and others, 1994). The age difference between sandstones of the McHugh Complex (93-91 Ma or younger) and Valdez Group (78-77 Ma or younger), while narrower than formerly suspected, is still consistent with the long-held belief that the McHugh was accreted before the Valdez. Parts of the McHugh Complex must have been accreted still earlier than the conglomerate of Beluga Point, because the McHugh Complex in northern Anchorage quadrangle was intruded by syntectonic plutons at ca. 135-125 Ma (Pavlis and others, 1988).

\section{Talkeetna Mountains}

The schist of Hatcher Pass crops out along the northern margin of the Cook Inlet-Matanuska forearc basin. It pres- 
ents a problem, because its state of penetrative deformation and metamorphism stands in stark contrast to the nearby, apparently coeval, unmetamorphosed Matanuska Formation (Trop, 2008). This marine succession was deposited during the Late Cretaceous in the Matanuska basin. A recent detrital zircon study of the Matanuska Formation (from locality 12 in fig. 1B) showed that the 10 youngest grains range from 76 to $72 \mathrm{Ma}$ with a mean of $74 \pm 1 \mathrm{Ma}$ (Trop, 2008), making it essentially the same age as the protolith of the schist of Hatcher Pass. It seems unlikely, however, that the Matanuska Formation could represent the protolith. For one thing, the Matanuska Formation entirely lacks Precambrian grains, which make up some 20 percent of the Hatcher Pass detrital zircon sample. An additional problem is the lack of any plausible mechanism for subjecting forearc basin deposits to the intense metamorphism and bedding transposition that characterizes the schist of Hatcher Pass. As noted earlier, the detrital zircon barcode of the schist of Hatcher Pass is reminiscent of barcodes from the Kuskokwim Group in Taylor Mountains quadrangle (locality 8 in fig. 1B), the Minto unit (locality 1 in fig. 1B), and the Caribou Pass Formation (locality 4 in fig. 1B). Of these, only the Caribou Pass Formation is in the right part of the world to conceivably be related to the schist of Hatcher Pass. This possibility, however, has the same problem as the Matanuska Formation: how to explain the intense deformation and metamorphism in a supra-subduction setting.

By elimination, we suggest a different scenario: that the protolith sediments of the schist of Hatcher Pass were deposited on a subducting plate in the paleo-North Pacific (presumably the Resurrection Plate; Haeussler and others, 2003). This depositional setting is also inferred for the Valdez Group (Nilsen and Zuffa, 1982). Immediately after deposition, the sedimentary package entered the subduction zone, and much of it was soon offscraped and (or) underplated, to be subsequently exposed in the Chugach terrane as the Valdez Group. The strata that were to become the schist of Hatcher Pass were carried much farther down the subduction zone. This package of rocks was eventually exhumed through transtension along the Castle Mountain Fault in the late Paleocene, during deposition of the Arkose Ridge Formation (Bradley and others, 2003). A similar chain of events has been recognized in the Mojave Desert, where the Orocopia Schist is believed to have been subducted beneath the Pacific margin and later exhumed, far inland, during Basin and Range extension (Jacobson and others, 2007). In our model, the schist of Hatcher Pass is relatively far traveled, having been deposited on a different plate a few hundred kilometers seaward of its final position. This model also accounts for the lozenges of ultramafic rock (Winkler, 1992) within the outcrop belt of the schist as fault slices of subducted oceanic lithosphere. A weakness of the Hatcher Pass schist-Valdez Group correlation is that Precambrian detrital zircons are fairly abundant in the former, and relatively scarce in the latter. More data are needed from both units.

\section{Western Alaska Range}

The Alaska Range samples were deposited over an interval of about 80 m.y. and record several stages in the regional tectonic evolution. On the basis of both age and position, the four Lower Cretaceous samples would appear to be part of the fill to the Kahiltna basin system, which has been most thoroughly studied to the north and northeast in the central Alaska Range (Kalbas and others, 2007; Hampton and others, 2007; Trop and Ridgway, 2007). The Kahiltna basin system lay between the Wrangellia composite terrane and previously tectonized terranes along the North American margin (the largest being the Yukon-Tanana and Farewell terranes) (fig. 1B). Along the basin's southeastern margin in the Healy quadrangle (localities 2 and 3 in fig. 1B), the Kahiltna was derived from the southeast, from Mesozoic arc sources in the Wrangellia composite terrane (Hampton and others, 2007) (fig. 1B). Near the opposite basin margin farther to the northwest (locality 6 in fig. 1B), the Kahiltna has been interpreted to represent the syncollisional fill of a narrowing ocean that evolved into a foredeep (Kalbas and others, 2007). In this part of the basin, the Kahiltna received clastic input not only from the Mesozoic arc sources of the Wrangellia composite terrane, but also from inboard orogenic highlands underlain by older rocks. The detrital zircon samples from the Tyonek quandrangle are broadly consistent with this framework, with the unimodal Canyon Creek and Chilligan samples having been derived from a southeasterly arc source and the Max Lake and Crystal Creek samples also including some detritus from inboard sources, perhaps the Farewell terrane (fig. 1B).

The Upper Cretaceous and Paleogene samples provide additional evidence for a polyphase depositional history in the northwestern Tyonek quadrangle, which we now know contains deformed strata as young as ca. $55 \mathrm{Ma}$. Both the Upper Cretaceous and the Paleogene strata were deposited in a retroarc setting above the ancestor to the modern subduction zone. It is not known whether the Upper Cretaceous strata of northwestern Tyonek quadrangle were deposited in the same basin as the Kuskokwim Group of southwest Alaska or in a different basin at the same time. The Paleogene strata of the Peak 6105 area appear to be broadly correlative with the upper part of the Cantwell Group of the central Alaska Range (locality 2 in fig. 1B) (Ridgway and others, 1997), though likely deposited in a different basin.

\section{Implications for ca. 90-Ma Metallogeny}

The Turonian (ca. $90 \mathrm{Ma}$ ) is an important but poorly documented time in the metallogenic history of south-central Alaska, being the age of the supergiant Pebble Copper porphyry system near Lake Iliamna (Bouley and others, 1995; 
Schrader and others, 2001) (locality 11 in fig. 1B). Arcrelated plutons of equivalent age would be prospective for porphyry-type mineralization, and such plutons are known far to the northeast of the Pebble prospect in the central Alaska Range, across an apparent 500-km magmatic gap. The question for exploration and mineral assessment in the intervening area (western Alaska Range and Talkeetna Mountains) is whether or not ca. 90-Ma plutons exist, or at least once existed.

Six detrital zircon samples in the present study are young enough that they could conceivably include ca. $90-\mathrm{Ma}$ grains. Five of the six samples do, in fact, contain zircons between 93 and $87 \mathrm{Ma}$ - the McHugh Complex, Valdez Group, schist of Hatcher Pass, Arkose Ridge Formation, and hornfels of the Emerald Lake area (table 2). For all of these but the Arkose Ridge, a specific sources cannot yet be identified, so little can be said about where these ca. 90-Ma zircons actually came from. The Arkose Ridge Formation, however, was clearly derived the Talkeetna Mountains, and its abundant ca. 90-Ma detrital zircons point to the presence of ca. 90-Ma plutons in that area that have not been mapped, have not been dated (see footnote 10, added in proof), have been buried, or have been eroded away.

\section{Acknowledgments}

We thank Joe Wooden and Frank Mazdab for help in the USGS-Stanford SHRIMP lab. Reviews by Heather Bleick and Ken Ridgway substantially improved the manuscript. Ric Wilson and Chad Hults provided the draft map that forms the base of Figure 2. Heather Bleick and Peter Cervelli helped with data analysis and presentation. Imagining that one day it would prove datable, Tim Kusky had the foresight to collect the small granite clast from the Valdez Group. We also thank Marti Miller, Brian Hampton, and Jay Kalbas, whose detrital zircon studies on other Cretaceous strata in the region serve as an important basis for comparison.

\section{References Cited}

Bickford, M.E., Cullers, R.L., Shuster, R.D., Premo, W.R., and Van Schmus, W.R., 1989, U-Pb zircon geochronology of Proterozoic and Cambrian plutons in the Wet Mountains and southern Front Range, Colorado: Geological Society of America Special Paper 235, p. 49-64.

Black, L.P., Kamo, S., Allen, C., Davis, D., Aleinikoff, J.A., Valley, J., Mundil, R., Campbell, I.H., Korsch, R., Williams, I.S. and Foudoulis, C., 2004, Improved ${ }^{206} \mathrm{~Pb} / 238 \mathrm{U}$ microprobe geochronology by the monitoring of a traceelement related matrix effect; SHRIMP, ID-TIMS, ELAICP-MS and oxygen isotope documentation for a series of zircon standards: Chemical Geology, v. 205, p. 115-140.
Bouley, B.A., St. George, P., and Wetherbee, P.K., 1995, Geology and discovery at Pebble Copper, a copper-gold porphyry system in southwest Alaska: Canadian Institute of Mining, Metallurgy, and Petroleum, Special Volume 46, p. 422-435.

Box, S.E., and Elder, W.P., 1992, Depositional and biostratigraphic framework of the Upper Cretaceous Kuskokwim Group, southwestern Alaska: U.S. Geological Survey Bulletin 1999, p. 8-16.

Bradley, D.C., and Kusky, T.M., 1992, Deformation history of the McHugh Complex, Seldovia quadrangle, south-central Alaska: U.S. Geological Survey Bulletin 1999, p. 17-32.

Bradley, D., and Miller, M., 2006, Field guide to south-central Alaska's accretionary complex, Anchorage to Seward: Anchorage, Alaska, Alaska Geological Society, 32 p.

Bradley, D.C., Kusky, T.M., Haeussler, P., Karl, S.M., and Donley, D.T., 1999, Geologic map of the Seldovia quadrangle: U.S. Geological Survey Open File Report 99-18, scale 1:250,000. [Also available online: http://pubs.usgs.gov/of/1999/of99-018/]

Bradley, D., Kusky, T., Haeussler, P., Goldfarb, R., Miller, M., Dumoulin, J., Nelson, S., and Karl, S., 2003, Geologic signature of early Tertiary ridge subduction in Alaska, in Sisson, V.B., Roeske, S.M., and Pavlis, T.L., eds., Geology of a transpressional orogen developed during ridge-trench interaction along the north Pacific margin: Geological Society of America Special Paper 371, p. 19-49.

Bradley, D.C., McClelland, W., Wooden, J., Till, A.B., Roeske, S., Miller, M.L., Karl, S., and Abbott, G., 2007, Detrital zircon geochronology of some Neoproterozoic to Triassic rocks in interior Alaska, in Ridgway, K.D., Trop, J.M., Glen, J.M.G., and O'Neill, J.M., eds., Tectonic growth of a collisional continental margin, crustal evolution of southern Alaska: Geological Society of America Special Paper 431, p. 155-180.

Capps, S.R., 1915, The Willow Creek district, Alaska: U.S. Geological Survey Bulletin 607, 86 p.

Clark, S.H.B., 1973, The McHugh Complex of south-central Alaska: U.S. Geological Survey Bulletin 1372-D, 11 p.

Clark, S.H.B., 1981, Guide to bedrock geology along the Seward Highway north of Turnagain Arm: Anchorage, Alaska Geological Society, Publication no. 1, 36 p.

Clement, S.W.J., and Compston, W., 1994, Ion probe parameters for very high resolution without loss of sensitivity: U.S. Geological Survey Circular 1107, 62 p.

Csejtey, Bela, Jr., Nelson, W.H., Jones, D.L., Silberling, N.J., Dean, R.M., Morris, M.S., Lanphere, M.A., Smith, J.G., and Silberman, M.L., 1978, Reconnaissance geologic map and geochronology, Talkeetna Mountains Quadrangle, northern part of Anchorage Quadrangle, and southwest corner of Healy Quadrangle, Alaska: U.S. Geological Survey OpenFile Report 78-558-A, 60 p., 1 sheet, scale 1:250,000.

Dumoulin, J.A., 1987, Sandstone composition of the Valdez and Orca Groups, Prince William Sound, Alaska: U.S. Geological Survey Bulletin 1774, 37 p. 
Fischietto, N.E., Rothfuss, J.L., Flanagan, D., and Cole, R.B., 2006, Provenance of a deformed conglomerate in the Mesozoic McHugh Complex mélange, Anchorage quadrangle, Alaska: Geological Society of America Abstracts with Programs, v. 38, no. 7, p. 143.

Gradstein, F.M., and Ogg, J.G., 2004, A geologic time scale 2004: Cambridge, Cambridge University Press, 598 p., 1 plate.

Haeussler, P.J., Bradley, D.C., Wells, R.E., and Miller, M.L., 2003, Life and death of the Resurrection Plate; evidence for an additional plate in the northeastern Pacific in PaleoceneEocene time: Geological Society of America Bulletin, v. 115, p. 867-880.

Haeussler, P.J., Gehrels, G.E., and Karl, S.M., 2006, Constraints on the age and provenance of the Chugach accretionary complex from detrital zircons in the Sitka Graywacke near Sitka, Alaska: U. S. Geological Survey Professional Paper 1709-F, 24 p.

Hampton, B.A., Ridgway, K.D., O’Neill, J.M., Gehrels, G.E., Schmidt, J., and Blodgett, R.B., 2007, Pre-, syn-, and postcollisional stratigraphic framework and provenance of Upper Triassic-Upper Cretaceous strata in the northwestern Talketna Mountains, Alaska, in Ridgway, K.D., Trop, J.M., Glen, J.M.G., and O’Neill, J.M., eds., Tectonic growth of a collisional continental margin, crustal evolution of southern Alaska: Geological Society of America Special Paper 431, p. 401-438.

Hampton, B., and Sunderlin, D., 2008, Provenance and paleoflora of the Cretaceous Caribou Pass Formation, southcentral Alaska: Development of a collisional foreland in the final stages of island arc accretion: Geological Society of America Abstracts with Programs, v. 40, no. 6, p. 156.

Harlan, S.S., Snee, L.W., Vielreicher, R.M., Goldfarb, R.G., Mortensen, J.K., and Bradley, D.C., 2003, Age and cooling history of gold deposits and host rocks in the Willow Creek mining district, Talkeetna Mountains, south-central Alaska: Geological Society of America Abstracts with Programs, v. 35 , no. 6, p. 235.

Ireland, T.R, and Williams, I.S, 2003, Considerations in zircon geochronology by SIMS: Reviews in Mineralogy and Geochemistry, v. 53, p. 215-241.

Jacobson, C.E., Grove, M., Vucic, A., Pedrick, J.N., and Ebert, K.A., 2007, Exhumation of the Orocopia Schist and associated rocks of southeastern California; relative roles of erosion, synsubduction tectonic denudation, and middle Cenozoic extension: Geological Society of America Special Paper 419, p. 1-37.

Kalbas, J.L., Ridgway, K.D., and Gehrels, G.E., 2007, Stratigraphy, depositional systems, and provenance of the Lower Cretaceous Kahiltna assemblage, western Alaska Range; basin development in response to oblique collision, in Ridgway, K.D., Trop, J.M., Glen, J.M.G., and O’Neill, J.M., eds., Tectonic growth of a collisional continental margin, crustal evolution of southern Alaska: Geological Society of America Special Paper 431, p. 307-343.
Kusky, T.M., Bradley, D.C., Haeussler, Peter, and Karl, Susan, 1997, Controls on accretion of flysch and mélange belts at convergent margins, evidence from the Chugach Bay thrust and Iceworm mélange, Chugach Terrane, Alaska: Tectonics, v. 16 , p. $855-878$.

Kusky, T.M., Glass, A., and Tucker, R., 2007, Structure, Cr-chemistry, and age of the Border Ranges UltramaficMafic Complex, a suprasubduction zone ophiolite complex, in Ridgway, K.D., Trop, J.M., Glen, J.M.G., and O’Neill, J.M., eds., Tectonic growth of a collisional continental margin, crustal evolution of southern Alaska: Geological Society of America Special Paper 431, p. 207-226.

Ludwig, K.R., 2001, Squid 1.00, a users manual: Berkeley Geochronology Center Special Publication No. 2, 17 pp.

Ludwig, K.R., 2003, Isoplot 3.00, a geochronological toolkit for Microsoft Excel: Berkeley Geochronology Center, Special Publication No. 4a, Berkeley, California.

Miller, M.L., Bradley, D.C., Kalbas, J.L., Friedman, R., and O’Sullivan, P.B., 2007a, Detrital zircon geochronology of the Upper Cretaceous Kuskokwim Group, southwestern Alaska: Geological Society of America Abstracts with Programs, v. 39, no. 6, p. 489.

Miller, M.L., Bradley, D.C., Bundtzen, T.K., Pessagno, E.A., Jr., Blodgett, R.B., Tucker, R., and Wooden, J., 2007b, The restricted Gemuk Group - a Triassic to Early Cretaceous succession in southwest Alaska, in Ridgway, K.D., Trop, J.M., Glen, J.M.G., and O’Neill, J.M., eds., Tectonic growth of a collisional continental margin, crustal evolution of southern Alaska: Geological Society of America Special Paper 431, p. 273-305.

Nelson, S.W., Blome, C.D., Harris, A.G., Reed, K.M., and Wilson, F.H., 1986, Late Paleozoic and Early Jurassic fossil ages from the McHugh Complex: U.S. Geological Survey Circular 978, p. 60-64.

Nilsen, T.H., and Zuffa, G.G., 1982, The Chugach terrane, a Cretaceous trench-fill deposit, southern Alaska: Geological Society of London Special Publication 10, p. 213-227.

Paces, J.B., and Miller, J.D., 1993, U-Pb ages of the Duluth Complex and related mafic intrusions, northeastern Minnesota; geochronologic insights into physical, paleomagnetic and tectonomagmatic processes associated with the $1.1 \mathrm{Ga}$ mid-continent rift system: Journal Geophysical Research, v. 98, p. 13997-14013.

Pavlis, T.L., Monteverde, D.H., Bowman, J.R., Rubenstone, J.L., and Reason, M.D., 1988, Early Cretaceous near-trench plutonism in southern Alaska: A tonalite-trondhjemite intrusive complex injected during ductile thrusting along the Border Ranges fault system: Tectonics, v. 7, p. 1179-1199.

Plafker, G., Moore, J.C., and Winkler, G.R., 1994, Geology of the southern Alaska margin, in Plafker, G., and Berg, H.C., eds., The geology of Alaska: Geological Society of America, Decade of North American Geology (DNAG) Series, v. G-1, p. 389-449.

Reed, B.L., and Elliott, R.L., 1970, Reconnaissance geologic map, analyses of bedrock and stream sediment samples, and 
aeromagnetic map of parts of the southern Alaska Range: U.S. Geological Survey Open-File Report 70-271, 145 p., scale $1: 250,000$.

Reed, B.L., and Nelson, S.W., 1980, Geologic map of the Talkeetna Quadrangle, Alaska: U.S. Geological Survey Miscellaneous Investigations 1174, 15 p., 1 sheet, scale $1: 250,000$.

Rioux, M., Hacker, B., Mattinson, J., Kelemen, P., Blusztajn, J., and Gehrels, G., 2007, Magmatic development of an intra-oceanic arc; high-precision $\mathrm{U}-\mathrm{Pb}$ zircon and wholerock isotopic analyses from the accreted Talkeetna arc, south-central Alaska: Geological Society of America Bulletin, v. 119, p. 1168-1184. doi: 10.1130/B25964.1.

Schrader, C.M., Crowe, D., Turner, K., and Stein, H.J., $2001,{ }^{40} \mathrm{Ar} /{ }^{39} \mathrm{Ar}$ and geochronology of the Pebble Copper $\mathrm{Cu}-\mathrm{Au}-\mathrm{Mo}$ porphyry deposit, southwest Alaska: Geological Society of America Abstracts with Programs, v.33, no. 6, p. 418.

Solie, D.N., Gilbert, W.G., Harris, E.E., Kline, J.T., Liss, M.S., and Robinson, M.S., 1991, Preliminary geologic map of Tyonek D-6 and eastern Tyonek D-7 quadrangles, Alaska: Alaska Division of Geological and Geophysical Surveys, Public Data File 91-10, 16 p., 1 sheet, scale $1: 40,000$.

Stacey, J.S., and Kramers, J.D., 1975, Approximation of terrestrial lead isotope evolution by a two-stage model: Earth and Planetary Science Letters, v. 26, p. 207-221.

Stevens, C.H., Davydov, V.I., and Bradley, D.C., 1997, Permian Tethyan fusilinids from the Kenai Peninsula, Alaska: Journal of Paleontology, v. 71, p. 985-994.

Trop, J.M., 2008, Latest Cretaceous forearc basin development along an accretionary convergent margin; south-central Alaska: Geological Society of America Bulletin, v. 120, p. 207-224.

Trop, J.M, and Ridgway, K.D., 2002, Sedimentology and provenance of the Paleocene-Eocene Arkose Ridge Formation, Cook Inlet-Matanuska Valley forearc basin, southern Alaska: Alaska Division of Geological and Geophysical Surveys Professional Report 119, p. 129144.

Trop, J.M., and Ridgway, K.D., 2007, Mesozoic and Cenozoic tectonic growth of southern Alaska; a sedimentary basin perspective, in Ridgway, K.D., Trop, J.M., Glen, J.M.G., and O'Neill, J.M., eds., Tectonic growth of a collisional continental margin, crustal evolution of southern Alaska:
Geological Society of America Special Paper 431, p. 55-94. doi: 10.1130/2007.2431(04).

Tysdal, R.G., and Case, J.E., 1977, The McHugh Complex in the Seward Quadrangle, south-central Alaska: U. S. Geological Survey Circular 751-B, p. B48-B49.

Tysdal, R.G., and Case, J.E., 1979, Geologic map of the Seward and Blying Sound quadrangles, Alaska: U.S. Geological Survey Miscellaneous Investigations 1150, 12 p., scale 1:250,000.

Tysdal, R.G., and Plafker, G., 1978, Age and continuity of the Valdez Group, southern Alaska: U.S. Geological Survey Bulletin 1457-A, p. A120-A124.

Van Wyck, N., and Norman, M., 2005, Detrital zircon dates as a constraint on the age of metasedimentary rocks in the Hatchers Pass area, south-central Alaska: Geological Society of America Abstracts with Programs, v. 37, no. 7, p. 82.

Wallace, W.K., Hanks, C.L., and Rogers, J.F., 1989, The southern Kahiltna terrane; implications for the tectonic evolution of southwestern Alaska: Geological Society of America Bulletin, v. 101, p. 1389-1407.

Weber, F.R., Wheeler, K.L., Rinehart, C.D., Chapman, R.M., and Blodgett, R.B., 1992, Geologic map of the Livengood quadrangle, Alaska: U.S. Geological Survey Open-File Report 92-562, 20 p., scale 1:250,000.

Williams, I.S., 1997, U-Th-Pb geochronology by ion microprobe: Reviews in Economic Geology, v. 7, p. 1-35.

Wilson, F.H., Dover, J.H., Bradley, D.C., Weber, F.R., Bundtzen, T.K., and Haeussler, P.J., 1998, Geologic map of central (interior) Alaska: U.S. Geological Survey Open-File Report 98-133, 64 p., 3 plates, scale 1:500,000.

Wilson, F.W., Hults, C.P., Schmoll, H.R., Haeussler, P.J., Schmidt, J.M., Yehle, L.A., and Labay, K.A., 2009, Preliminary geologic map of the Cook Inlet region, Alaska: U.S. Geological Survey Open-File Report 2009-1108, 99 p., 2 plates, scale 1:250,000.

Winkler, G.R., 1992, Geologic map and summary geochronology of the Anchorage $1^{\circ} \times 3^{\circ}$ quadrangle, southern Alaska: U.S. Geological Survey Miscellaneous Investigations 2283, 1 sheet, scale 1:250,000.

Winkler, G.R., Silberman, M.L., Grantz, Arthur, Miller, R.L., and MacKevett, E.M., Jr., 1981, Geologic map and summary geochronology of the Valdez quadrangle, southern Alaska: U.S. Geological Survey Open-File Report 80-892A, 2 sheets, scale 1:250,000. 
Table 2. U-Pb analytical data for detrital and igneous zircons, identified by sample number and lab.

[Analyses that do not pass discordance and error/age filters are shown in strike-through format. Because each lab reports its results in slightly different format, some columns are empty for some samples.]

\begin{tabular}{|c|c|c|c|c|c|c|c|c|c|c|c|c|c|}
\hline \multicolumn{14}{|c|}{ 04ATi109, detrital zircons, $n=55$, SHRIMP-RG } \\
\hline Spot name & $207 r / 235$ & $\begin{array}{c}1 \sigma \\
\text { error } \\
(\%)\end{array}$ & $206 r / 238$ & $\begin{array}{l}1 \sigma \\
\text { error } \\
(\%)\end{array}$ & $\begin{array}{l}\text { Error } \\
\text { cor- } \\
\text { relation }\end{array}$ & $\begin{array}{c}207 \text { corr } \\
206 / 238 \\
\text { age } \\
(\mathrm{Ma})\end{array}$ & $\begin{array}{l}1 \sigma \\
\text { error } \\
\text { (m.y.) }\end{array}$ & $\begin{array}{c}204 \text { corr } \\
207 / 206 \\
\text { Age } \\
\text { (Ma) }\end{array}$ & $\begin{array}{c}1 \sigma \\
\text { error } \\
\text { (m.y.) }\end{array}$ & $\begin{array}{l}\text { Best } \\
\text { age } \\
\text { (Ma) }\end{array}$ & $\begin{array}{c}1 \sigma \\
\text { error } \\
\text { (m.y.) }\end{array}$ & Error/age & $\begin{array}{c}\text { Dis- } \\
\text { cordance } \\
(\%)\end{array}$ \\
\hline 04ATi109-47.1 & 0.08 & 6.7 & .0117 & 1.8 & .262 & 75.1 & 1.3 & 165.9 & 150.7 & 75.1 & 1.3 & 0.018 & 120 \\
\hline 04ATi109-19.1 & 0.08 & 5.3 & .0118 & 1.4 & .259 & 75.4 & 1.1 & 47.7 & 123.2 & 75.4 & 1.1 & 0.014 & -37 \\
\hline 04ATi109-16.1 & 0.07 & 11.6 & .0119 & 2.9 & .251 & 76.3 & 2.3 & -58.5 & 274.0 & 76.3 & 2.3 & 0.030 & -177 \\
\hline 04ATi109-25.1 & 0.10 & 5.7 & .0132 & 1.5 & .260 & 83.7 & 1.3 & 333.8 & 123.7 & 83.7 & 1.3 & 0.015 & 296 \\
\hline 04ATi109-9.1 & 0.09 & 9.9 & .0131 & 2.6 & .261 & 84.3 & 2.2 & 47.2 & 229.2 & 84.3 & 2.2 & 0.026 & -44 \\
\hline 04ATi109-31.1 & 0.09 & 3.9 & .0134 & 1.0 & .265 & 85.8 & 0.9 & 154.5 & 87.0 & 85.8 & 0.9 & 0.010 & 80 \\
\hline 04ATi109-1 & 0.10 & 4.3 & .0135 & 1.2 & .269 & 86.3 & 1.0 & 242.0 & 95.7 & 86.3 & 1.0 & 0.012 & 179 \\
\hline 04АТі109-40.1 & 0.09 & 6.4 & .0137 & 1.6 & .257 & 87.5 & 1.5 & 56.6 & 146.8 & 87.5 & 1.5 & 0.017 & -35 \\
\hline 04АТі109-36.1 & 0.08 & 11.2 & .0137 & 1.5 & .135 & 88.7 & 1.3 & -275.7 & 282.6 & 88.7 & 1.3 & 0.015 & -413 \\
\hline 04АТі109-32.1 & 0.10 & 3.9 & .0159 & 1.1 & .267 & 101.9 & 1.1 & 85.8 & 90.2 & 101.9 & 1.1 & 0.011 & -16 \\
\hline 04АТі109-48.1 & 0.11 & 5.1 & .0160 & 1.4 & .267 & 101.9 & 1.4 & 170.4 & 115.3 & 101.9 & 1.4 & 0.014 & 67 \\
\hline 04ATi109-23.1 & 0.10 & 5.1 & .0159 & 1.1 & .218 & 102.0 & 1.2 & 64.2 & 119.1 & 102.0 & 1.2 & 0.011 & -37 \\
\hline 04ATi109-34.1 & 0.11 & 2.7 & .0162 & 0.7 & .267 & 103.9 & 0.8 & 97.4 & 60.7 & 103.9 & 0.8 & 0.007 & -6 \\
\hline 04АТі109-59.1 & 0.11 & 3.5 & .0167 & 0.9 & .251 & 106.6 & 1.0 & 175.5 & 79.2 & 106.6 & 1.0 & 0.009 & 64 \\
\hline 04АТі109-39.1 & 0.13 & 7.8 & .0191 & 2.1 & .273 & 122.0 & 2.6 & 211.9 & 173.9 & 122.0 & 2.6 & 0.022 & 73 \\
\hline 04ATi109-53.1 & 0.14 & 9.4 & .0235 & 1.7 & .185 & 151.0 & 2.6 & -169.8 & 231.2 & 151.0 & 2.6 & 0.017 & -213 \\
\hline 04АТі109-57.1 & 0.16 & 3.4 & .0241 & 0.9 & .276 & 153.6 & 1.5 & 144.4 & 76.4 & 153.6 & 1.5 & 0.009 & -6 \\
\hline 04ATi109-5.1 & 0.18 & 8.4 & .0248 & 1.8 & .211 & 157.6 & 2.8 & 288.9 & 188.5 & 157.6 & 2.8 & 0.018 & 83 \\
\hline 04ATi109-37.1 & 0.17 & 6.0 & .0259 & 1.7 & .279 & 165.2 & 2.8 & 142.9 & 135.4 & 165.2 & 2.8 & 0.017 & -13 \\
\hline 04ATi109-28.1 & 0.18 & 5.4 & .0261 & 1.0 & .188 & 166.5 & 1.7 & 134.9 & 125.4 & 166.5 & 1.7 & 0.010 & -19 \\
\hline 04ATi109-45.1 & 0.20 & 3.9 & .0292 & 0.9 & .221 & 185.9 & 1.6 & 124.3 & 89.2 & 185.9 & 1.6 & 0.009 & -33 \\
\hline 04ATi109-46.1 & 0.20 & 1.7 & .0293 & 0.4 & .224 & 186.4 & 0.7 & 163.6 & 38.5 & 186.4 & 0.7 & 0.004 & -12 \\
\hline 04ATi109-11.1 & 0.19 & 6.0 & .0305 & 1.0 & .170 & 194.5 & 1.9 & -14.7 & 142.4 & 194.5 & 1.9 & 0.010 & -108 \\
\hline 04AТі109-8.1 & 0.40 & 2.0 & .0551 & 0.8 & .386 & 346.2 & 2.7 & 325.5 & 41.8 & 346.2 & 2.7 & 0.008 & -6 \\
\hline 04ATi109-35.1 & 0.41 & 2.5 & .0557 & 0.8 & .322 & 349.5 & 2.8 & 320.9 & 52.9 & 349.5 & 2.8 & 0.008 & -8 \\
\hline 04ATi109-10.1 & 0.61 & 2.7 & .0761 & 1.0 & .359 & 471.4 & 4.5 & 547.1 & 54.3 & 471.4 & 4.5 & 0.010 & 16 \\
\hline 04ATi109-24.1 & 0.88 & 1.9 & .1050 & 0.7 & .400 & 644.2 & 4.8 & 621.2 & 37.0 & 644.2 & 4.8 & 0.007 & -3 \\
\hline 04ATi109-3.1 & 1.76 & 3.3 & .1710 & 1.0 & .301 & 1016.1 & 10.0 & 1053.4 & 63.0 & 1016.1 & 10.0 & 0.010 & 4 \\
\hline 04АТі109-38.1 & 1.83 & 30.2 & .1653 & 2.6 & .086 & 977.0 & 16.2 & 1202.9 & 593.8 & 1202.9 & 593.8 & 0.494 & 22 \\
\hline 04АТі109-12.1 & 1.88 & 9.3 & .1583 & 1.2 & .125 & 930.0 & 8.4 & 1344.6 & 178.4 & 1344.6 & 178.4 & 0.133 & 42 \\
\hline 04ATi109-6.1 & 1.89 & 1.3 & .1408 & 0.4 & .328 & 819.2 & 3.4 & 1575.0 & 22.3 & 1575.0 & 22.3 & 0.014 & 85 \\
\hline 04ATi109-54.1 & 2.65 & 1.0 & 1899 & 0.4 & .435 & 1089.7 & 4.6 & 1648.2 & 16.4 & 1648.2 & 16.4 & 0.010 & 47 \\
\hline 04АТі109-17.1 & 4.99 & 1.9 & .3267 & 0.9 & .506 & 1823.7 & 17.2 & 1811.0 & 29.3 & 1811.0 & 29.3 & 0.016 & -1 \\
\hline 04ATi109-4.1 & 3.97 & 0.9 & .2589 & 0.5 & .567 & 1452.9 & 7.3 & 1821.4 & 13.4 & 1821.4 & 13.4 & 0.007 & 23 \\
\hline 04АТі109-26.1 & 5.29 & 1.6 & .3417 & 1.0 & .641 & 1902.9 & 19.7 & 1835.8 & 22.5 & 1835.8 & 22.5 & 0.012 & -3 \\
\hline 04ATi109-27.1 & 5.28 & 1.2 & .3328 & 0.8 & .652 & 1848.4 & 13.9 & 1880.0 & 15.8 & 1880.0 & 15.8 & 0.008 & 2 \\
\hline 04АТі109-51.1 & 4.13 & 1.1 & .2597 & 0.7 & .604 & 1451.0 & 9.7 & 1884.6 & 16.1 & 1884.6 & 16.1 & 0.009 & 27 \\
\hline 04ATi109-29.1 & 6.18 & 1.0 & .3659 & 0.7 & .663 & 2012.9 & 13.3 & 1991.6 & 13.2 & 1991.6 & 13.2 & 0.007 & -1 \\
\hline 04АТі109-58.1 & 4.42 & 2.2 & .2599 & 1.0 & .463 & 1438.3 & 14.1 & 2004.1 & 34.8 & 2004.1 & 34.8 & 0.017 & 35 \\
\hline 04ATi109-50.1 & 7.08 & 0.5 & .3848 & 0.4 & .702 & 2090.4 & 7.9 & 2144.1 & 6.6 & 2144.1 & 6.6 & 0.003 & 2 \\
\hline 04АТі109-37.1 & 13.30 & 0.9 & .5233 & 0.7 & .776 & 2721.1 & 20.7 & 2691.9 & 8.9 & 2691.9 & 8.9 & 0.003 & -1 \\
\hline
\end{tabular}


Table 2. U-Pb analytical data for detrital and igneous zircons, identified by sample number and lab.—Continued

\begin{tabular}{|c|c|c|c|c|c|c|c|c|c|c|c|c|c|}
\hline Spot name & $207 r / 235$ & $\begin{array}{c}1 \sigma \\
\text { error } \\
(\%)\end{array}$ & $206 r / 238$ & $\begin{array}{c}1 \sigma \\
\text { error } \\
(\%)\end{array}$ & $\begin{array}{c}\text { Error } \\
\text { cor- } \\
\text { relation }\end{array}$ & $\begin{array}{c}207 \text { corr } \\
206 / 238 \\
\text { age } \\
\text { (Ma) }\end{array}$ & $\begin{array}{c}1 \sigma \\
\text { error } \\
\text { (m.y.) }\end{array}$ & $\begin{array}{c}204 \text { corr } \\
207 / 206 \\
\text { Age } \\
(\mathrm{Ma})\end{array}$ & $\begin{array}{c}1 \sigma \\
\text { error } \\
\text { (m.y.) }\end{array}$ & $\begin{array}{l}\text { Best } \\
\text { age } \\
(\mathrm{Ma})\end{array}$ & $\begin{array}{c}1 \sigma \\
\text { error } \\
\text { (m.y.) }\end{array}$ & Error/age & $\begin{array}{c}\text { Dis- } \\
\text { cordance } \\
(\%)\end{array}$ \\
\hline ATI103-41.1 & 0.07 & 5.7 & .0097 & 1.5 & .272 & 61.3 & 1.0 & 406.6 & 122.5 & 61.3 & 1.0 & 0.016 & 557 \\
\hline ATI103-7.1 & 0.04 & 73.5 & .0106 & 2.9 & .039 & 69.9 & 1.1 & & & 69.9 & 1.1 & 0.016 & \\
\hline ATI103-30.1 & 0.07 & 11.1 & .0109 & 1.2 & .110 & 70.1 & 0.8 & -62.9 & 269.3 & 70.1 & 0.8 & 0.011 & -190 \\
\hline ATI103-12.1 & 0.07 & 18.2 & .0113 & 2.4 & .131 & 72.8 & 1.7 & -175.6 & 448.7 & 72.8 & 1.7 & 0.023 & -343 \\
\hline ATI103-2.1 & 0.07 & 4.4 & .0114 & 0.7 & .153 & 73.6 & 0.5 & -64.9 & 105.9 & 73.6 & 0.5 & 0.007 & -188 \\
\hline ATI103-1 & 0.07 & 17.2 & .0115 & 2.4 & .137 & 74.0 & 1.7 & -97.3 & 418.8 & 74.0 & 1.7 & 0.023 & -232 \\
\hline ATI103-37.1 & 0.06 & 15.1 & .0115 & 1.4 & .092 & 74.2 & 0.9 & -334.4 & 386.5 & 74.2 & 0.9 & 0.012 & -555 \\
\hline ATI103-11.1 & 0.08 & 3.5 & .0117 & 0.9 & .250 & 74.5 & 0.7 & 178.8 & 79.7 & 74.5 & 0.7 & 0.009 & 139 \\
\hline ATI103-14.1 & 0.08 & 40.0 & .0117 & 2.9 & .072 & 74.9 & 1.3 & 241.7 & 919.2 & 74.9 & 1.3 & 0.017 & 221 \\
\hline ATI103-44.1 & 0.08 & 2.9 & .0118 & 0.8 & .266 & 75.0 & 0.6 & 263.0 & 63.1 & 75.0 & 0.6 & 0.008 & 249 \\
\hline ATI103-43.1 & 0.07 & 9.2 & .0117 & 1.3 & .142 & 75.4 & 1.0 & -52.9 & 221.2 & 75.4 & 1.0 & 0.013 & -170 \\
\hline ATI103-33.1 & 0.06 & 33.5 & .0116 & 2.8 & .083 & 75.5 & 1.9 & -481.6 & 886.0 & 75.5 & 1.9 & 0.025 & -746 \\
\hline ATI103-28.1 & 0.08 & 3.3 & .0118 & 0.8 & .231 & 75.6 & 0.6 & 185.1 & 74.4 & 75.6 & 0.6 & 0.008 & 144 \\
\hline ATI103-19.1 & 0.08 & 2.8 & .0119 & 0.7 & .262 & 75.8 & 0.6 & 192.7 & 62.4 & 75.8 & 0.6 & 0.007 & 154 \\
\hline ATI103-38.1 & & & .0109 & 1.8 & & 76.1 & 0.7 & & & 76.1 & 0.7 & 0.010 & \\
\hline ATI103-18.1 & 0.06 & 56.6 & .0117 & 3.2 & .056 & 76.2 & 1.6 & -550.7 & 1520.5 & 76.2 & 1.6 & 0.021 & -832 \\
\hline ATI103-4.1 & 0.06 & 13.2 & .0118 & 1.1 & .081 & 76.5 & 0.7 & -364.2 & 341.2 & 76.5 & 0.7 & 0.009 & -580 \\
\hline ATI103-29.1 & 0.07 & 23.4 & .0119 & 1.9 & .081 & 76.8 & 1.2 & -267.5 & 593.3 & 76.8 & 1.2 & 0.016 & -451 \\
\hline ATI103-17.1 & 0.10 & 8.9 & .0122 & 2.5 & .283 & 76.9 & 2.0 & 582.3 & 185.6 & 76.9 & 2.0 & 0.026 & 646 \\
\hline ATI103-32.1 & 0.12 & 7.0 & .0124 & 2.2 & .310 & 77.3 & 1.7 & 977.5 & 135.6 & 77.3 & 1.7 & 0.023 & 1127 \\
\hline ATI103-34.1 & 0.04 & 84.3 & .0118 & 3.4 & .041 & 77.9 & 1.9 & & & 77.9 & 1.9 & 0.024 & \\
\hline ATI103-3.1 & & & .0111 & 5.4 & & 78.0 & 2.3 & & & 78.0 & 2.3 & 0.029 & \\
\hline ATI103-5.1 & 0.10 & 19.7 & .0124 & 2.8 & .139 & 78.8 & 2.0 & 455.3 & 433.7 & 78.8 & 2.0 & 0.026 & 472 \\
\hline ATI103-31.1 & 0.07 & 31.3 & .0122 & 2.3 & .073 & 79.2 & 1.6 & -424.5 & 819.3 & 79.2 & 1.6 & 0.020 & -642 \\
\hline ATI103-40.1 & 0.05 & 39.5 & .0121 & 2.2 & .055 & 79.6 & 1.4 & & & 79.6 & 1.4 & 0.018 & \\
\hline ATI103-22.1 & 0.08 & 9.6 & .0125 & 1.1 & .117 & 80.4 & 0.8 & -44.9 & 232.1 & 80.4 & 0.8 & 0.010 & -156 \\
\hline ATI103-25.1 & 0.08 & 31.2 & .0125 & 3.4 & .108 & 80.6 & 2.5 & -73.3 & 758.5 & 80.6 & 2.5 & 0.031 & -191 \\
\hline ATI103-42.1 & 0.07 & 15.5 & .0126 & 1.7 & .110 & 81.3 & 1.3 & -189.1 & 386.4 & 81.3 & 1.3 & 0.016 & -334 \\
\hline ATI103-24.1 & 0.07 & 17.7 & .0126 & 1.7 & .095 & 81.5 & 1.2 & -214.1 & 443.7 & 81.5 & 1.2 & 0.015 & -364 \\
\hline ATI103-26.1 & & & .0121 & 3.8 & & 81.9 & 1.8 & & & 81.9 & 1.8 & 0.021 & \\
\hline ATI103-8.1 & 0.09 & 4.7 & .0129 & 0.7 & .143 & 82.5 & 0.6 & 111.4 & 110.3 & 82.5 & 0.6 & 0.007 & 35 \\
\hline ATI103-13.1 & 0.04 & 97.6 & .0126 & 3.4 & .035 & 83.5 & 2.2 & & & 83.5 & 2.2 & 0.027 & \\
\hline ATI103-20.1 & 0.11 & 6.5 & .0135 & 1.9 & .287 & 85.0 & 1.6 & 597.8 & 135.1 & 85.0 & 1.6 & 0.019 & 592 \\
\hline ATI103-27.1 & 0.09 & 4.6 & .0137 & 1.2 & .265 & 87.2 & 1.1 & 213.2 & 102.7 & 87.2 & 1.1 & 0.012 & 144 \\
\hline ATI103-6.1 & 0.08 & 14.7 & .0136 & 1.6 & .112 & 87.6 & 1.3 & -187.7 & 365.9 & 87.6 & 1.3 & 0.015 & -316 \\
\hline ATI103-21.1 & 0.07 & 48.9 & .0135 & 3.1 & .064 & 87.9 & 2.2 & -693.7 & 1353.9 & 87.9 & 2.2 & 0.025 & -902 \\
\hline ATI103-23.1 & 0.09 & 9.9 & .0138 & 1.7 & .173 & 88.1 & 1.5 & 70.6 & 231.7 & 88.1 & 1.5 & 0.017 & -20 \\
\hline ATI103-36.1 & 0.05 & 38.5 & .0134 & 1.9 & .049 & 88.2 & 1.3 & & & 88.2 & 1.3 & 0.015 & \\
\hline ATI103-16.1 & 0.10 & 9.3 & .0144 & 1.7 & .182 & 91.9 & 1.5 & 195.8 & 211.5 & 91.9 & 1.5 & 0.017 & 112 \\
\hline ATI103-39.1 & & & .0133 & 2.5 & & 92.0 & 1.4 & & & 92.0 & 1.4 & 0.015 & \\
\hline ATI103-15.1 & 0.10 & 4.8 & .0145 & 1.3 & .263 & 92.6 & 1.2 & 132.8 & 108.1 & 92.6 & 1.2 & 0.013 & 43 \\
\hline ATI103-35.1 & 0.11 & 7.1 & .0151 & 1.9 & .271 & 96.1 & 1.9 & 342.3 & 155.4 & 96.1 & 1.9 & 0.020 & 254 \\
\hline ATI103-9.1 & 0.12 & 10.3 & .0175 & 1.9 & .183 & 111.3 & 2.1 & 206.0 & 235.3 & 111.3 & 2.1 & 0.019 & 85 \\
\hline ATI103-10.1 & 0.22 & 3.6 & .0287 & 1.1 & .302 & 180.6 & 2.0 & 467.9 & 75.5 & 180.6 & 2.0 & 0.011 & 157 \\
\hline \multicolumn{14}{|c|}{ 88ADw122x, clast, SHRIMP-RG, mean 206Pb/238U age: $181.8 \pm 2.1 \mathrm{Ma}$} \\
\hline Spot name & $207 r / 235$ & $\begin{array}{c}1 \sigma \\
\text { error } \\
(\%)\end{array}$ & $206 \mathrm{r} / 238$ & $\begin{array}{c}1 \sigma \\
\text { error } \\
(\%)\end{array}$ & $\begin{array}{c}\text { Error } \\
\text { cor- } \\
\text { relation }\end{array}$ & $\begin{array}{c}207 \text { corr } \\
206 / 238 \\
\text { age } \\
(\mathrm{Ma})\end{array}$ & $\begin{array}{c}1 \sigma \\
\text { error } \\
\text { (m.y.) }\end{array}$ & $\begin{array}{c}204 \text { corr } \\
207 / 206 \\
\text { Age } \\
(\mathrm{Ma})\end{array}$ & $\begin{array}{c}1 \sigma \\
\text { error } \\
\text { (m.y.) }\end{array}$ & $\begin{array}{l}\text { Best } \\
\text { age } \\
(\mathrm{Ma})\end{array}$ & $\begin{array}{c}1 \sigma \\
\text { error } \\
\text { (m.y.) }\end{array}$ & Error/age & $\begin{array}{c}\text { Dis- } \\
\text { cordance } \\
(\%)\end{array}$ \\
\hline $88 A D w 122 x-1$ & 0.15 & 16.1 & .0274 & 2.1 & .128 & 176.2 & 3.4 & -303 & 408 & 176.2 & 3.4 & & \\
\hline $88 A D w 122 x-2$ & 0.20 & 6.4 & .0279 & 2.2 & .343 & 176.9 & 3.9 & 293 & 137 & 176.9 & 3.9 & & \\
\hline $88 A D w 122 x-3$ & 0.18 & 7.1 & .0279 & 2.0 & .278 & 177.8 & 3.5 & 54 & 163 & 177.8 & 3.5 & & \\
\hline $88 A D w 122 x-4$ & 0.17 & 7.1 & .0280 & 1.7 & .240 & 179.2 & 3.0 & -129 & 169 & 179.2 & 3.0 & & \\
\hline $88 A D w 122 x-5$ & 0.17 & 8.8 & .0285 & 1.7 & .197 & 182.3 & 3.1 & -151 & 213 & 182.3 & 3.1 & & \\
\hline $88 A D w 122 x-6$ & 0.21 & 5.1 & .0288 & 1.9 & .372 & 182.8 & 3.5 & 291 & 108 & 182.8 & 3.5 & & \\
\hline $88 A D w 122 x-7$ & 0.18 & 5.7 & .0287 & 1.6 & .279 & 183.7 & 2.9 & -38 & 133 & 183.7 & 2.9 & & \\
\hline $88 A D w 122 x-8$ & 0.17 & 10.6 & .0287 & 1.7 & .163 & 183.8 & 3.0 & -195 & 261 & 183.8 & 3.0 & & \\
\hline $88 A D w 122 x-9$ & 0.21 & 3.2 & .0297 & 1.5 & .462 & 188.3 & 2.7 & 204 & 65 & 188.3 & 2.7 & & \\
\hline \multicolumn{14}{|c|}{ 88ADw122w, clast, SHRIMP-RG, mean 206Pb/238U age: $179.2 \pm 2.8 \mathrm{Ma}$} \\
\hline Spot name & $207 r / 235$ & $\begin{array}{c}1 \sigma \\
\text { error } \\
(\%)\end{array}$ & $206 r / 238$ & $\begin{array}{c}1 \sigma \\
\text { error } \\
(\%)\end{array}$ & $\begin{array}{c}\text { Error } \\
\text { cor- } \\
\text { relation }\end{array}$ & $\begin{array}{c}207 \text { corr } \\
206 / 238 \\
\text { age } \\
(\mathrm{Ma})\end{array}$ & $\begin{array}{c}1 \sigma \\
\text { error } \\
\text { (m.y.) }\end{array}$ & $\begin{array}{c}204 \text { corr } \\
207 / 206 \\
\text { Age } \\
(\mathrm{Ma})\end{array}$ & $\begin{array}{c}1 \sigma \\
\text { error } \\
\text { (m.y.) }\end{array}$ & $\begin{array}{l}\text { Best } \\
\text { age } \\
(\mathrm{Ma})\end{array}$ & $\begin{array}{c}1 \sigma \\
\text { error } \\
\text { (m.y.) }\end{array}$ & Error/age & $\begin{array}{c}\text { Dis- } \\
\text { cordance } \\
(\%)\end{array}$ \\
\hline $88 A D w 122 w-1$ & 0.20 & 6.9 & .0274 & 2.4 & .349 & 173.5 & 4.2 & 345 & 146 & 173.5 & 4.2 & & \\
\hline $88 A D w 122 w-2$ & 0.17 & 10.4 & .0271 & 2.3 & .225 & 173.7 & 4.0 & -79 & 248 & 173.7 & 4.0 & & \\
\hline $88 A D w 122 w-3$ & 0.12 & 32.7 & .0270 & 2.5 & & 175.5 & 3.8 & -1013 & 970 & 175.5 & 3.8 & & \\
\hline $88 A D w 122 w-4$ & 0.19 & 6.2 & .0279 & 2.2 & .351 & 177.4 & 3.9 & 217 & 135 & 177.4 & 3.9 & & \\
\hline
\end{tabular}


Table 2

Table 2. U-Pb analytical data for detrital and igneous zircons, identified by sample number and lab.-Continued

\begin{tabular}{|c|c|c|c|c|c|c|c|c|c|c|c|c|c|}
\hline $88 A D w 122 w-5$ & 0.21 & 7.1 & .0283 & 2.5 & .349 & 178.5 & 4.5 & 408 & 150 & 178.5 & 4.5 & & \\
\hline $88 A D w 122 w-6$ & 0.19 & 6.7 & .0286 & 2.3 & .346 & 181.9 & 4.2 & 141 & 147 & 181.9 & 4.2 & & \\
\hline $88 A D w 122 w-7$ & 0.18 & 6.2 & .0285 & 2.1 & .334 & 182.2 & 3.8 & -77 & 142 & 182.2 & 3.8 & & \\
\hline $88 A D w 122 w-8$ & 0.16 & 17.5 & .0288 & 3.0 & .170 & 184.6 & 5.4 & -258 & 437 & 184.6 & 5.4 & & \\
\hline 88ADw122w-9 & 0.18 & 10.2 & .0294 & 2.2 & .214 & 188.2 & 4.1 & -80 & 243 & 188.2 & 4.1 & & \\
\hline \multicolumn{14}{|c|}{ 92AKu18, clast, SHRIMP-RG, mean 206Pb/238U age: $221.8 \pm 0.6 \mathrm{Ma}$} \\
\hline Spot name & $207 r / 235$ & $\begin{array}{c}1 \sigma \\
\text { error } \\
(\%)\end{array}$ & $206 r / 238$ & $\begin{array}{c}1 \sigma \\
\text { error } \\
(\%)\end{array}$ & $\begin{array}{l}\text { Error } \\
\text { cor- } \\
\text { relation }\end{array}$ & $\begin{array}{c}207 \text { corr } \\
206 / 238 \\
\text { age } \\
\text { (Ma) } \\
\end{array}$ & $\begin{array}{l}1 \sigma \\
\text { error } \\
\text { (m.y.) }\end{array}$ & $\begin{array}{c}204 \text { corr } \\
207 / 206 \\
\text { Age } \\
\text { (Ma) }\end{array}$ & $\begin{array}{c}1 \sigma \\
\text { error } \\
\text { (m.y.) }\end{array}$ & $\begin{array}{l}\text { Best } \\
\text { age } \\
\text { (Ma) }\end{array}$ & $\begin{array}{c}1 \sigma \\
\text { error } \\
\text { (m.y.) }\end{array}$ & Error/age & $\begin{array}{c}\text { Dis- } \\
\text { cordance } \\
(\%)\end{array}$ \\
\hline 92AKu18-3 & 0.21 & 2.1 & .0301 & 0.3 & .137 & 191.0 & 0.6 & 251.4 & 48.6 & 191.0 & 0.6 & & \\
\hline 92AKu18-4 & 0.23 & 2.0 & .0327 & 0.3 & .158 & 207.2 & 0.7 & 265.7 & 45.4 & 207.2 & 0.7 & & \\
\hline 92AKu18-5 & 0.23 & 3.5 & .0333 & 0.3 & .091 & 210.7 & 0.7 & 245.9 & 80.5 & 210.7 & 0.7 & & \\
\hline 92AKu18-6 & 0.24 & 1.2 & .0346 & 0.3 & .248 & 219.6 & 0.6 & 188.2 & 26.6 & 219.6 & 0.6 & & \\
\hline 92AKu18-7 & 0.26 & 2.5 & .0349 & 0.4 & .145 & 220.5 & 0.8 & 345.8 & 56.1 & 220.5 & 0.8 & & \\
\hline 92AKu18-8 & 0.25 & 1.3 & .0349 & 0.3 & .229 & 220.7 & 0.7 & 273.6 & 29.8 & 220.7 & 0.7 & & \\
\hline 92AKu18-9 & 0.25 & 1.6 & .0350 & 0.3 & .212 & 221.3 & 0.8 & 268.9 & 36.8 & 221.3 & 0.8 & & \\
\hline 92AKu18-10 & 0.24 & 2.3 & .0350 & 0.6 & .251 & 221.7 & 1.3 & 179.5 & 52.6 & 221.7 & 1.3 & & \\
\hline 92AKu18-11 & 0.24 & 1.7 & .0350 & 0.3 & .205 & 222.0 & 0.8 & 211.2 & 38.3 & 222.0 & 0.8 & & \\
\hline 92AKu18-12 & 0.24 & 1.3 & .0351 & 0.4 & .308 & 222.7 & 0.9 & 215.3 & 27.8 & 222.7 & 0.9 & & \\
\hline 92AKu18-13 & 0.24 & 2.0 & .0355 & 0.5 & .245 & 224.9 & 1.1 & 187.0 & 44.1 & 224.9 & 1.1 & & \\
\hline 92AKu18-14 & 0.26 & 1.4 & .0359 & 0.4 & .308 & 226.6 & 1.0 & 309.9 & 29.9 & 226.6 & 1.0 & & \\
\hline 92AKu18-15 & 0.24 & 3.3 & .0357 & 0.6 & .178 & 226.8 & 1.3 & 91.6 & 75.9 & 226.8 & 1.3 & & \\
\hline \multicolumn{14}{|c|}{$88 \mathrm{ADw} 115 \mathrm{dz}$, detrital zircons, $\mathrm{n}=61$ of 90 , Univ. of British Columbia } \\
\hline Analysis \# & 207/235 & $\begin{array}{c}1 \sigma \\
\text { error } \\
(\%)\end{array}$ & $206 / 238$ & $\begin{array}{c}1 \sigma \\
\text { error } \\
(\%)\end{array}$ & $\begin{array}{c}\text { Error } \\
\text { cor- } \\
\text { relation }\end{array}$ & $\begin{array}{c}206 / 238 \\
\text { age }\end{array}$ & $\begin{array}{c}1 \sigma \\
\text { error } \\
(\mathrm{Ma})\end{array}$ & $\begin{array}{c}\text { 207/206 } \\
\text { age }\end{array}$ & $\begin{array}{l}1 \sigma \\
\text { error } \\
\text { (Ma) }\end{array}$ & $\begin{array}{l}\text { Best } \\
\text { age } \\
(\mathrm{Ma})\end{array}$ & $\begin{array}{l}1 \sigma \\
\text { error } \\
(\mathrm{Ma})\end{array}$ & Error/age & $\begin{array}{c}\text { Dis- } \\
\text { cordance } \\
(\%)\end{array}$ \\
\hline 88ADw115V87 & 0.06713 & 0.00823 & 0.01076 & 0.00028 & 0.2123 & 69.0 & 1.8 & 74.6 & 271.7 & 69.0 & 1.8 & 0.026 & 8 \\
\hline 88ADW115V45 & 0.10416 & 0.01093 & 0.01155 & 0.00032 & 0.2640 & 74.0 & 2.1 & 646.0 & 213.9 & 74.0 & 2.1 & 0.028 & 89 \\
\hline 88ADw115V17 & 0.08378 & 0.00381 & 0.01176 & 0.00017 & 0.3179 & 75.4 & 1.1 & 163.0 & 105.2 & 75.4 & 1.1 & 0.015 & 54 \\
\hline 88ADw115V47 & 0.08513 & 0.01125 & 0.01194 & 0.00035 & 0.2218 & 76.5 & 2.2 & 81.3 & 290.2 & 76.5 & 2.2 & 0.029 & 6 \\
\hline 88ADw115V57 & 0.07835 & 0.00474 & 0.01206 & 0.00019 & 0.2604 & 77.3 & 1.2 & 81.0 & 140.4 & 77.3 & 1.2 & 0.016 & 5 \\
\hline 88ADw115V58 & 0.07989 & 0.00737 & 0.01211 & 0.00025 & 0.2238 & 77.6 & 1.6 & 83.2 & 208.5 & 77.6 & 1.6 & 0.021 & 7 \\
\hline 88ADW115V36 & 0.09281 & 0.00922 & 0.01214 & 0.00028 & 0.2322 & 77.8 & 1.8 & 356.8 & 212.4 & 77.8 & 1.8 & 0.023 & 78 \\
\hline 88ADw115V11 & 0.07953 & 0.00246 & 0.01217 & 0.00011 & 0.2922 & 78.0 & 0.7 & 86.4 & 74.0 & 78.0 & 0.7 & 0.009 & 10 \\
\hline 88ADw115V30 & 0.07796 & 0.00772 & 0.01243 & 0.00036 & 0.2925 & 79.6 & 2.3 & 82.8 & 224.3 & 79.6 & 2.3 & 0.029 & 4 \\
\hline 88ADw115V23 & 0.09016 & 0.009 & 0.01245 & 0.00039 & 0.3138 & 79.7 & 2.5 & 79.2 & 226.0 & 79.7 & 2.5 & 0.031 & -1 \\
\hline 88ADW115V90 & 0.09814 & 0.0042 & 0.01252 & 0.00016 & 0.2986 & 80.2 & 1.0 & 523.9 & 22.8 & 80.2 & 1.0 & 0.012 & 85 \\
\hline 88ADW115V71 & 0.08223 & 0.02796 & 0.01306 & 0.00074 & 0.1666 & 83.6 & 4.7 & 86.8 & 658.2 & 83.6 & 4.7 & 0.057 & 4 \\
\hline 88ADW115V13 & 0.09324 & 0.00385 & 0.0131 & 0.00016 & 0.2958 & 83.9 & 1.0 & 263.4 & 93.6 & 83.9 & 1.0 & 0.012 & 68 \\
\hline 88ADw115V91 & 0.08779 & 0.0069 & 0.01331 & 0.00031 & 0.2963 & 85.2 & 2.0 & 77.9 & 180.3 & 85.2 & 2.0 & 0.023 & -9 \\
\hline 88ADw115V29 & 0.08671 & 0.00852 & 0.01333 & 0.00032 & 0.2443 & 85.3 & 2.0 & 82.4 & 221.2 & 85.3 & 2.0 & 0.024 & -4 \\
\hline 88ADw115V42 & 0.09294 & 0.00406 & 0.01352 & 0.0002 & 0.3386 & 86.6 & 1.3 & 328.7 & 98.0 & 86.6 & 1.3 & 0.014 & 74 \\
\hline 88ADw115V40 & 0.08623 & 0.00366 & 0.01364 & 0.00019 & 0.3282 & 87.3 & 1.2 & 89.1 & 100.4 & 87.3 & 1.2 & 0.014 & 2 \\
\hline 88ADw115V79 & 0.09393 & 0.00166 & 0.01428 & 0.00009 & 0.3566 & 91.4 & 0.6 & 92.5 & 42.8 & 91.4 & 0.6 & 0.006 & 1 \\
\hline 88ADw115V99 & 0.09529 & 0.01295 & 0.01442 & 0.00039 & 0.1990 & 92.3 & 2.5 & 97.5 & 296.5 & 92.3 & 2.5 & 0.027 & 5 \\
\hline 188ADW115V73 & 0.11405 & 0.02051 & 0.01442 & 0.00062 & 0.2391 & 92.3 & 3.9 & 601.1 & 351.4 & 92.3 & 3.9 & 0.042 & 85 \\
\hline 88ADw115V94 & 0.16954 & 0.05989 & 0.01442 & 0.00115 & 0.2258 & 92.3 & 7.3 & 1516.0 & 555.1 & 92.3 & 7.3 & 0.079 & 94 \\
\hline 88ADw115V27 & 0.09564 & 0.00622 & 0.0145 & 0.00026 & 0.2757 & 92.8 & 1.7 & 84.5 & 150.1 & 92.8 & 1.7 & 0.018 & -10 \\
\hline 88ADw115V82 & 0.09613 & 0.00413 & 0.01479 & 0.00021 & 0.3305 & 94.6 & 1.4 & 91.3 & 101.3 & 94.6 & 1.4 & 0.014 & -4 \\
\hline 88ADW115V38 & 0.10588 & 0.00154 & 0.01594 & 0.00008 & 0.3451 & 101.8 & 0.5 & 201.9 & 33.7 & 101.8 & 0.5 & 0.005 & 50 \\
\hline 88ADW115V97 & 0.11811 & 0.0048 & 0.01723 & 0.00021 & 0.2999 & 110.1 & 1.4 & 220.2 & 92.0 & 110.1 & 1.4 & 0.012 & 50 \\
\hline 88ADw115V31 & 0.11052 & 0.00382 & 0.01747 & 0.00018 & 0.2981 & 111.7 & 1.2 & 105.7 & 80.5 & 111.7 & 1.2 & 0.010 & -6 \\
\hline 88ADw115V77 & 0.12525 & 0.00333 & 0.02016 & 0.00018 & 0.3358 & 128.7 & 1.1 & 123.2 & 61.7 & 128.7 & 1.1 & 0.009 & -4 \\
\hline 88ADw115V68 & 0.14307 & 0.02675 & 0.02075 & 0.00074 & 0.1907 & 132.4 & 4.7 & 129.4 & 388.4 & 132.4 & 4.7 & 0.035 & -2 \\
\hline $88 \mathrm{ADw} 115 \mathrm{~V} 28$ & 0.14227 & 0.00819 & 0.02083 & 0.00031 & 0.2585 & 132.9 & 1.9 & 137.1 & 130.0 & 132.9 & 1.9 & 0.015 & 3 \\
\hline 88ADw115V65 & 0.14005 & 0.0093 & 0.02184 & 0.0004 & 0.2758 & 139.3 & 2.6 & 142.3 & 149.1 & 139.3 & 2.6 & 0.018 & 2 \\
\hline 88ADW $115 V 14$ & 0.16044 & 0.00783 & 0.02187 & 0.00028 & 0.2623 & 139.5 & 1.8 & 247.0 & 108.3 & 139.5 & 1.8 & 0.013 & 44 \\
\hline 88ADw115V84 & 0.15581 & 0.01016 & 0.02204 & 0.00038 & 0.2644 & 140.6 & 2.4 & 138.7 & 146.1 & 140.6 & 2.4 & 0.017 & -1 \\
\hline 88ADw115V74 & 0.14505 & 0.02597 & 0.02213 & 0.0007 & 0.1767 & 141.1 & 4.4 & 151.4 & 373.1 & 141.1 & 4.4 & 0.031 & 7 \\
\hline 88ADw115V15 & 0.14746 & 0.01065 & 0.0222 & 0.00047 & 0.2931 & 141.6 & 2.9 & 138.3 & 161.3 & 141.6 & 2.9 & 0.021 & -2 \\
\hline $88 \mathrm{ADw} 115 \mathrm{~V} 51$ & 0.15649 & 0.01265 & 0.02267 & 0.0005 & 0.2728 & 144.5 & 3.2 & 145.2 & 178.8 & 144.5 & 3.2 & 0.022 & 0 \\
\hline 88ADw115V88 & 0.1651 & 0.01131 & 0.0228 & 0.0004 & 0.2561 & 145.3 & 2.5 & 146.7 & 152.7 & 145.3 & 2.5 & 0.017 & 1 \\
\hline 88ADw115V62 & 0.15858 & 0.01301 & 0.02299 & 0.00043 & 0.2280 & 146.5 & 2.7 & 156.5 & 180.9 & 146.5 & 2.7 & 0.018 & 6 \\
\hline 88ADw115V19 & 0.15413 & 0.00423 & 0.02307 & 0.00021 & 0.3317 & 147.0 & 1.3 & 149.6 & 62.8 & 147.0 & 1.3 & 0.009 & 2 \\
\hline $88 \mathrm{ADw} 115 \mathrm{~V} 20$ & 0.15203 & 0.00837 & 0.0232 & 0.00036 & 0.2819 & 147.8 & 2.3 & 143.5 & 124.1 & 147.8 & 2.3 & 0.015 & -3 \\
\hline 88ADw115V18 & 0.16061 & 0.00736 & 0.02327 & 0.0003 & 0.2813 & 148.3 & 1.9 & 142.9 & 103.8 & 148.3 & 1.9 & 0.013 & -4 \\
\hline 88ADw115V22 & 0.1738 & 0.01546 & 0.02336 & 0.00056 & 0.2695 & 148.8 & 3.5 & 142.7 & 195.0 & 148.8 & 3.5 & 0.024 & -4 \\
\hline 88ADw115V76 & 0.17951 & 0.02939 & 0.02352 & 0.00076 & 0.1974 & 149.9 & 4.8 & 401.4 & 329.7 & 149.9 & 4.8 & 0.032 & 63 \\
\hline 88ADW115V100 & 0.25548 & 0.07905 & 0.02364 & 0.0016 & 0.2187 & 150.6 & 10.1 & 1096.9 & 517.8 & 150.6 & 10.1 & 0.067 & 86 \\
\hline
\end{tabular}


Table 2. U-Pb analytical data for detrital and igneous zircons, identified by sample number and lab.-Continued

\begin{tabular}{|c|c|c|c|c|c|c|c|c|c|c|c|c|c|}
\hline 88ADw115V41 & 0.15636 & 0.00988 & 0.02378 & 0.00037 & 0.2462 & 151.5 & 2.3 & 148.6 & 141.4 & 151.5 & 2.3 & 0.015 & -2 \\
\hline 88ADw115V53 & 0.16839 & 0.0067 & 0.0238 & 0.00028 & 0.2957 & 151.7 & 1.8 & 152.5 & 89.9 & 151.7 & 1.8 & 0.012 & 1 \\
\hline 88ADw115V55 & 0.17854 & 0.01542 & 0.02384 & 0.00053 & 0.2574 & 151.9 & 3.3 & 152.9 & 189.2 & 151.9 & 3.3 & 0.022 & 1 \\
\hline 88ADw115V56 & 0.16326 & 0.01279 & 0.02401 & 0.00046 & 0.2446 & 153.0 & 2.9 & 149.5 & 173.4 & 153.0 & 2.9 & 0.019 & -2 \\
\hline 88ADW115V89 & 0.2992 & 0.05676 & 0.02406 & 0.00149 & 0.3264 & 153.3 & 9.4 & 1397.0 & 322.7 & 153.3 & 9.4 & 0.061 & 89 \\
\hline 88ADw115V101 & 0.20723 & 0.0108 & 0.02413 & 0.00039 & 0.3101 & 153.7 & 2.5 & 608.7 & 107.7 & 153.7 & 2.5 & 0.016 & 75 \\
\hline 88ADw115V60 & 0.16112 & 0.01182 & 0.02415 & 0.00044 & 0.2484 & 153.8 & 2.8 & 147.1 & 163.0 & 153.8 & 2.8 & 0.018 & -5 \\
\hline 88ADW115V49 & 0.17329 & 0.09251 & 0.02436 & 0.00193 & 0.1484 & 155.1 & 12.2 & 149.3 & 222.0 & 155.1 & 12.2 & 0.078 & -4 \\
\hline 88ADw115V81 & 0.17206 & 0.00633 & 0.02438 & 0.00028 & 0.3122 & 155.3 & 1.8 & 161.1 & 83.0 & 155.3 & 1.8 & 0.011 & 4 \\
\hline 88ADw115V92 & 0.07331 & 0.31133 & 0.02466 & 0.00411 & 0.0392 & 157.1 & 25.9 & 0.1 & 1525.0 & 157.1 & 25.9 & 0.165 & -157000 \\
\hline 88ADw115V32 & 0.16446 & 0.00498 & 0.02474 & 0.00025 & 0.3337 & 157.6 & 1.6 & 163.2 & 68.8 & 157.6 & 1.6 & 0.010 & 3 \\
\hline 88ADw115V75 & 0.15969 & 0.01004 & 0.02493 & 0.00036 & 0.2297 & 158.7 & 2.3 & 164.2 & 140.2 & 158.7 & 2.3 & 0.014 & 3 \\
\hline 88ADw115V16 & 0.17339 & 0.00952 & 0.02504 & 0.00036 & 0.2619 & 159.4 & 2.3 & 153.1 & 123.0 & 159.4 & 2.3 & 0.014 & -4 \\
\hline 88ADw115V50 & 0.16502 & 0.00931 & 0.02539 & 0.00033 & 0.2304 & 161.6 & 2.1 & 152.8 & 126.5 & 161.6 & 2.1 & 0.013 & -6 \\
\hline 88ADw115V37 & 0.16931 & 0.00986 & 0.0254 & 0.0004 & 0.2704 & 161.7 & 2.5 & 153.4 & 130.3 & 161.7 & 2.5 & 0.016 & -5 \\
\hline 88ADw115V102 & 0.17341 & 0.01972 & 0.02542 & 0.00059 & 0.2041 & 161.8 & 3.7 & 164.2 & 244.9 & 161.8 & 3.7 & 0.023 & 1 \\
\hline 88ADw115V83 & 0.17351 & 0.01317 & 0.02544 & 0.0005 & 0.2589 & 161.9 & 3.2 & 172.9 & 167.0 & 161.9 & 3.2 & 0.019 & 6 \\
\hline 88ADw115V63 & 0.16755 & 0.00732 & 0.02549 & 0.00035 & 0.3143 & 162.3 & 2.2 & 158.5 & 98.4 & 162.3 & 2.2 & 0.014 & -2 \\
\hline 88ADw115V35 & 0.17938 & 0.00609 & 0.02553 & 0.00024 & 0.2769 & 162.5 & 1.5 & 172.1 & 76.7 & 162.5 & 1.5 & 0.009 & 6 \\
\hline 88ADw115V85 & 0.16967 & 0.00429 & 0.02561 & 0.0002 & 0.3089 & 163.0 & 1.3 & 164.0 & 57.3 & 163.0 & 1.3 & 0.008 & 1 \\
\hline 88ADW115V66 & 0.16599 & 0.02123 & 0.02599 & 0.00055 & 0.1655 & 165.4 & 3.5 & 0.1 & 214.4 & 165.4 & 3.5 & 0.021 & -165300 \\
\hline 88ADw115V26 & 0.20078 & 0.01804 & 0.02633 & 0.00058 & 0.2452 & 167.6 & 3.6 & 448.7 & 186.9 & 167.6 & 3.6 & 0.022 & 63 \\
\hline 88ADw115V33 & 0.17383 & 0.01265 & 0.0265 & 0.00054 & 0.2800 & 168.6 & 3.4 & 159.7 & 160.9 & 168.6 & 3.4 & 0.020 & -6 \\
\hline 88ADw115V86 & 0.18554 & 0.01258 & 0.02651 & 0.00045 & 0.2504 & 168.7 & 2.9 & 176.2 & 149.4 & 168.7 & 2.9 & 0.017 & 4 \\
\hline 88ADw115V98 & 0.19891 & 0.0296 & 0.02677 & 0.00092 & 0.2309 & 170.3 & 5.8 & 161.6 & 311.4 & 170.3 & 5.8 & 0.034 & -5 \\
\hline 88ADW115V10 & 0.2046 & 0.02051 & 0.027 & 0.00065 & 0.2402 & 171.7 & 4.1 & 425.4 & 207.7 & 171.7 & 4.1 & 0.024 & 60 \\
\hline 88ADw115V39 & 0.18949 & 0.00467 & 0.02783 & 0.00023 & 0.3353 & 176.9 & 1.4 & 189.4 & 55.4 & 176.9 & 1.4 & 0.008 & 7 \\
\hline 88ADW115V67 & 0.3021 & 0.06687 & 0.02791 & 0.00145 & 0.2347 & 177.4 & 9.1 & 1135.9 & 382.7 & 177.4 & 9.1 & 0.051 & 84 \\
\hline 88ADw115V46 & 0.19792 & 0.01809 & 0.02802 & 0.00064 & 0.2499 & 178.2 & 4.0 & 164.2 & 199.1 & 178.2 & 4.0 & 0.022 & -9 \\
\hline 88ADw115V48 & 0.20423 & 0.01779 & 0.02877 & 0.00066 & 0.2634 & 182.9 & 4.1 & 192.6 & 188.2 & 182.9 & 4.1 & 0.023 & 5 \\
\hline 88ADW115V72 & 0.06596 & 0.05004 & 0.0307 & 0.00145 & 0.0623 & 195.0 & 9.1 & 0.1 & 0.0 & 195.0 & 9.1 & 0.046 & -194900 \\
\hline $88 A D w 115 V 95$ & 0.22188 & 0.00638 & 0.03233 & 0.00029 & 0.3120 & 205.1 & 1.8 & 209.3 & 63.6 & 205.1 & 1.8 & 0.009 & 2 \\
\hline 88ADw115V25 & 0.27734 & 0.00454 & 0.04054 & 0.00024 & 0.3616 & 256.2 & 1.5 & 266.4 & 35.4 & 256.2 & 1.5 & 0.006 & 4 \\
\hline 88ADW115V80 & 0.32885 & 0.00634 & 0.04539 & 0.00029 & 0.3314 & 286.1 & 4.8 & 338.7 & 40.4 & 286.1 & 4.8 & 0.006 & 16 \\
\hline 88ADw115V21 & 0.38516 & 0.01209 & 0.04988 & 0.00048 & 0.3066 & 313.8 & 2.9 & 303.5 & 65.2 & 313.8 & 2.9 & 0.009 & -3 \\
\hline 88ADw115V12 & 0.38407 & 0.00868 & 0.05228 & 0.00038 & 0.3216 & 328.5 & 2.3 & 313.6 & 46.9 & 328.5 & 2.3 & 0.007 & -5 \\
\hline 88ADW115V69 & 0.15599 & 0.10507 & 0.0531 & 0.00223 & 0.0623 & 333.5 & 13.7 & 0.1 & 0.0 & 333.5 & 13.7 & 0.041 & -333400 \\
\hline 88ADw115V34 & 0.37616 & 0.01869 & 0.05328 & 0.00084 & 0.3173 & 334.7 & 5.2 & 327.0 & 101.4 & 334.7 & 5.2 & 0.015 & -2 \\
\hline 88ADw115V64 & 0.38887 & 0.03664 & 0.05397 & 0.00129 & 0.2537 & 338.9 & 7.9 & 317.5 & 191.4 & 338.9 & 7.9 & 0.023 & -7 \\
\hline 88ADw115V9 & 0.41919 & 0.01401 & 0.05433 & 0.00056 & 0.3084 & 341.1 & 3.4 & 404.8 & 67.0 & 341.1 & 3.4 & 0.010 & 16 \\
\hline 88ADw115V44 & 0.39832 & 0.02219 & 0.05538 & 0.00092 & 0.2982 & 347.5 & 5.7 & 367.2 & 112.1 & 347.5 & 5.7 & 0.016 & 5 \\
\hline 88ADw115V24 & 0.40674 & 0.03012 & 0.05588 & 0.00123 & 0.2972 & 350.5 & 7.5 & 347.6 & 146.4 & 350.5 & 7.5 & 0.021 & -1 \\
\hline 88ADw115V59 & 0.42836 & 0.01331 & 0.05619 & 0.00054 & 0.3093 & 352.4 & 3.3 & 380.9 & 62.6 & 352.4 & 3.3 & 0.009 & 7 \\
\hline 88ADw115V70 & 0.44755 & 0.02053 & 0.06181 & 0.00079 & 0.2786 & 386.6 & 4.8 & 385.0 & 92.0 & 386.6 & 4.8 & 0.012 & 0 \\
\hline 88ADw115V96 & 1.78899 & 0.03449 & 0.08707 & 0.0007 & 0.4170 & 538.2 & 4.1 & 2400.8 & 23.3 & 538.2 & 4.1 & 0.008 & 78 \\
\hline 88ADW115V54 & 3.98693 & 0.04123 & 0.2541 & 0.00089 & 0.3387 & 1459.6 & 4.6 & 1841.3 & 10.3 & 1841.3 & 10.3 & 0.006 & 21 \\
\hline 88ADw115V78 & 4.24177 & 0.09836 & 0.27054 & 0.00184 & 0.2933 & 1543.5 & 9.3 & 1902.6 & 20.9 & 1902.6 & 20.9 & 0.011 & 19 \\
\hline \multicolumn{14}{|c|}{ 88ADw122dz, detrital zircons, $n=67$ of 79 , Univ. of British Columbia } \\
\hline Analysis \# & 207/235 & $\begin{array}{c}1 \sigma \\
\text { error } \\
(\%)\end{array}$ & $206 / 238$ & $\begin{array}{c}1 \sigma \\
\text { error } \\
(\%) \\
\end{array}$ & $\begin{array}{l}\text { Error } \\
\text { cor- } \\
\text { relation }\end{array}$ & $\begin{array}{c}206 / 238 \\
\text { age }\end{array}$ & $\begin{array}{l}1 \sigma \\
\text { error } \\
(\mathrm{Ma})\end{array}$ & $\begin{array}{c}\text { 207/206 } \\
\text { age }\end{array}$ & $\begin{array}{l}1 \sigma \\
\text { error } \\
(\mathrm{Ma})\end{array}$ & $\begin{array}{l}\text { Best } \\
\text { age } \\
(\mathrm{Ma})\end{array}$ & $\begin{array}{l}1 \sigma \\
\text { error } \\
(\mathrm{Ma})\end{array}$ & Error/age & $\begin{array}{c}\text { Dis- } \\
\text { cordance } \\
(\%)\end{array}$ \\
\hline L28 & 0.09192 & 0.00364 & 0.01354 & 0.00017 & 0.3171 & 86.7 & 1.1 & 119.9 & 90.8 & 86.7 & 1.1 & 0.013 & 27.7 \\
\hline L29 & 0.09369 & 0.00221 & 0.01394 & 0.00011 & 0.3345 & 89.2 & 0.7 & 136.1 & 54.5 & 89.2 & 0.7 & 0.008 & 34.5 \\
\hline L22 & 0.09405 & 0.00193 & 0.01415 & 0.0001 & 0.3444 & 90.6 & 0.6 & 94.3 & 48.9 & 90.6 & 0.6 & 0.007 & 3.9 \\
\hline L24 & 0.09693 & 0.00449 & 0.0143 & 0.00021 & 0.3170 & 91.5 & 1.3 & 98.2 & 106.9 & 91.5 & 1.3 & 0.014 & 6.8 \\
\hline L36 & 0.09217 & 0.00316 & 0.01434 & 0.00016 & 0.3254 & 91.8 & 1.0 & 92.7 & 80.4 & 91.8 & 1.0 & 0.011 & 1.0 \\
\hline L14 & 0.09802 & 0.00212 & 0.01436 & 0.00011 & 0.3542 & 91.9 & 0.7 & 95.7 & 51.3 & 91.9 & 0.7 & 0.007 & 4.0 \\
\hline L45 & 0.09677 & 0.0036 & 0.0144 & 0.00016 & 0.2987 & 92.2 & 1.0 & 95.2 & 86.9 & 92.2 & 1.0 & 0.011 & 3.2 \\
\hline L10 & 0.0947 & 0.00591 & 0.01446 & 0.00027 & 0.2992 & 92.5 & 1.7 & 91.2 & 142.1 & 92.5 & 1.7 & 0.019 & -1.4 \\
\hline L27 & 0.09601 & 0.00388 & 0.01449 & 0.00019 & 0.3245 & 92.7 & 1.2 & 97.9 & 93.7 & 92.7 & 1.2 & 0.013 & 5.3 \\
\hline L20 & 0.09553 & 0.00106 & 0.01449 & 0.00006 & 0.3732 & 92.7 & 0.4 & 101.3 & 26.0 & 92.7 & 0.4 & 0.004 & 8.5 \\
\hline L46 & 0.098 & 0.00284 & 0.01449 & 0.00014 & 0.3334 & 92.8 & 0.9 & 86.8 & 68.1 & 92.8 & 0.9 & 0.009 & -6.9 \\
\hline L33 & 0.09254 & 0.00398 & 0.01452 & 0.00021 & 0.3363 & 92.9 & 1.3 & 101.2 & 98.7 & 92.9 & 1.3 & 0.014 & 8.2 \\
\hline L16 & 0.0979 & 0.00227 & 0.01454 & 0.00012 & 0.3559 & 93.0 & 0.7 & 95.1 & 54.9 & 93.0 & 0.7 & 0.008 & 2.2 \\
\hline L8 & 0.10137 & 0.00422 & 0.01455 & 0.0002 & 0.3302 & 93.1 & 1.3 & 100.9 & 94.5 & 93.1 & 1.3 & 0.014 & 7.7 \\
\hline L15 & 0.09687 & 0.00525 & 0.01456 & 0.00024 & 0.3041 & 93.2 & 1.6 & 95.4 & 124.0 & 93.2 & 1.6 & 0.017 & 2.3 \\
\hline L21 & 0.09543 & 0.00293 & 0.01457 & 0.00015 & 0.3353 & 93.2 & 1.0 & 98.9 & 72.0 & 93.2 & 1.0 & 0.010 & 5.8 \\
\hline L18 & 0.09714 & 0.00254 & 0.01461 & 0.00011 & 0.2879 & 93.5 & 0.7 & 95.0 & 61.8 & 93.5 & 0.7 & 0.008 & 1.6 \\
\hline L23 & 0.0967 & 0.00432 & 0.01461 & 0.00022 & 0.3371 & 93.5 & 1.4 & 95.3 & 103.2 & 93.5 & 1.4 & 0.015 & 1.9 \\
\hline L37 & 0.09698 & 0.00281 & 0.01461 & 0.00013 & 0.3071 & 93.5 & 0.9 & 101.7 & 67.0 & 93.5 & 0.9 & 0.009 & 8.1 \\
\hline
\end{tabular}


Table 2. U-Pb analytical data for detrital and igneous zircons, identified by sample number and lab.-Continued

\begin{tabular}{|c|c|c|c|c|c|c|c|c|c|c|c|c|c|}
\hline L11 & 0.10092 & 0.00478 & 0.01463 & 0.00021 & 0.3031 & 93.6 & 1.3 & 94.6 & 108.9 & 93.6 & 1.3 & 0.014 & 1.1 \\
\hline L9 & 0.09817 & 0.00238 & 0.01466 & 0.00012 & 0.3376 & 93.8 & 0.8 & 93.2 & 57.0 & 93.8 & 0.8 & 0.008 & -0.6 \\
\hline L31 & 0.09783 & 0.00254 & 0.01472 & 0.00013 & 0.3402 & 94.2 & 0.8 & 95.9 & 61.3 & 94.2 & 0.8 & 0.008 & 1.8 \\
\hline L7 & 0.09585 & 0.00484 & 0.01475 & 0.00024 & 0.3222 & 94.4 & 1.6 & 94.2 & 115.8 & 94.4 & 1.6 & 0.016 & -0.2 \\
\hline L53 & 0.09919 & 0.00411 & 0.01477 & 0.00019 & 0.3105 & 94.5 & 1.2 & 101.3 & 95.1 & 94.5 & 1.2 & 0.013 & 6.7 \\
\hline L52 & 0.09723 & 0.0032 & 0.01481 & 0.00016 & 0.3283 & 94.8 & 1.0 & 93.1 & 77.1 & 94.8 & 1.0 & 0.011 & -1.8 \\
\hline L55 & 0.09854 & 0.00393 & 0.01484 & 0.00019 & 0.3210 & 95.0 & 1.2 & 90.7 & 92.8 & 95.0 & 1.2 & 0.013 & -4.7 \\
\hline L12 & 0.10154 & 0.00359 & 0.01488 & 0.00018 & 0.3421 & 95.2 & 1.1 & 98.3 & 82.0 & 95.2 & 1.1 & 0.012 & 3.2 \\
\hline L60 & 0.09785 & 0.00349 & 0.01487 & 0.00017 & 0.3205 & 95.2 & 1.1 & 100.4 & 82.4 & 95.2 & 1.1 & 0.011 & 5.2 \\
\hline L6 & 0.09659 & 0.00394 & 0.0149 & 0.00021 & 0.3455 & 95.4 & 1.3 & 94.3 & 94.2 & 95.4 & 1.3 & 0.014 & -1.2 \\
\hline L43 & 0.10165 & 0.00559 & 0.0149 & 0.00023 & 0.2807 & 95.4 & 1.5 & 97.2 & 126.3 & 95.4 & 1.5 & 0.015 & 1.9 \\
\hline L44 & 0.10114 & 0.00275 & 0.01494 & 0.00013 & 0.3200 & 95.6 & 0.8 & 103.1 & 62.9 & 95.6 & 0.8 & 0.009 & 7.3 \\
\hline Ł39 & 0.10381 & 0.00301 & 0.01496 & 0.00013 & 0.2997 & 95.7 & 0.8 & 228.0 & 65.5 & 95.7 & 0.8 & 0.009 & 58.0 \\
\hline L49 & 0.09793 & 0.00303 & 0.01497 & 0.00016 & 0.3454 & 95.8 & 1.0 & 103.8 & 71.5 & 95.8 & 1.0 & 0.010 & 7.7 \\
\hline$\llcorner 61$ & 0.099887 & 0.00372 & 0.01497 & 0.00019 & 0.3407 & 25.8 & 1.2 & 110.8 & 85.7 & 25.8 & 1.2 & 0.012 & 13.5 \\
\hline L62 & 0.09795 & 0.00409 & 0.01507 & 0.0002 & 0.3178 & 96.5 & 1.3 & 97.1 & 97.3 & 96.5 & 1.3 & 0.013 & 0.6 \\
\hline L47 & 0.10153 & 0.00198 & 0.01511 & 0.0001 & 0.3394 & 96.7 & 0.6 & 103.4 & 45.2 & 96.7 & 0.6 & 0.007 & 6.5 \\
\hline L40 & 0.09978 & 0.00498 & 0.01511 & 0.00022 & 0.2917 & 96.7 & 1.4 & 104.2 & 113.8 & 96.7 & 1.4 & 0.014 & 7.2 \\
\hline L5 & 0.09996 & 0.00469 & 0.01517 & 0.00022 & 0.3091 & 97.1 & 1.4 & 96.3 & 107.9 & 97.1 & 1.4 & 0.014 & -0.8 \\
\hline L72 & 0.09911 & 0.0101 & 0.01524 & 0.00042 & 0.2704 & 97.5 & 2.7 & 101.2 & 225.5 & 97.5 & 2.7 & 0.027 & 3.7 \\
\hline L48 & 0.10053 & 0.00222 & 0.01528 & 0.00012 & 0.3556 & 97.8 & 0.7 & 98.6 & 52.4 & 97.8 & 0.7 & 0.007 & 0.8 \\
\hline L58 & 0.10295 & 0.00254 & 0.01528 & 0.00013 & 0.3448 & 97.8 & 0.8 & 103.1 & 57.1 & 97.8 & 0.8 & 0.008 & 5.1 \\
\hline L2 & 0.1033 & 0.00383 & 0.01531 & 0.00018 & 0.3171 & 98.0 & 1.2 & 102.3 & 84.3 & 98.0 & 1.2 & 0.012 & 4.2 \\
\hline$\llcorner 57$ & 0.10462 & 0.00494 & 0.01532 & 0.00021 & 0.2903 & 98.0 & 1.3 & 234.6 & 105.5 & 98.0 & 1.3 & 0.014 & 58.2 \\
\hline L68 & 0.11056 & 0.00389 & 0.01536 & 0.00018 & 0.3331 & 98.3 & 1.1 & 342.7 & 77.7 & 98.3 & 1.1 & 0.011 & 71.3 \\
\hline L41 & 0.10022 & 0.0031 & 0.01538 & 0.00014 & 0.2943 & 98.4 & 0.9 & 101.3 & 71.4 & 98.4 & 0.9 & 0.009 & 2.9 \\
\hline L1 & 0.10217 & 0.00284 & 0.01543 & 0.00014 & 0.3264 & 98.7 & 0.9 & 105.2 & 63.8 & 98.7 & 0.9 & 0.009 & 6.2 \\
\hline L70 & 0.10116 & 0.00313 & 0.01548 & 0.00015 & 0.3132 & 99.0 & 1.0 & 94.1 & 72.7 & 99.0 & 1.0 & 0.010 & -5.2 \\
\hline L56 & 0.10137 & 0.00553 & 0.01551 & 0.00027 & 0.3191 & 99.2 & 1.7 & 103.5 & 124.0 & 99.2 & 1.7 & 0.017 & 4.2 \\
\hline L69 & 0.11502 & 0.00444 & 0.01569 & 0.0002 & 0.3302 & 100.3 & 1.3 & 284.5 & 85.6 & 100.3 & 1.3 & 0.013 & 64.7 \\
\hline L17 & 0.10867 & 0.00526 & 0.01573 & 0.00024 & 0.3152 & 100.6 & 1.5 & 105.6 & 109.4 & 100.6 & 1.5 & 0.015 & 4.7 \\
\hline L82 & 0.10879 & 0.0044 & 0.01576 & 0.0002 & 0.3138 & 100.8 & 1.3 & 106.4 & 92.7 & 100.8 & 1.3 & 0.013 & 5.3 \\
\hline L80 & 0.10295 & 0.0052 & 0.01589 & 0.00025 & 0.3115 & 101.6 & 1.6 & 101.8 & 115.5 & 101.6 & 1.6 & 0.016 & 0.2 \\
\hline L75 & 0.10987 & 0.00921 & 0.01589 & 0.00044 & 0.3303 & 101.7 & 2.8 & 97.6 & 188.2 & 101.7 & 2.8 & 0.027 & -4.2 \\
\hline$\llcorner 67$ & 0.11031 & 0.00229 & 0.01595 & 0.00012 & 0.3624 & 102.0 & 0.8 & 235.0 & 47.0 & 102.0 & 0.8 & 0.008 & 56.6 \\
\hline L79 & 0.10685 & 0.00382 & 0.01597 & 0.00019 & 0.3328 & 102.1 & 1.2 & 108.2 & 82.2 & 102.1 & 1.2 & 0.012 & 5.6 \\
\hline L66 & 0.10643 & 0.00425 & 0.01597 & 0.00021 & 0.3293 & 102.1 & 1.3 & 111.2 & 91.6 & 102.1 & 1.3 & 0.013 & 8.2 \\
\hline L64 & 0.10713 & 0.00579 & 0.01604 & 0.00027 & 0.3115 & 102.6 & 1.7 & 108.6 & 122.7 & 102.6 & 1.7 & 0.017 & 5.5 \\
\hline L81 & 0.1052 & 0.00942 & 0.01607 & 0.00039 & 0.2710 & 102.8 & 2.5 & 102.8 & 199.6 & 102.8 & 2.5 & 0.024 & 0.0 \\
\hline 583 & 0.10985 & 0.00608 & 0.01608 & 0.0003 & 0.3371 & 102.8 & 1.9 & 244.8 & 122.9 & 102.8 & 1.9 & 0.018 & 58.0 \\
\hline L63 & 0.11238 & 0.00672 & 0.0162 & 0.0003 & 0.3097 & 103.6 & 1.9 & 106.8 & 135.0 & 103.6 & 1.9 & 0.018 & 3.0 \\
\hline L76 & 0.10705 & 0.00359 & 0.01622 & 0.00019 & 0.3493 & 103.7 & 1.2 & 108.7 & 77.1 & 103.7 & 1.2 & 0.011 & 4.6 \\
\hline L71 & 0.10743 & 0.00339 & 0.01623 & 0.00017 & 0.3319 & 103.8 & 1.1 & 107.3 & 72.7 & 103.8 & 1.1 & 0.011 & 3.3 \\
\hline L78 & 0.1088 & 0.00532 & 0.01629 & 0.00024 & 0.3013 & 104.2 & 1.5 & 107.8 & 111.6 & 104.2 & 1.5 & 0.014 & 3.3 \\
\hline L73 & 0.11188 & 0.00428 & 0.01635 & 0.00021 & 0.3357 & 104.5 & 1.4 & 105.4 & 87.7 & 104.5 & 1.4 & 0.013 & 0.9 \\
\hline L4 & 0.10949 & 0.004 & 0.0165 & 0.00019 & 0.3152 & 105.5 & 1.2 & 110.0 & 82.7 & 105.5 & 1.2 & 0.012 & 4.1 \\
\hline$\llcorner 77$ & 0.10847 & 0.00464 & 0.0165 & 0.00023 & 0.3259 & 105.5 & 1.5 & 164.4 & 97.0 & 105.5 & 1.5 & 0.014 & 35.8 \\
\hline L74 & 0.10595 & 0.00626 & 0.01651 & 0.00033 & 0.3383 & 105.6 & 2.1 & 113.3 & 133.8 & 105.6 & 2.1 & 0.020 & 6.8 \\
\hline L35 & 0.14289 & 0.0084 & 0.02112 & 0.00037 & 0.2980 & 134.7 & 2.3 & 145.9 & 129.8 & 134.7 & 2.3 & 0.017 & 7.7 \\
\hline L30 & 0.15558 & 0.00359 & 0.02275 & 0.00017 & 0.3238 & 145.0 & 1.0 & 147.2 & 51.7 & 145.0 & 1.0 & 0.007 & 1.5 \\
\hline L32 & 0.16167 & 0.00555 & 0.0232 & 0.00026 & 0.3265 & 147.8 & 1.6 & 157.2 & 75.6 & 147.8 & 1.6 & 0.011 & 6.0 \\
\hline L50 & 0.16987 & 0.00467 & 0.02436 & 0.00022 & 0.3285 & 155.2 & 1.4 & 163.7 & 60.8 & 155.2 & 1.4 & 0.009 & 5.2 \\
\hline L59 & 0.16739 & 0.00741 & 0.02501 & 0.00033 & 0.2981 & 159.3 & 2.1 & 169.2 & 97.8 & 159.3 & 2.1 & 0.013 & 5.9 \\
\hline L54 & 0.17499 & 0.00781 & 0.02582 & 0.00033 & 0.2864 & 164.3 & 2.1 & 176.7 & 98.5 & 164.3 & 2.1 & 0.012 & 7.0 \\
\hline$\llcorner 19$ & 0.47449 & 0.01416 & 0.02626 & 0.00037 & 0.4721 & 167.1 & 2.3 & 2184.2 & 46.5 & 167.1 & 2.3 & 0.014 & 92.3 \\
\hline L34 & 0.19265 & 0.00784 & 0.02748 & 0.00034 & 0.3040 & 174.8 & 2.1 & 176.4 & 88.2 & 174.8 & 2.1 & 0.012 & 0.9 \\
\hline L13 & 0.18833 & 0.0024 & 0.0275 & 0.00013 & 0.3710 & 174.9 & 0.8 & 174.2 & 27.8 & 174.9 & 0.8 & 0.005 & -0.4 \\
\hline L42 & 0.19707 & 0.01089 & 0.02855 & 0.00047 & 0.2979 & 181.5 & 2.9 & 188.1 & 118.6 & 181.5 & 2.9 & 0.016 & 3.5 \\
\hline 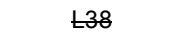 & 0.39477 & 0.01331 & 0.02963 & 0.00039 & 0.3904 & 188.2 & 2.4 & 1550.2 & 57.3 & 188.2 & 2.4 & 0.013 & 87.9 \\
\hline L65 & 0.20568 & 0.00267 & 0.03002 & 0.00015 & 0.3849 & 190.7 & 0.9 & 192.1 & 28.0 & 190.7 & 0.9 & 0.005 & 0.7 \\
\hline \multicolumn{14}{|c|}{ 04ADw600a, detrital zircons, $n=24$, Univ. of Bristish Columbia } \\
\hline Analysis \# & $207 / 235$ & $\begin{array}{c}1 \sigma \\
\text { error } \\
(\%)\end{array}$ & $206 / 238$ & $\begin{array}{c}1 \sigma \\
\text { error } \\
(\%)\end{array}$ & $\begin{array}{l}\text { Error } \\
\text { cor- } \\
\text { relation }\end{array}$ & $\begin{array}{c}206 / 238 \\
\text { age }\end{array}$ & $\begin{array}{c}1 \sigma \\
\text { error } \\
(\mathrm{Ma})\end{array}$ & $\begin{array}{l}207 / 206 \\
\text { age }\end{array}$ & $\begin{array}{l}1 \sigma \\
\text { error } \\
(\mathrm{Ma})\end{array}$ & $\begin{array}{l}\text { Best } \\
\text { age } \\
(\mathrm{Ma})\end{array}$ & $\begin{array}{c}1 \sigma \\
\text { error } \\
(\mathrm{Ma})\end{array}$ & Error/age & $\begin{array}{c}\text { Dis- } \\
\text { cordance } \\
(\%)\end{array}$ \\
\hline 04ADW600A13 & 0.24198 & 0.04575 & 0.02127 & 0.00101 & 0.2512 & 135.7 & 6.4 & 1225.9 & 335.7 & 135.7 & 6.4 & 0.047 & \\
\hline 04ADW600A19 & 0.15821 & 0.0222 & 0.02208 & 0.00058 & 0.1872 & 140.8 & 3.6 & 380.0 & 288.4 & 140.8 & 3.6 & 0.026 & \\
\hline 04ADW600A23 & 0.17383 & 0.04017 & 0.02234 & 0.0009 & 0.1743 & 142.4 & 5.7 & 480.0 & 444.1 & 142.4 & 5.7 & 0.040 & \\
\hline 04ADW600A2 & 0.10438 & 0.0259 & 0.02303 & 0.00065 & 0.1137 & 146.8 & 4.1 & 0.1 & 0.0 & 146.8 & 4.1 & 0.028 & \\
\hline 04ADW600A15 & 0.16808 & 0.02797 & 0.02309 & 0.00066 & 0.1718 & 147.2 & 4.2 & 276.6 & 342.4 & 147.2 & 4.2 & 0.028 & \\
\hline 04ADW600A12 & 0.14242 & 0.03303 & 0.0232 & 0.00074 & 0.1375 & 147.9 & 4.7 & 0.1 & 433.2 & 147.9 & 4.7 & 0.032 & \\
\hline
\end{tabular}


Table 2. U-Pb analytical data for detrital and igneous zircons, identified by sample number and lab.-Continued

\begin{tabular}{|c|c|c|c|c|c|c|c|c|c|c|c|}
\hline 04ADW600A1 & 0.15508 & 0.00814 & 0.0233 & 0.00026 & 0.2126 & 148.5 & 1.7 & 102.5 & 119.4 & 148.5 & 1.7 \\
\hline 04ADW600A10 & 0.14181 & 0.02089 & 0.02333 & 0.00054 & 0.1571 & 148.6 & 3.4 & 0.1 & 204.7 & 148.6 & 3.4 \\
\hline 04ADW600A22 & 0.16148 & 0.00867 & 0.02347 & 0.00034 & 0.2698 & 149.6 & 2.1 & 240.1 & 116.8 & 149.6 & 2.1 \\
\hline 04ADW600A7 & 0.12154 & 0.02699 & 0.02368 & 0.00068 & 0.1293 & 150.9 & 4.3 & 0.1 & 0.0 & 150.9 & 4.3 \\
\hline 04ADW600A6 & 0.15166 & 0.01752 & 0.02377 & 0.00049 & 0.1784 & 151.4 & 3.1 & 44.6 & 255.7 & 151.4 & 3.1 \\
\hline 04ADW600A18 & 0.15515 & 0.00705 & 0.02388 & 0.00026 & 0.2396 & 152.1 & 1.7 & 4.2 & 103.6 & 152.1 & 1.7 \\
\hline 04ADW600A20 & 0.11689 & 0.03398 & 0.02391 & 0.00072 & 0.1036 & 152.3 & 4.5 & 0.1 & 0.0 & 152.3 & 4.5 \\
\hline 04ADW600A3 & 0.15589 & 0.00946 & 0.02398 & 0.00031 & 0.2130 & 152.8 & 1.9 & 35.5 & 139.2 & 152.8 & 1.9 \\
\hline 04ADW600A17 & 0.24599 & 0.02939 & 0.02415 & 0.00066 & 0.2287 & 153.8 & 4.2 & 1018.6 & 223.9 & 153.8 & 4.2 \\
\hline 04ADW600A4 & 0.15447 & 0.01086 & 0.02424 & 0.00035 & 0.2054 & 154.4 & 2.2 & 71.8 & 159.6 & 154.4 & 2.2 \\
\hline 04ADW600A8 & 0.16892 & 0.02324 & 0.02437 & 0.00063 & 0.1879 & 155.2 & 4.0 & 314.6 & 286.7 & 155.2 & 4.0 \\
\hline 04ADW600A5 & 0.09203 & 0.06063 & 0.02441 & 0.00117 & 0.0728 & 155.4 & 7.4 & 0.1 & 0.0 & 155.4 & 7.4 \\
\hline 04ADW600A14 & 0.16141 & 0.01142 & 0.02439 & 0.00038 & 0.2202 & 155.4 & 2.4 & 111.8 & 157.8 & 155.4 & 2.4 \\
\hline 04ADW600A21 & 0.16679 & 0.02254 & 0.02441 & 0.00058 & 0.1758 & 155.5 & 3.6 & 133.7 & 289.0 & 155.5 & 3.6 \\
\hline 04ADW600A11 & 0.11587 & 0.02384 & 0.02486 & 0.00056 & 0.1095 & 158.3 & 3.5 & 0.1 & 0.0 & 158.3 & 3.5 \\
\hline 04ADW600A16 & 0.20379 & 0.05176 & 0.02489 & 0.00113 & 0.1787 & 158.5 & 7.1 & 553.9 & 476.4 & 158.5 & 7.1 \\
\hline 04ADW600A9 & 0.16652 & 0.02538 & 0.02496 & 0.00066 & 0.1735 & 158.9 & 4.1 & 159.6 & 321.9 & 158.9 & 4.1 \\
\hline 04ADW600A24 & 0.17675 & 0.01604 & 0.02513 & 0.00051 & 0.2236 & 160.0 & 3.2 & 222.0 & 195.1 & 160.0 & 3.2 \\
\hline
\end{tabular}

\begin{tabular}{|c|c|c|c|c|c|c|c|c|c|c|c|c|}
\hline $84905-100$ & 0.0855 & 0.0251 & 0.0130 & 0.0011 & 83.6 & 7.0 & 75.9 & 23.1 & 83.6 & 7.0 & 0.152 & $10.07 \%$ \\
\hline $84905-65$ & 0.0902 & 0.0179 & 0.0137 & 0.0006 & 87.5 & 4.1 & 94.4 & 19.1 & 87.5 & 4.1 & 0.101 & $7.34 \%$ \\
\hline $84905-72$ & 0.0907 & 0.0083 & 0.0137 & 0.0004 & 87.9 & 2.8 & 93.4 & 8.9 & 87.9 & 2.8 & 0.047 & $5.86 \%$ \\
\hline $84905-55$ & 0.0922 & 0.0152 & 0.0140 & 0.0006 & 89.3 & 3.6 & 95.7 & 16.1 & 89.3 & 3.6 & 0.084 & $6.65 \%$ \\
\hline 84905-39 & 0.0929 & 0.0113 & 0.0141 & 0.0005 & 90.0 & 3.5 & 94.4 & 11.8 & 90.0 & 3.5 & 0.063 & $4.62 \%$ \\
\hline $84905-5$ & 0.0944 & 0.0112 & 0.0143 & 0.0004 & 91.4 & 2.4 & 94.8 & 11.5 & 91.4 & 2.4 & 0.060 & $3.64 \%$ \\
\hline 84905-3 & 0.0963 & 0.0111 & 0.0146 & 0.0005 & 93.2 & 3.2 & 97.8 & 11.7 & 93.2 & 3.2 & 0.060 & $4.76 \%$ \\
\hline $84905-18$ & 0.0966 & 0.0169 & 0.0146 & 0.0007 & 93.3 & 4.8 & 101.5 & 18.4 & 93.3 & 4.8 & 0.090 & $8.01 \%$ \\
\hline $84905-36$ & 0.0966 & 0.0150 & 0.0146 & 0.0007 & 93.4 & 4.5 & 100.7 & 16.2 & 93.4 & 4.5 & 0.080 & $7.26 \%$ \\
\hline $84905-54$ & 0.0968 & 0.0155 & 0.0146 & 0.0005 & 93.6 & 3.4 & 98.4 & 16.0 & 93.6 & 3.4 & 0.081 & $4.90 \%$ \\
\hline $84905-47$ & 0.0967 & 0.0202 & 0.0147 & 0.0008 & 93.8 & 5.0 & 92.0 & 19.7 & 93.8 & 5.0 & 0.107 & $-1.96 \%$ \\
\hline $84905-7$ & 0.0974 & 0.0101 & 0.0147 & 0.0005 & 94.1 & 3.1 & 97.5 & 10.3 & 94.1 & 3.1 & 0.053 & $3.47 \%$ \\
\hline $84905-80$ & 0.0991 & 0.0084 & 0.0150 & 0.0004 & 95.8 & 2.3 & 97.4 & 8.5 & 95.8 & 2.3 & 0.044 & $1.56 \%$ \\
\hline $84905-14$ & 0.0994 & 0.0136 & 0.0150 & 0.0008 & 95.9 & 5.2 & 106.0 & 15.2 & 95.9 & 5.2 & 0.072 & $9.54 \%$ \\
\hline $84905-84$ & 0.1001 & 0.0090 & 0.0151 & 0.0005 & 96.7 & 2.9 & 101.4 & 9.4 & 96.7 & 2.9 & 0.046 & $4.66 \%$ \\
\hline $84905-62$ & 0.1001 & 0.0081 & 0.0151 & 0.0004 & 96.7 & 2.2 & 99.5 & 8.3 & 96.7 & 2.2 & 0.042 & $2.80 \%$ \\
\hline $84905-9$ & 0.1002 & 0.0132 & 0.0151 & 0.0004 & 96.9 & 2.9 & 100.0 & 13.3 & 96.9 & 2.9 & 0.067 & $3.08 \%$ \\
\hline $84905-96$ & 0.1003 & 0.0061 & 0.0151 & 0.0003 & 96.9 & 2.0 & 99.2 & 6.2 & 96.9 & 2.0 & 0.031 & $2.32 \%$ \\
\hline $84905-13$ & 0.1004 & 0.0068 & 0.0152 & 0.0003 & 97.0 & 2.0 & 99.8 & 6.9 & 97.0 & 2.0 & 0.035 & $2.85 \%$ \\
\hline $84905-56$ & 0.1008 & 0.0135 & 0.0152 & 0.0008 & 97.2 & 4.9 & 105.9 & 14.9 & 97.2 & 4.9 & 0.070 & $8.22 \%$ \\
\hline $84905-73$ & 0.1011 & 0.0234 & 0.0152 & 0.0009 & 97.4 & 5.6 & 107.4 & 25.5 & 97.4 & 5.6 & 0.119 & $9.27 \%$ \\
\hline $84905-16$ & 0.1011 & 0.0101 & 0.0153 & 0.0005 & 97.6 & 3.0 & 103.2 & 10.6 & 97.6 & 3.0 & 0.051 & $5.39 \%$ \\
\hline $84905-63$ & 0.1013 & 0.0182 & 0.0153 & 0.0007 & 97.7 & 4.3 & 103.3 & 18.9 & 97.7 & 4.3 & 0.091 & $5.39 \%$ \\
\hline $84905-78$ & 0.1013 & 0.0058 & 0.0153 & 0.0003 & 97.8 & 1.9 & 100.8 & 6.0 & 97.8 & 1.9 & 0.030 & $2.95 \%$ \\
\hline $84905-23$ & 0.1016 & 0.0134 & 0.0153 & 0.0005 & 98.0 & 3.1 & 101.0 & 13.6 & 98.0 & 3.1 & 0.067 & $2.97 \%$ \\
\hline $84905-24$ & 0.1019 & 0.0131 & 0.0154 & 0.0005 & 98.3 & 3.1 & 101.9 & 13.4 & 98.3 & 3.1 & 0.066 & $3.59 \%$ \\
\hline $84905-20$ & 0.1037 & 0.0155 & 0.0156 & 0.0006 & 99.9 & 4.2 & 107.4 & 16.5 & 99.9 & 4.2 & 0.077 & $7.00 \%$ \\
\hline $84905-64$ & 0.1034 & 0.0077 & 0.0156 & 0.0003 & 100.0 & 1.9 & 96.2 & 7.3 & 100.0 & 1.9 & 0.038 & $-3.94 \%$ \\
\hline $84905-45$ & 0.1038 & 0.0220 & 0.0156 & 0.0008 & 100.0 & 5.0 & 104.7 & 22.6 & 100.0 & 5.0 & 0.108 & $4.44 \%$ \\
\hline $84905-58$ & 0.1039 & 0.0083 & 0.0157 & 0.0004 & 100.2 & 2.8 & 104.5 & 8.7 & 100.2 & 2.8 & 0.042 & $4.07 \%$ \\
\hline $84905-83$ & 0.1042 & 0.0094 & 0.0157 & 0.0003 & 100.4 & 2.1 & 102.8 & 9.5 & 100.4 & 2.1 & 0.046 & $2.26 \%$ \\
\hline $84905-50$ & 0.1043 & 0.0089 & 0.0157 & 0.0004 & 100.5 & 2.8 & 105.9 & 9.4 & 100.5 & 2.8 & 0.044 & $5.08 \%$ \\
\hline $84905-69$ & 0.1045 & 0.0104 & 0.0157 & 0.0005 & 100.7 & 3.1 & 105.0 & 10.7 & 100.7 & 3.1 & 0.051 & $4.08 \%$ \\
\hline
\end{tabular}


Table 2. U-Pb analytical data for detrital and igneous zircons, identified by sample number and lab.-Continued

\begin{tabular}{|c|c|c|c|c|c|c|c|c|c|c|c|c|}
\hline $84905-67$ & 0.1049 & 0.0104 & 0.0158 & 0.0004 & 101.1 & 2.8 & 104.6 & 10.7 & 101.1 & 2.8 & 0.051 & $3.33 \%$ \\
\hline $84905-93$ & 0.1051 & 0.0277 & 0.0158 & 0.0005 & 101.2 & 3.2 & 104.9 & 27.8 & 101.2 & 3.2 & 0.132 & $3.53 \%$ \\
\hline $84905-1$ & 0.1050 & 0.0090 & 0.0158 & 0.0004 & 101.3 & 2.2 & 104.5 & 9.2 & 101.3 & 2.2 & 0.044 & $3.09 \%$ \\
\hline $84905-79$ & 0.1052 & 0.0079 & 0.0159 & 0.0004 & 101.4 & 2.8 & 107.0 & 8.3 & 101.4 & 2.8 & 0.039 & $5.23 \%$ \\
\hline $84905-10$ & 0.1052 & 0.0121 & 0.0159 & 0.0005 & 101.4 & 3.2 & 106.5 & 12.6 & 101.4 & 3.2 & 0.059 & $4.82 \%$ \\
\hline $84905-25$ & 0.1060 & 0.0131 & 0.0159 & 0.0006 & 102.0 & 4.0 & 109.9 & 14.0 & 102.0 & 4.0 & 0.064 & $7.25 \%$ \\
\hline $84905-57$ & 0.1066 & 0.0091 & 0.0161 & 0.0005 & 102.7 & 2.9 & 105.9 & 9.3 & 102.7 & 2.9 & 0.044 & $3.00 \%$ \\
\hline $84905-74$ & 0.1072 & 0.0113 & 0.0161 & 0.0004 & 103.3 & 2.4 & 105.3 & 11.3 & 103.3 & 2.4 & 0.054 & $1.92 \%$ \\
\hline $84905-99$ & 0.1083 & 0.0285 & 0.0163 & 0.0005 & 104.2 & 3.3 & 110.0 & 29.1 & 104.2 & 3.3 & 0.132 & $5.33 \%$ \\
\hline $84905-81$ & 0.1091 & 0.0082 & 0.0164 & 0.0004 & 104.9 & 2.3 & 109.0 & 8.4 & 104.9 & 2.3 & 0.039 & $3.78 \%$ \\
\hline $84905-68$ & 0.1095 & 0.0121 & 0.0165 & 0.0006 & 105.3 & 3.6 & 110.0 & 12.5 & 105.3 & 3.6 & 0.057 & $4.28 \%$ \\
\hline $84905-70$ & 0.1098 & 0.0142 & 0.0165 & 0.0005 & 105.7 & 3.3 & 108.2 & 14.2 & 105.7 & 3.3 & 0.066 & $2.28 \%$ \\
\hline $84905-91$ & 0.1096 & 0.0076 & 0.0165 & 0.0004 & 105.7 & 2.4 & 101.7 & 7.2 & 105.7 & 2.4 & 0.035 & $-3.98 \%$ \\
\hline $84905-90$ & 0.1114 & 0.0109 & 0.0167 & 0.0004 & 107.0 & 2.8 & 111.4 & 11.1 & 107.0 & 2.8 & 0.050 & $3.98 \%$ \\
\hline $84905-89$ & 0.1115 & 0.0169 & 0.0167 & 0.0007 & 107.1 & 4.3 & 113.5 & 17.7 & 107.1 & 4.3 & 0.078 & $5.68 \%$ \\
\hline $84905-2$ & 0.1145 & 0.0243 & 0.0172 & 0.0008 & 109.7 & 5.2 & 118.5 & 25.5 & 109.7 & 5.2 & 0.108 & $7.46 \%$ \\
\hline $84905-43$ & 0.1146 & 0.0219 & 0.0172 & 0.0009 & 110.2 & 6.0 & 110.6 & 21.8 & 110.2 & 6.0 & 0.098 & $0.42 \%$ \\
\hline $84905-44$ & 0.1187 & 0.0125 & 0.0178 & 0.0006 & 113.6 & 3.7 & 118.6 & 13.0 & 113.6 & 3.7 & 0.055 & $4.18 \%$ \\
\hline $84905-41$ & 0.1199 & 0.0243 & 0.0179 & 0.0015 & 114.1 & 9.8 & 131.8 & 28.3 & 114.1 & 9.8 & 0.107 & $13.39 \%$ \\
\hline $84905-37$ & 0.1337 & 0.0211 & 0.0199 & 0.0008 & 126.9 & 5.3 & 137.0 & 22.3 & 126.9 & 5.3 & 0.081 & $7.41 \%$ \\
\hline $84905-34$ & 0.1337 & 0.0155 & 0.0200 & 0.0007 & 127.5 & 4.3 & 126.0 & 15.1 & 127.5 & 4.3 & 0.060 & $-1.14 \%$ \\
\hline $84905-22$ & 0.1363 & 0.0348 & 0.0204 & 0.0014 & 130.2 & 8.9 & 120.0 & 31.4 & 130.2 & 8.9 & 0.131 & $-8.47 \%$ \\
\hline $84905-26$ & 0.1363 & 0.0348 & 0.0204 & 0.0014 & 130.2 & 8.9 & 120.0 & 31.4 & 130.2 & 8.9 & 0.131 & $-8.47 \%$ \\
\hline $84905-86$ & 0.1444 & 0.0028 & 0.0214 & 0.0003 & 136.6 & 1.9 & 140.1 & 2.6 & 136.6 & 1.9 & 0.009 & $2.47 \%$ \\
\hline $84905-87$ & 0.1454 & 0.0030 & 0.0216 & 0.0003 & 137.5 & 2.0 & 141.3 & 2.8 & 137.5 & 2.0 & 0.010 & $2.70 \%$ \\
\hline $84905-30$ & 0.1523 & 0.0128 & 0.0225 & 0.0006 & 143.5 & 3.7 & 150.5 & 13.1 & 143.5 & 3.7 & 0.044 & $4.65 \%$ \\
\hline $84905-32$ & 0.1536 & 0.0153 & 0.0227 & 0.0007 & 144.8 & 4.3 & 150.5 & 15.5 & 144.8 & 4.3 & 0.051 & $3.77 \%$ \\
\hline $84905-28$ & 0.1548 & 0.0185 & 0.0229 & 0.0006 & 145.7 & 4.1 & 151.5 & 18.4 & 145.7 & 4.1 & 0.061 & $3.87 \%$ \\
\hline $84905-29$ & 0.1590 & 0.0146 & 0.0234 & 0.0006 & 149.4 & 3.9 & 156.2 & 14.8 & 149.4 & 3.9 & 0.047 & $4.33 \%$ \\
\hline $84905-40$ & 0.1615 & 0.0070 & 0.0238 & 0.0005 & 151.7 & 3.3 & 156.7 & 7.1 & 151.7 & 3.3 & 0.023 & $3.21 \%$ \\
\hline $84905-38$ & 0.1620 & 0.0192 & 0.0238 & 0.0010 & 151.8 & 6.1 & 162.1 & 19.9 & 151.8 & 6.1 & 0.061 & $6.38 \%$ \\
\hline $84905-4$ & 0.1625 & 0.0076 & 0.0239 & 0.0004 & 152.5 & 2.7 & 157.1 & 7.5 & 152.5 & 2.7 & 0.024 & $2.93 \%$ \\
\hline $84905-42$ & 0.1655 & 0.0096 & 0.0244 & 0.0006 & 155.1 & 4.1 & 162.1 & 9.6 & 155.1 & 4.1 & 0.030 & $4.33 \%$ \\
\hline $84905-6$ & 0.1658 & 0.0174 & 0.0244 & 0.0007 & 155.3 & 4.3 & 163.0 & 17.6 & 155.3 & 4.3 & 0.054 & $4.78 \%$ \\
\hline $84905-60$ & 0.1670 & 0.0176 & 0.0245 & 0.0006 & 156.3 & 4.1 & 162.8 & 17.5 & 156.3 & 4.1 & 0.054 & $3.99 \%$ \\
\hline $84905-17$ & 0.2080 & 0.0170 & 0.0301 & 0.0008 & 191.1 & 5.1 & 200.7 & 17.0 & 191.1 & 5.1 & 0.042 & $4.78 \%$ \\
\hline $84905-66$ & 0.2224 & 0.0119 & 0.0320 & 0.0009 & 203.1 & 5.4 & 212.6 & 11.8 & 203.1 & 5.4 & 0.028 & $4.43 \%$ \\
\hline $84905-21$ & 0.5163 & 0.0202 & 0.0674 & 0.0011 & 420.4 & 7.1 & 433.3 & 17.4 & 420.4 & 7.1 & 0.020 & $2.99 \%$ \\
\hline $84905-77$ & 0.5565 & 0.0148 & 0.0718 & 0.0010 & 447.1 & 6.0 & 458.5 & 12.4 & 447.1 & 6.0 & 0.014 & $2.49 \%$ \\
\hline $84905-71$ & 0.5729 & 0.0147 & 0.0736 & 0.0010 & 457.8 & 6.3 & 468.4 & 12.2 & 457.8 & 6.3 & 0.013 & $2.28 \%$ \\
\hline $84905-76$ & 0.6419 & 0.0214 & 0.0805 & 0.0017 & 499.3 & 10.6 & 520.5 & 18.6 & 499.3 & 10.6 & 0.018 & $4.06 \%$ \\
\hline 84905-59 & 0.7114 & 0.0177 & 0.0877 & 0.0015 & 541.9 & 9.3 & 558.8 & 14.9 & 541.9 & 9.3 & 0.013 & $3.02 \%$ \\
\hline $84905-51$ & 0.7037 & 0.0227 & 0.0879 & 0.0025 & 543.0 & 15.6 & 532.8 & 17.4 & 543.0 & 15.6 & 0.016 & $-1.92 \%$ \\
\hline $84905-19$ & 0.8268 & 0.0397 & 0.1002 & 0.0021 & 615.5 & 12.7 & 597.0 & 29.2 & 615.5 & 12.7 & 0.024 & $-3.10 \%$ \\
\hline $84905-46$ & 1.2810 & 0.0345 & 0.1375 & 0.0020 & 830.4 & 12.0 & 853.8 & 24.0 & 830.4 & 12.0 & 0.014 & $2.74 \%$ \\
\hline $84905-92$ & 3.9392 & 0.0604 & 0.2827 & 0.0032 & 1605.2 & 18.3 & 1641.7 & 24.7 & 1641.7 & 24.7 & 0.008 & $2.23 \%$ \\
\hline $84905-15$ & 4.2811 & 0.0955 & 0.3037 & 0.0048 & 1709.5 & 27.1 & 1665.5 & 37.7 & 1665.5 & 37.7 & 0.011 & $-2.64 \%$ \\
\hline $84905-82$ & 4.2551 & 0.0660 & 0.2952 & 0.0033 & 1667.6 & 18.9 & 1704.4 & 26.2 & 1704.4 & 26.2 & 0.008 & $2.16 \%$ \\
\hline $84905-33$ & 4.3843 & 0.0776 & 0.3038 & 0.0038 & 1710.3 & 21.3 & 1707.8 & 31.1 & 1707.8 & 31.1 & 0.009 & $-0.14 \%$ \\
\hline 84905-35 & 4.9230 & 0.1644 & 0.3177 & 0.0068 & 1778.3 & 38.2 & 1837.4 & 60.1 & 1837.4 & 60.1 & 0.016 & $3.22 \%$ \\
\hline \multicolumn{13}{|c|}{ 05ADw305a, detrital zircons, $n=100$ of 100 , Apatite to Zircon, Inc. } \\
\hline Analysis \# & $207 / 235$ & $\begin{array}{l}2 \sigma \\
\text { error } \\
(\%)\end{array}$ & $206 / 238$ & $\begin{array}{c}2 \sigma \\
\text { error } \\
(\%)\end{array}$ & $\begin{array}{c}206 / 238 \\
\text { age }\end{array}$ & $\begin{array}{l}2 \sigma \\
\text { error } \\
(\mathrm{Ma})\end{array}$ & $\begin{array}{c}\text { 207/206 } \\
\text { age }\end{array}$ & $\begin{array}{l}2 \sigma \\
\text { error } \\
(\mathrm{Ma})\end{array}$ & $\begin{array}{l}\text { Best } \\
\text { age } \\
(\mathrm{Ma})\end{array}$ & $\begin{array}{l}2 \sigma \\
\text { error } \\
(\mathrm{Ma})\end{array}$ & Error/age & $\begin{array}{c}\text { Dis- } \\
\text { cordance } \\
(\%)\end{array}$ \\
\hline $84903-94$ & 0.1265 & 0.0183 & 0.0189 & 0.0011 & 120.7 & 6.7 & 125.9 & 19.3 & 120.7 & 6.7 & 0.077 & $4.13 \%$ \\
\hline 84903-17 & 0.1292 & 0.0134 & 0.0193 & 0.0005 & 123.2 & 3.5 & 128.2 & 13.6 & 123.2 & 3.5 & 0.053 & $3.91 \%$ \\
\hline 84903-87 & 0.1359 & 0.0099 & 0.0202 & 0.0005 & 129.2 & 3.2 & 132.8 & 10.0 & 129.2 & 3.2 & 0.038 & $2.68 \%$ \\
\hline 84903-36 & 0.1380 & 0.0181 & 0.0205 & 0.0009 & 130.7 & 5.5 & 141.3 & 19.3 & 130.7 & 5.5 & 0.068 & $7.48 \%$ \\
\hline 84903-8 & 0.1379 & 0.0273 & 0.0205 & 0.0011 & 130.7 & 6.7 & 141.3 & 28.8 & 130.7 & 6.7 & 0.102 & $7.47 \%$ \\
\hline 84903-42 & 0.1390 & 0.0111 & 0.0207 & 0.0005 & 131.9 & 2.9 & 136.6 & 11.1 & 131.9 & 2.9 & 0.041 & $3.42 \%$ \\
\hline $84903-62$ & 0.1397 & 0.0170 & 0.0208 & 0.0006 & 132.4 & 3.9 & 139.9 & 17.3 & 132.4 & 3.9 & 0.062 & $5.35 \%$ \\
\hline 84903-83 & 0.1396 & 0.0102 & 0.0208 & 0.0005 & 132.5 & 3.3 & 137.0 & 10.4 & 132.5 & 3.3 & 0.038 & $3.33 \%$ \\
\hline $84903-11$ & 0.1410 & 0.0285 & 0.0210 & 0.0011 & 133.9 & 6.7 & 134.1 & 27.7 & 133.9 & 6.7 & 0.103 & $0.09 \%$ \\
\hline $84903-74$ & 0.1419 & 0.0126 & 0.0210 & 0.0007 & 134.3 & 4.5 & 143.1 & 13.3 & 134.3 & 4.5 & 0.046 & $6.14 \%$ \\
\hline $84903-76$ & 0.1431 & 0.0283 & 0.0212 & 0.0011 & 135.2 & 6.9 & 146.4 & 29.8 & 135.2 & 6.9 & 0.102 & $7.65 \%$ \\
\hline $84903-66$ & 0.1440 & 0.0097 & 0.0214 & 0.0005 & 136.3 & 3.3 & 142.6 & 9.8 & 136.3 & 3.3 & 0.034 & $4.41 \%$ \\
\hline $84903-95$ & 0.1453 & 0.0158 & 0.0217 & 0.0005 & 138.1 & 2.9 & 132.2 & 14.6 & 138.1 & 2.9 & 0.055 & $-4.44 \%$ \\
\hline $84903-90$ & 0.1465 & 0.0145 & 0.0217 & 0.0006 & 138.5 & 3.7 & 144.8 & 14.7 & 138.5 & 3.7 & 0.051 & $4.35 \%$ \\
\hline 84903-39 & 0.1466 & 0.0127 & 0.0217 & 0.0007 & 138.5 & 4.2 & 145.1 & 12.9 & 138.5 & 4.2 & 0.044 & $4.54 \%$ \\
\hline 84903-16 & 0.1476 & 0.0180 & 0.0219 & 0.0007 & 139.4 & 4.6 & 146.9 & 18.4 & 139.4 & 4.6 & 0.063 & $5.14 \%$ \\
\hline $84903-69$ & 0.1488 & 0.0074 & 0.0221 & 0.0003 & 140.7 & 2.2 & 144.2 & 7.3 & 140.7 & 2.2 & 0.025 & $2.43 \%$ \\
\hline 84903-1 & 0.1500 & 0.0226 & 0.0222 & 0.0010 & 141.3 & 6.5 & 153.1 & 23.9 & 141.3 & 6.5 & 0.078 & $7.73 \%$ \\
\hline
\end{tabular}


Table 2. U-Pb analytical data for detrital and igneous zircons, identified by sample number and lab.—Continued

\begin{tabular}{|c|c|c|c|c|c|c|c|c|c|c|c|c|}
\hline 84903-88 & 0.1497 & 0.0068 & 0.0222 & 0.0004 & 141.4 & 2.4 & 145.6 & 6.8 & 141.4 & 2.4 & 0.023 & $2.87 \%$ \\
\hline 84903-85 & 0.1504 & 0.0149 & 0.0223 & 0.0006 & 142.0 & 3.8 & 147.0 & 15.0 & 142.0 & 3.8 & 0.051 & $3.43 \%$ \\
\hline 84903-35 & 0.1517 & 0.0154 & 0.0224 & 0.0007 & 143.0 & 4.4 & 150.7 & 15.8 & 143.0 & 4.4 & 0.052 & $5.09 \%$ \\
\hline 84903-49 & 0.1523 & 0.0333 & 0.0225 & 0.0013 & 143.8 & 8.0 & 148.3 & 33.1 & 143.8 & 8.0 & 0.112 & $3.08 \%$ \\
\hline 84903-13 & 0.1529 & 0.0202 & 0.0226 & 0.0009 & 143.9 & 5.6 & 154.9 & 21.1 & 143.9 & 5.6 & 0.068 & $7.08 \%$ \\
\hline 84903-91 & 0.1526 & 0.0098 & 0.0226 & 0.0005 & 144.0 & 3.0 & 147.9 & 9.9 & 144.0 & 3.0 & 0.033 & $2.66 \%$ \\
\hline $84903-97$ & 0.1531 & 0.0234 & 0.0226 & 0.0008 & 144.0 & 5.4 & 154.1 & 24.1 & 144.0 & 5.4 & 0.078 & $6.54 \%$ \\
\hline 84903-38 & 0.1520 & 0.0118 & 0.0226 & 0.0005 & 144.1 & 3.5 & 137.1 & 11.0 & 144.1 & 3.5 & 0.040 & $-5.10 \%$ \\
\hline $84903-65$ & 0.1543 & 0.0182 & 0.0228 & 0.0007 & 145.2 & 4.7 & 154.4 & 18.7 & 145.2 & 4.7 & 0.060 & $5.99 \%$ \\
\hline $84903-70$ & 0.1557 & 0.0109 & 0.0230 & 0.0005 & 146.7 & 3.1 & 152.3 & 11.0 & 146.7 & 3.1 & 0.036 & $3.69 \%$ \\
\hline $84903-24$ & 0.1564 & 0.0163 & 0.0231 & 0.0008 & 147.1 & 4.9 & 154.7 & 16.8 & 147.1 & 4.9 & 0.054 & $4.92 \%$ \\
\hline 84903-45 & 0.1582 & 0.0128 & 0.0233 & 0.0006 & 148.7 & 4.0 & 156.3 & 13.1 & 148.7 & 4.0 & 0.042 & $4.90 \%$ \\
\hline $84903-52$ & 0.1590 & 0.0120 & 0.0234 & 0.0007 & 149.4 & 4.2 & 157.5 & 12.2 & 149.4 & 4.2 & 0.039 & $5.12 \%$ \\
\hline 84903-30 & 0.1584 & 0.0156 & 0.0235 & 0.0008 & 149.9 & 4.8 & 140.0 & 14.3 & 149.9 & 4.8 & 0.051 & $-7.06 \%$ \\
\hline 84903-99 & 0.1594 & 0.0188 & 0.0235 & 0.0006 & 149.9 & 4.1 & 155.0 & 18.7 & 149.9 & 4.1 & 0.060 & $3.31 \%$ \\
\hline 84903-92 & 0.1599 & 0.0158 & 0.0236 & 0.0008 & 150.1 & 5.1 & 158.2 & 16.3 & 150.1 & 5.1 & 0.052 & $5.14 \%$ \\
\hline 84903-47 & 0.1601 & 0.0115 & 0.0236 & 0.0006 & 150.5 & 3.6 & 155.2 & 11.5 & 150.5 & 3.6 & 0.037 & $2.99 \%$ \\
\hline $84903-56$ & 0.1625 & 0.0303 & 0.0239 & 0.0010 & 152.3 & 6.4 & 163.9 & 31.1 & 152.3 & 6.4 & 0.095 & $7.10 \%$ \\
\hline $84903-78$ & 0.1637 & 0.0185 & 0.0241 & 0.0010 & 153.4 & 6.6 & 162.4 & 18.9 & 153.4 & 6.6 & 0.058 & $5.54 \%$ \\
\hline $84903-84$ & 0.1632 & 0.0135 & 0.0242 & 0.0006 & 153.9 & 4.1 & 148.7 & 12.5 & 153.9 & 4.1 & 0.042 & $-3.47 \%$ \\
\hline $84903-23$ & 0.1657 & 0.0229 & 0.0243 & 0.0013 & 154.8 & 8.1 & 169.3 & 24.3 & 154.8 & 8.1 & 0.072 & $8.56 \%$ \\
\hline $84903-25$ & 0.1676 & 0.0178 & 0.0246 & 0.0008 & 156.9 & 5.0 & 164.2 & 18.0 & 156.9 & 5.0 & 0.055 & $4.44 \%$ \\
\hline $84903-73$ & 0.1684 & 0.0145 & 0.0247 & 0.0007 & 157.6 & 4.4 & 166.1 & 14.8 & 157.6 & 4.4 & 0.044 & $5.14 \%$ \\
\hline $84903-50$ & 0.1689 & 0.0095 & 0.0248 & 0.0006 & 157.9 & 3.9 & 164.3 & 9.6 & 157.9 & 3.9 & 0.029 & $3.87 \%$ \\
\hline $84903-64$ & 0.1692 & 0.0124 & 0.0249 & 0.0007 & 158.3 & 4.2 & 165.3 & 12.6 & 158.3 & 4.2 & 0.038 & $4.24 \%$ \\
\hline 84903-3 & 0.1693 & 0.0116 & 0.0249 & 0.0006 & 158.4 & 3.6 & 165.0 & 11.6 & 158.4 & 3.6 & 0.035 & $3.94 \%$ \\
\hline $84903-100$ & 0.1701 & 0.0272 & 0.0250 & 0.0011 & 158.9 & 7.1 & 168.5 & 27.9 & 158.9 & 7.1 & 0.083 & $5.68 \%$ \\
\hline $84903-67$ & 0.1746 & 0.0390 & 0.0255 & 0.0014 & 162.4 & 9.0 & 178.5 & 40.7 & 162.4 & 9.0 & 0.114 & $9.06 \%$ \\
\hline 84903-5 & 0.1747 & 0.0610 & 0.0256 & 0.0018 & 163.1 & 11.2 & 169.5 & 60.2 & 163.1 & 11.2 & 0.178 & $3.77 \%$ \\
\hline $84903-86$ & 0.1764 & 0.0137 & 0.0258 & 0.0007 & 164.5 & 4.5 & 172.1 & 13.7 & 164.5 & 4.5 & 0.040 & $4.45 \%$ \\
\hline $84903-40$ & 0.1794 & 0.0193 & 0.0262 & 0.0011 & 166.9 & 6.7 & 178.1 & 19.8 & 166.9 & 6.7 & 0.056 & $6.27 \%$ \\
\hline 84903-22 & 0.1791 & 0.0120 & 0.0263 & 0.0005 & 167.1 & 3.1 & 171.5 & 11.8 & 167.1 & 3.1 & 0.034 & $2.60 \%$ \\
\hline 84903-41 & 0.1804 & 0.0203 & 0.0264 & 0.0009 & 168.2 & 5.9 & 171.5 & 19.8 & 168.2 & 5.9 & 0.058 & $1.91 \%$ \\
\hline 84903-51 & 0.1812 & 0.0098 & 0.0266 & 0.0005 & 169.0 & 3.0 & 172.3 & 9.5 & 169.0 & 3.0 & 0.028 & $1.91 \%$ \\
\hline 84903-6 & 0.1818 & 0.0074 & 0.0267 & 0.0004 & 169.6 & 2.2 & 171.3 & 7.2 & 169.6 & 2.2 & 0.021 & $1.00 \%$ \\
\hline 84903-82 & 0.1826 & 0.0151 & 0.0267 & 0.0008 & 169.7 & 4.8 & 178.7 & 15.0 & 169.7 & 4.8 & 0.042 & $5.01 \%$ \\
\hline $84903-48$ & 0.1841 & 0.0203 & 0.0269 & 0.0008 & 171.1 & 5.0 & 179.0 & 20.1 & 171.1 & 5.0 & 0.056 & $4.41 \%$ \\
\hline $84903-57$ & 0.1847 & 0.0186 & 0.0269 & 0.0009 & 171.3 & 5.9 & 182.4 & 19.1 & 171.3 & 5.9 & 0.052 & $6.08 \%$ \\
\hline 84903-46 & 0.1832 & 0.0176 & 0.0270 & 0.0010 & 171.7 & 6.1 & 159.3 & 15.9 & 171.7 & 6.1 & 0.050 & $-7.77 \%$ \\
\hline 84903-71 & 0.1855 & 0.0203 & 0.0271 & 0.0007 & 172.3 & 4.5 & 180.5 & 20.1 & 172.3 & 4.5 & 0.056 & $4.55 \%$ \\
\hline 84903-34 & 0.1854 & 0.0119 & 0.0272 & 0.0006 & 172.9 & 3.7 & 170.7 & 11.3 & 172.9 & 3.7 & 0.033 & $-1.30 \%$ \\
\hline $84903-19$ & 0.1880 & 0.0141 & 0.0274 & 0.0011 & 174.2 & 6.8 & 185.9 & 14.5 & 174.2 & 6.8 & 0.039 & $6.30 \%$ \\
\hline 84903-37 & 0.1866 & 0.0109 & 0.0274 & 0.0006 & 174.3 & 3.6 & 167.1 & 10.1 & 174.3 & 3.6 & 0.030 & $-4.29 \%$ \\
\hline 84903-32 & 0.1884 & 0.0218 & 0.0275 & 0.0008 & 174.7 & 5.2 & 183.1 & 21.4 & 174.7 & 5.2 & 0.058 & $4.60 \%$ \\
\hline 84903-44 & 0.1899 & 0.0134 & 0.0277 & 0.0006 & 176.2 & 4.1 & 182.2 & 13.1 & 176.2 & 4.1 & 0.036 & $3.27 \%$ \\
\hline 84903-33 & 0.1914 & 0.0118 & 0.0279 & 0.0005 & 177.7 & 3.2 & 181.4 & 11.5 & 177.7 & 3.2 & 0.032 & $2.07 \%$ \\
\hline $84903-54$ & 0.1937 & 0.0147 & 0.0282 & 0.0007 & 179.3 & 4.7 & 187.2 & 14.4 & 179.3 & 4.7 & 0.038 & $4.25 \%$ \\
\hline 84903-53 & 0.1957 & 0.0113 & 0.0285 & 0.0007 & 181.0 & 4.2 & 189.2 & 11.3 & 181.0 & 4.2 & 0.030 & $4.34 \%$ \\
\hline 84903-93 & 0.1957 & 0.0134 & 0.0285 & 0.0007 & 181.1 & 4.6 & 186.4 & 13.1 & 181.1 & 4.6 & 0.035 & $2.82 \%$ \\
\hline $84903-18$ & 0.1966 & 0.0149 & 0.0286 & 0.0007 & 181.8 & 4.3 & 188.1 & 14.6 & 181.8 & 4.3 & 0.039 & $3.36 \%$ \\
\hline $84903-59$ & 0.1968 & 0.0091 & 0.0287 & 0.0005 & 182.2 & 3.0 & 186.1 & 8.8 & 182.2 & 3.0 & 0.024 & $2.10 \%$ \\
\hline 84903-80 & 0.1970 & 0.0057 & 0.0287 & 0.0003 & 182.3 & 2.2 & 186.5 & 5.6 & 182.3 & 2.2 & 0.015 & $2.26 \%$ \\
\hline 84903-15 & 0.1969 & 0.0187 & 0.0287 & 0.0007 & 182.5 & 4.5 & 183.5 & 17.8 & 182.5 & 4.5 & 0.049 & $0.55 \%$ \\
\hline 84903-20 & 0.2036 & 0.0178 & 0.0295 & 0.0010 & 187.4 & 6.3 & 198.7 & 17.8 & 187.4 & 6.3 & 0.045 & $5.70 \%$ \\
\hline 84903-77 & 0.2041 & 0.0080 & 0.0297 & 0.0005 & 188.6 & 3.0 & 189.1 & 7.7 & 188.6 & 3.0 & 0.020 & $0.27 \%$ \\
\hline 84903-28 & 0.2074 & 0.0183 & 0.0301 & 0.0007 & 190.9 & 4.4 & 197.0 & 17.7 & 190.9 & 4.4 & 0.045 & $3.09 \%$ \\
\hline 84903-72 & 0.2087 & 0.0348 & 0.0301 & 0.0017 & 191.0 & 10.6 & 211.5 & 35.5 & 191.0 & 10.6 & 0.084 & $9.70 \%$ \\
\hline 84903-61 & 0.2084 & 0.0099 & 0.0302 & 0.0006 & 191.9 & 3.6 & 197.0 & 9.6 & 191.9 & 3.6 & 0.024 & $2.59 \%$ \\
\hline $84903-4$ & 0.2156 & 0.0347 & 0.0311 & 0.0014 & 197.5 & 9.1 & 206.7 & 34.4 & 197.5 & 9.1 & 0.083 & $4.43 \%$ \\
\hline $84903-26$ & 0.2182 & 0.0209 & 0.0315 & 0.0007 & 199.8 & 4.3 & 208.0 & 20.3 & 199.8 & 4.3 & 0.049 & $3.93 \%$ \\
\hline 84903-29 & 0.2179 & 0.0042 & 0.0315 & 0.0004 & 200.1 & 2.6 & 202.3 & 4.0 & 200.1 & 2.6 & 0.010 & $1.10 \%$ \\
\hline 84903-31 & 0.2330 & 0.0205 & 0.0334 & 0.0009 & 211.9 & 5.8 & 221.0 & 20.1 & 211.9 & 5.8 & 0.045 & $4.08 \%$ \\
\hline 84903-98 & 1.4581 & 0.0468 & 0.1498 & 0.0038 & 900.1 & 22.9 & 945.5 & 32.5 & 900.1 & 22.9 & 0.017 & $4.80 \%$ \\
\hline 84903-55 & 1.4414 & 0.0367 & 0.1509 & 0.0027 & 905.9 & 16.3 & 908.1 & 23.6 & 905.9 & 16.3 & 0.013 & $0.24 \%$ \\
\hline $84903-75$ & 1.5419 & 0.0934 & 0.1570 & 0.0048 & 940.0 & 28.7 & 964.4 & 58.2 & 940.0 & 28.7 & 0.030 & $2.54 \%$ \\
\hline $84903-58$ & 1.5377 & 0.0353 & 0.1572 & 0.0027 & 941.0 & 15.9 & 957.0 & 22.2 & 941.0 & 15.9 & 0.012 & $1.67 \%$ \\
\hline 84903-96 & 1.5617 & 0.0347 & 0.1582 & 0.0024 & 946.8 & 14.4 & 974.7 & 21.9 & 946.8 & 14.4 & 0.011 & $2.87 \%$ \\
\hline 84903-43 & 2.1170 & 0.0708 & 0.1989 & 0.0036 & 1169.4 & 21.4 & 1126.4 & 40.1 & 1126.4 & 40.1 & 0.018 & $-3.81 \%$ \\
\hline 84903-21 & 2.6951 & 0.1177 & 0.2321 & 0.0062 & 1345.3 & 35.7 & 1298.9 & 56.5 & 1298.9 & 56.5 & 0.022 & $-3.57 \%$ \\
\hline 84903-10 & 2.9883 & 0.1033 & 0.2409 & 0.0053 & 1391.2 & 30.4 & 1425.3 & 51.1 & 1425.3 & 51.1 & 0.018 & $2.39 \%$ \\
\hline $84903-14$ & 3.3614 & 0.1344 & 0.2593 & 0.0087 & 1486.5 & 49.6 & 1509.5 & 50.9 & 1509.5 & 50.9 & 0.017 & $1.53 \%$ \\
\hline 84903-63 & 4.0674 & 0.1802 & 0.2961 & 0.0064 & 1672.0 & 36.3 & 1617.2 & 74.0 & 1617.2 & 74.0 & 0.023 & $-3.39 \%$ \\
\hline
\end{tabular}


Table 2. U-Pb analytical data for detrital and igneous zircons, identified by sample number and lab.—Continued

\begin{tabular}{|c|c|c|c|c|c|c|c|c|c|c|c|c|}
\hline $84903-81$ & 4.1522 & 0.1393 & 0.2949 & 0.0089 & 1665.9 & 50.4 & 1663.2 & 58.0 & 1663.2 & 58.0 & 0.017 & $-0.16 \%$ \\
\hline $84903-12$ & 4.1464 & 0.0848 & 0.2911 & 0.0042 & 1647.2 & 23.7 & 1685.3 & 37.1 & 1685.3 & 37.1 & 0.011 & $2.26 \%$ \\
\hline 84903-2 & 4.3989 & 0.0858 & 0.3065 & 0.0042 & 1723.6 & 23.4 & 1699.3 & 35.1 & 1699.3 & 35.1 & 0.010 & $-1.43 \%$ \\
\hline 84903-79 & 4.3285 & 0.1549 & 0.2982 & 0.0089 & 1682.6 & 50.2 & 1719.2 & 64.5 & 1719.2 & 64.5 & 0.019 & $2.13 \%$ \\
\hline $84903-60$ & 4.6775 & 0.1529 & 0.3092 & 0.0053 & 1736.7 & 29.9 & 1795.5 & 60.9 & 1795.5 & 60.9 & 0.017 & $3.27 \%$ \\
\hline 84903-7 & 5.2508 & 0.1337 & 0.3338 & 0.0059 & 1857.0 & 32.9 & 1865.4 & 48.3 & 1865.4 & 48.3 & 0.013 & $0.45 \%$ \\
\hline $84903-68$ & 6.0701 & 0.1570 & 0.3557 & 0.0062 & 1961.8 & 33.9 & 2011.4 & 52.7 & 2011.4 & 52.7 & 0.013 & $2.47 \%$ \\
\hline $84903-27$ & 13.3195 & 0.3980 & 0.5137 & 0.0097 & 2672.3 & 50.6 & 2725.5 & 86.1 & 2725.5 & 86.1 & 0.016 & $1.95 \%$ \\
\hline 84903-89 & 13.3195 & 0.3980 & 0.5137 & 0.0097 & 2672.3 & 50.6 & 2725.5 & 86.1 & 2725.5 & 86.1 & 0.016 & $1.95 \%$ \\
\hline 84903-9 & 14.7223 & 0.3808 & 0.5367 & 0.0095 & 2769.8 & 48.9 & 2817.7 & 75.6 & 2817.7 & 75.6 & 0.013 & $1.70 \%$ \\
\hline \multicolumn{13}{|c|}{ 05ADw303c, detrital zircons, $n=97$ of 100, Apatite to Zircon, Inc. } \\
\hline Analysis \# & $207 / 235$ & $\begin{array}{c}2 \sigma \\
\text { error } \\
(\%)\end{array}$ & $206 / 238$ & $\begin{array}{c}2 \sigma \\
\text { error } \\
(\%)\end{array}$ & $\begin{array}{c}206 / 238 \\
\text { age }\end{array}$ & $\begin{array}{c}2 \sigma \\
\text { error } \\
(\mathrm{Ma})\end{array}$ & $\begin{array}{c}207 / 206 \\
\text { age }\end{array}$ & $\begin{array}{l}2 \sigma \\
\text { error } \\
(\mathrm{Ma})\end{array}$ & $\begin{array}{l}\text { Best } \\
\text { age } \\
(\mathrm{Ma})\end{array}$ & $\begin{array}{l}2 \sigma \\
\text { error } \\
(\mathrm{Ma})\end{array}$ & Error/age & $\begin{array}{c}\text { Dis- } \\
\text { cordance } \\
(\%)\end{array}$ \\
\hline $84901-71$ & 0.1396 & 0.0200 & 0.0207 & 0.0011 & 132.1 & 7.2 & 144.0 & 21.8 & 132.1 & 7.2 & 0.076 & $8.22 \%$ \\
\hline $84901-82$ & 0.1413 & 0.0307 & 0.0210 & 0.0006 & 134.0 & 3.8 & 138.7 & 30.3 & 134.0 & 3.8 & 0.109 & $3.38 \%$ \\
\hline $84901-73$ & 0.1423 & 0.0311 & 0.0210 & 0.0015 & 134.2 & 9.9 & 151.3 & 34.5 & 134.2 & 9.9 & 0.114 & $11.27 \%$ \\
\hline 84901-3 & 0.1444 & 0.0116 & 0.0215 & 0.0004 & 136.8 & 2.8 & 140.1 & 11.6 & 136.8 & 2.8 & 0.041 & $2.32 \%$ \\
\hline $84901-55$ & 0.1446 & 0.0089 & 0.0215 & 0.0005 & 137.0 & 3.3 & 139.2 & 8.9 & 137.0 & 3.3 & 0.032 & $1.52 \%$ \\
\hline $84901-34$ & 0.1470 & 0.0357 & 0.0218 & 0.0006 & 138.9 & 4.0 & 146.7 & 35.8 & 138.9 & 4.0 & 0.122 & $5.35 \%$ \\
\hline $84901-33$ & 0.1481 & 0.0158 & 0.0219 & 0.0008 & 139.7 & 5.0 & 149.2 & 16.6 & 139.7 & 5.0 & 0.056 & $6.36 \%$ \\
\hline $84901-48$ & 0.1498 & 0.0112 & 0.0222 & 0.0005 & 141.5 & 3.4 & 147.9 & 11.4 & 141.5 & 3.4 & 0.039 & $4.38 \%$ \\
\hline $84901-27$ & 0.1501 & 0.0178 & 0.0222 & 0.0008 & 141.7 & 5.0 & 149.9 & 18.5 & 141.7 & 5.0 & 0.062 & $5.51 \%$ \\
\hline $84901-38$ & 0.1501 & 0.0101 & 0.0222 & 0.0007 & 141.7 & 4.2 & 148.0 & 10.1 & 141.7 & 4.2 & 0.034 & $4.23 \%$ \\
\hline $84901-94$ & 0.1508 & 0.0166 & 0.0223 & 0.0008 & 142.1 & 5.4 & 152.1 & 17.5 & 142.1 & 5.4 & 0.058 & $6.57 \%$ \\
\hline $84901-85$ & 0.1516 & 0.0109 & 0.0224 & 0.0007 & 142.9 & 4.2 & 150.2 & 11.0 & 142.9 & 4.2 & 0.037 & $4.87 \%$ \\
\hline $84901-57$ & 0.1526 & 0.0174 & 0.0226 & 0.0008 & 143.8 & 5.3 & 152.1 & 18.0 & 143.8 & 5.3 & 0.059 & $5.41 \%$ \\
\hline $84901-46$ & 0.1525 & 0.0098 & 0.0226 & 0.0005 & 144.0 & 3.0 & 147.7 & 9.8 & 144.0 & 3.0 & 0.033 & $2.52 \%$ \\
\hline $84901-45$ & 0.1525 & 0.0103 & 0.0226 & 0.0004 & 144.0 & 2.9 & 147.8 & 10.3 & 144.0 & 2.9 & 0.035 & $2.54 \%$ \\
\hline $84901-35$ & 0.1532 & 0.0089 & 0.0227 & 0.0005 & 144.6 & 3.0 & 148.2 & 8.9 & 144.6 & 3.0 & 0.030 & $2.39 \%$ \\
\hline $84901-83$ & 0.1544 & 0.0090 & 0.0228 & 0.0004 & 145.6 & 2.7 & 150.8 & 9.1 & 145.6 & 2.7 & 0.030 & $3.44 \%$ \\
\hline $84901-100$ & 0.1549 & 0.0201 & 0.0229 & 0.0007 & 145.8 & 4.3 & 152.7 & 20.2 & 145.8 & 4.3 & 0.066 & $4.52 \%$ \\
\hline $84901-22$ & 0.1551 & 0.0161 & 0.0229 & 0.0007 & 145.9 & 4.6 & 154.7 & 16.5 & 145.9 & 4.6 & 0.053 & $5.68 \%$ \\
\hline $84901-69$ & 0.1554 & 0.0089 & 0.0230 & 0.0004 & 146.5 & 2.8 & 150.2 & 8.8 & 146.5 & 2.8 & 0.029 & $2.45 \%$ \\
\hline $84901-11$ & 0.1571 & 0.0158 & 0.0232 & 0.0005 & 147.9 & 3.3 & 153.2 & 15.6 & 147.9 & 3.3 & 0.051 & $3.45 \%$ \\
\hline $84901-31$ & 0.1577 & 0.0117 & 0.0233 & 0.0005 & 148.5 & 3.2 & 153.0 & 11.7 & 148.5 & 3.2 & 0.038 & $2.89 \%$ \\
\hline $84901-87$ & 0.1581 & 0.0121 & 0.0233 & 0.0006 & 148.6 & 3.7 & 155.6 & 12.4 & 148.6 & 3.7 & 0.040 & $4.48 \%$ \\
\hline 84901-1 & 0.1601 & 0.0216 & 0.0234 & 0.0025 & 149.0 & 15.7 & 178.2 & 24.6 & 148.0 & 15.7 & 0.069 & $16.39 \%$ \\
\hline $84901-51$ & 0.1587 & 0.0116 & 0.0234 & 0.0006 & 149.3 & 3.9 & 156.4 & 11.7 & 149.3 & 3.9 & 0.037 & $4.56 \%$ \\
\hline $84901-91$ & 0.1592 & 0.0131 & 0.0235 & 0.0007 & 149.7 & 4.3 & 155.6 & 13.2 & 149.7 & 4.3 & 0.042 & $3.82 \%$ \\
\hline $84901-47$ & 0.1595 & 0.0090 & 0.0235 & 0.0004 & 150.0 & 2.7 & 155.0 & 9.0 & 150.0 & 2.7 & 0.029 & $3.23 \%$ \\
\hline $84901-24$ & 0.1627 & 0.0137 & 0.0240 & 0.0006 & 152.9 & 3.9 & 157.9 & 13.6 & 152.9 & 3.9 & 0.043 & $3.16 \%$ \\
\hline $84901-78$ & 0.1633 & 0.0159 & 0.0240 & 0.0007 & 153.1 & 4.6 & 161.5 & 15.9 & 153.1 & 4.6 & 0.049 & $5.23 \%$ \\
\hline $84901-53$ & 0.1636 & 0.0148 & 0.0241 & 0.0007 & 153.4 & 4.3 & 161.1 & 14.8 & 153.4 & 4.3 & 0.046 & $4.82 \%$ \\
\hline $84901-42$ & 0.1638 & 0.0163 & 0.0241 & 0.0009 & 153.6 & 5.5 & 163.3 & 16.9 & 153.6 & 5.5 & 0.052 & $5.99 \%$ \\
\hline $84901-21$ & 0.1663 & 0.0205 & 0.0244 & 0.0011 & 155.5 & 7.3 & 167.9 & 22.0 & 155.5 & 7.3 & 0.065 & $7.40 \%$ \\
\hline $84901-15$ & 0.1674 & 0.0155 & 0.0246 & 0.0007 & 156.6 & 4.8 & 165.7 & 15.9 & 156.6 & 4.8 & 0.048 & $5.50 \%$ \\
\hline 84901-6 & 0.1681 & 0.0169 & 0.0247 & 0.0005 & 157.4 & 3.3 & 164.0 & 16.8 & 157.4 & 3.3 & 0.051 & $3.98 \%$ \\
\hline $84901-92$ & 0.1710 & 0.0110 & 0.0251 & 0.0008 & 159.8 & 4.9 & 167.4 & 10.8 & 159.8 & 4.9 & 0.032 & $4.53 \%$ \\
\hline $84901-25$ & 0.1720 & 0.0084 & 0.0253 & 0.0006 & 160.9 & 3.8 & 166.9 & 8.3 & 160.9 & 3.8 & 0.025 & $3.64 \%$ \\
\hline $84901-67$ & 0.1721 & 0.0101 & 0.0253 & 0.0005 & 161.1 & 3.4 & 165.1 & 10.0 & 161.1 & 3.4 & 0.030 & $2.41 \%$ \\
\hline $84901-97$ & 0.1735 & 0.0120 & 0.0255 & 0.0006 & 162.0 & 3.7 & 168.7 & 11.9 & 162.0 & 3.7 & 0.035 & $3.94 \%$ \\
\hline $84901-93$ & 0.1748 & 0.0088 & 0.0256 & 0.0007 & 163.1 & 4.5 & 171.1 & 8.7 & 163.1 & 4.5 & 0.025 & $4.67 \%$ \\
\hline $84901-26$ & 0.1772 & 0.0112 & 0.0260 & 0.0008 & 165.2 & 4.9 & 172.4 & 10.9 & 165.2 & 4.9 & 0.032 & $4.13 \%$ \\
\hline $84901-29$ & 0.1783 & 0.0099 & 0.0261 & 0.0007 & 166.1 & 4.5 & 174.7 & 9.9 & 166.1 & 4.5 & 0.028 & $4.93 \%$ \\
\hline $84901-58$ & 0.1789 & 0.0178 & 0.0262 & 0.0011 & 166.5 & 6.7 & 177.9 & 18.3 & 166.5 & 6.7 & 0.052 & $6.43 \%$ \\
\hline $84901-8$ & 0.1787 & 0.0151 & 0.0262 & 0.0006 & 167.0 & 4.1 & 166.8 & 14.3 & 167.0 & 4.1 & 0.043 & $-0.14 \%$ \\
\hline $84901-30$ & 0.1804 & 0.0298 & 0.0263 & 0.0017 & 167.2 & 10.6 & 186.8 & 31.9 & 167.2 & 10.6 & 0.085 & $10.53 \%$ \\
\hline $84901-63$ & 0.1821 & 0.0142 & 0.0266 & 0.0007 & 169.4 & 4.6 & 177.3 & 14.2 & 169.4 & 4.6 & 0.040 & $4.46 \%$ \\
\hline $84901-79$ & 0.1844 & 0.0314 & 0.0269 & 0.0013 & 170.8 & 8.4 & 185.6 & 32.1 & 170.8 & 8.4 & 0.086 & $7.93 \%$ \\
\hline $84901-7$ & 0.1849 & 0.0176 & 0.0270 & 0.0006 & 171.8 & 3.9 & 179.7 & 17.5 & 171.8 & 3.9 & 0.049 & $4.39 \%$ \\
\hline $84901-88$ & 0.1866 & 0.0092 & 0.0272 & 0.0007 & 173.3 & 4.2 & 181.4 & 9.2 & 173.3 & 4.2 & 0.025 & $4.43 \%$ \\
\hline $84901-19$ & 0.1877 & 0.0161 & 0.0274 & 0.0009 & 174.0 & 5.6 & 183.6 & 16.0 & 174.0 & 5.6 & 0.044 & $5.23 \%$ \\
\hline $84901-43$ & 0.1879 & 0.0197 & 0.0274 & 0.0008 & 174.2 & 5.0 & 183.9 & 19.9 & 174.2 & 5.0 & 0.054 & $5.26 \%$ \\
\hline $84901-65$ & 0.1886 & 0.0148 & 0.0275 & 0.0007 & 174.9 & 4.6 & 183.3 & 14.8 & 174.9 & 4.6 & 0.040 & $4.61 \%$ \\
\hline $84901-44$ & 0.1886 & 0.0095 & 0.0275 & 0.0007 & 175.1 & 4.2 & 182.1 & 9.4 & 175.1 & 4.2 & 0.026 & $3.87 \%$ \\
\hline $84901-49$ & 0.1891 & 0.0078 & 0.0276 & 0.0005 & 175.6 & 2.9 & 180.2 & 7.7 & 175.6 & 2.9 & 0.021 & $2.53 \%$ \\
\hline $84901-12$ & 0.1896 & 0.0095 & 0.0277 & 0.0005 & 176.0 & 3.1 & 180.4 & 9.3 & 176.0 & 3.1 & 0.026 & $2.42 \%$ \\
\hline $84901-61$ & 0.1900 & 0.0061 & 0.0277 & 0.0006 & 176.4 & 3.9 & 181.8 & 6.0 & 176.4 & 3.9 & 0.017 & $2.97 \%$ \\
\hline $84901-96$ & 0.1911 & 0.0326 & 0.0278 & 0.0014 & 176.6 & 8.7 & 191.7 & 33.1 & 176.6 & 8.7 & 0.086 & $7.88 \%$ \\
\hline $84901-70$ & 0.1916 & 0.0128 & 0.0279 & 0.0008 & 177.6 & 4.9 & 185.8 & 12.8 & 177.6 & 4.9 & 0.034 & $4.41 \%$ \\
\hline $84901-56$ & 0.1913 & 0.0059 & 0.0279 & 0.0004 & 177.6 & 2.5 & 181.9 & 5.6 & 177.6 & 2.5 & 0.015 & $2.35 \%$ \\
\hline
\end{tabular}


Table 2. U-Pb analytical data for detrital and igneous zircons, identified by sample number and lab.—Continued

\begin{tabular}{|c|c|c|c|c|c|c|c|c|c|c|c|c|}
\hline $84901-99$ & 0.1922 & 0.0176 & 0.0280 & 0.0006 & 178.1 & 4.0 & 184.9 & 17.3 & 178.1 & 4.0 & 0.047 & $3.66 \%$ \\
\hline $84901-17$ & 0.1926 & 0.0141 & 0.0280 & 0.0007 & 178.3 & 4.2 & 185.7 & 14.0 & 178.3 & 4.2 & 0.038 & $3.98 \%$ \\
\hline $84901-9$ & 0.1909 & 0.0119 & 0.0281 & 0.0011 & 178.4 & 7.3 & 165.1 & 10.8 & 178.4 & 7.3 & 0.033 & $-8.05 \%$ \\
\hline $84901-20$ & 0.1938 & 0.0129 & 0.0282 & 0.0007 & 179.5 & 4.2 & 186.5 & 12.9 & 179.5 & 4.2 & 0.034 & $3.79 \%$ \\
\hline $84901-37$ & 0.1937 & 0.0099 & 0.0282 & 0.0006 & 179.5 & 3.8 & 185.1 & 9.9 & 179.5 & 3.8 & 0.027 & $3.00 \%$ \\
\hline $84901-64$ & 0.1944 & 0.0083 & 0.0283 & 0.0008 & 180.0 & 4.8 & 186.0 & 8.1 & 180.0 & 4.8 & 0.022 & $3.23 \%$ \\
\hline $84901-98$ & 0.1956 & 0.0087 & 0.0285 & 0.0005 & 181.1 & 3.5 & 185.7 & 8.5 & 181.1 & 3.5 & 0.023 & $2.49 \%$ \\
\hline $84901-59$ & 0.1961 & 0.0180 & 0.0285 & 0.0009 & 181.2 & 5.7 & 191.1 & 18.2 & 181.2 & 5.7 & 0.048 & $5.20 \%$ \\
\hline $84901-28$ & 0.1970 & 0.0069 & 0.0287 & 0.0005 & 182.5 & 2.9 & 184.6 & 6.6 & 182.5 & 2.9 & 0.018 & $1.18 \%$ \\
\hline $84901-32$ & 0.1974 & 0.0117 & 0.0287 & 0.0009 & 182.5 & 5.7 & 188.4 & 11.8 & 182.5 & 5.7 & 0.031 & $3.13 \%$ \\
\hline $84901-36$ & 0.1985 & 0.0090 & 0.0289 & 0.0007 & 183.4 & 4.6 & 192.1 & 9.3 & 183.4 & 4.6 & 0.024 & $4.54 \%$ \\
\hline 84901-2 & 0.1989 & 0.0161 & 0.0289 & 0.0009 & 183.5 & 5.5 & 193.9 & 16.1 & 183.5 & 5.5 & 0.042 & $5.37 \%$ \\
\hline $84901-90$ & 0.1990 & 0.0093 & 0.0289 & 0.0006 & 183.9 & 3.7 & 190.0 & 9.3 & 183.9 & 3.7 & 0.024 & $3.17 \%$ \\
\hline $84901-4$ & 0.1998 & 0.0111 & 0.0291 & 0.0007 & 184.7 & 4.2 & 190.6 & 10.8 & 184.7 & 4.2 & 0.028 & $3.10 \%$ \\
\hline $84901-54$ & 0.2006 & 0.0084 & 0.0292 & 0.0005 & 185.6 & 3.1 & 186.6 & 8.1 & 185.6 & 3.1 & 0.022 & $0.55 \%$ \\
\hline $84901-14$ & 0.2018 & 0.0328 & 0.0292 & 0.0014 & 185.7 & 8.8 & 200.6 & 33.3 & 185.7 & 8.8 & 0.083 & $7.44 \%$ \\
\hline $84901-62$ & 0.2015 & 0.0239 & 0.0294 & 0.0009 & 186.5 & 6.0 & 184.8 & 22.4 & 186.5 & 6.0 & 0.061 & $-0.92 \%$ \\
\hline $84901-13$ & 0.2020 & 0.0087 & 0.0294 & 0.0005 & 186.5 & 3.1 & 192.2 & 8.5 & 186.5 & 3.1 & 0.022 & $2.95 \%$ \\
\hline $84901-81$ & 0.2044 & 0.0176 & 0.0296 & 0.0009 & 188.1 & 5.9 & 199.1 & 17.4 & 188.1 & 5.9 & 0.044 & $5.53 \%$ \\
\hline $84901-74$ & 0.2041 & 0.0170 & 0.0296 & 0.0007 & 188.2 & 4.7 & 195.3 & 16.7 & 188.2 & 4.7 & 0.043 & $3.63 \%$ \\
\hline $84901-23$ & 0.2055 & 0.0143 & 0.0298 & 0.0007 & 189.4 & 4.7 & 196.2 & 13.9 & 189.4 & 4.7 & 0.035 & $3.50 \%$ \\
\hline $84901-18$ & 0.2055 & 0.0149 & 0.0298 & 0.0008 & 189.4 & 5.0 & 196.5 & 14.5 & 189.4 & 5.0 & 0.037 & $3.64 \%$ \\
\hline $84901-76$ & 0.2066 & 0.0218 & 0.0299 & 0.0010 & 190.1 & 6.4 & 200.1 & 21.7 & 190.1 & 6.4 & 0.054 & $5.02 \%$ \\
\hline $84901-72$ & 0.2067 & 0.0084 & 0.0300 & 0.0006 & 190.5 & 4.1 & 196.2 & 8.2 & 190.5 & 4.1 & 0.021 & $2.91 \%$ \\
\hline $84901-40$ & 0.2071 & 0.0107 & 0.0300 & 0.0007 & 190.7 & 4.3 & 198.5 & 10.4 & 190.7 & 4.3 & 0.026 & $3.96 \%$ \\
\hline $84901-39$ & 0.2085 & 0.0136 & 0.0302 & 0.0008 & 191.7 & 5.3 & 199.4 & 13.0 & 191.7 & 5.3 & 0.033 & $3.86 \%$ \\
\hline $84901-75$ & 0.2088 & 0.0111 & 0.0302 & 0.0009 & 191.9 & 5.8 & 202.3 & 10.4 & 191.9 & 5.8 & 0.026 & $5.14 \%$ \\
\hline $84901-60$ & 0.2097 & 0.0104 & 0.0304 & 0.0006 & 193.0 & 3.9 & 199.2 & 10.2 & 193.0 & 3.9 & 0.026 & $3.13 \%$ \\
\hline $84901-86$ & 0.2119 & 0.0163 & 0.0306 & 0.0010 & 194.3 & 6.4 & 204.8 & 15.9 & 194.3 & 6.4 & 0.039 & $5.11 \%$ \\
\hline $84901-10$ & 0.2109 & 0.0299 & 0.0306 & 0.0013 & 194.3 & 8.5 & 193.5 & 28.0 & 194.3 & 8.5 & 0.072 & $-0.44 \%$ \\
\hline $84901-5$ & 0.2126 & 0.0055 & 0.0308 & 0.0005 & 195.4 & 3.0 & 200.4 & 5.3 & 195.4 & 3.0 & 0.013 & $2.48 \%$ \\
\hline $84901-66$ & 0.2133 & 0.0094 & 0.0309 & 0.0006 & 196.1 & 3.7 & 200.8 & 9.2 & 196.1 & 3.7 & 0.023 & $2.34 \%$ \\
\hline $84901-77$ & 0.2146 & 0.0052 & 0.0311 & 0.0004 & 197.3 & 2.7 & 200.4 & 5.0 & 197.3 & 2.7 & 0.012 & $1.58 \%$ \\
\hline $84901-50$ & 0.2157 & 0.0177 & 0.0311 & 0.0009 & 197.6 & 5.6 & 208.6 & 17.5 & 197.6 & 5.6 & 0.042 & $5.25 \%$ \\
\hline $84901-84$ & 0.2160 & 0.0099 & 0.0312 & 0.0007 & 198.1 & 4.2 & 206.2 & 9.8 & 198.1 & 4.2 & 0.024 & $3.90 \%$ \\
\hline $84901-52$ & 0.2167 & 0.0191 & 0.0312 & 0.0011 & 198.2 & 6.9 & 210.6 & 19.0 & 198.2 & 6.9 & 0.045 & $5.89 \%$ \\
\hline $84901-68$ & 0.2168 & 0.0101 & 0.0313 & 0.0008 & 198.8 & 4.8 & 206.1 & 9.8 & 198.8 & 4.8 & 0.024 & $3.54 \%$ \\
\hline $84901-41$ & 1.6895 & 0.0607 & 0.1692 & 0.0035 & 1007.7 & 20.7 & 997.8 & 37.2 & 997.8 & 37.2 & 0.019 & $-1.00 \%$ \\
\hline $84901-89$ & 1.7393 & 0.0510 & 0.1699 & 0.0033 & 1011.5 & 19.8 & 1049.7 & 32.6 & 1049.7 & 32.6 & 0.016 & $3.64 \%$ \\
\hline $84901-95$ & 4.5608 & 0.2751 & 0.3250 & 0.0173 & 1814.3 & 96.3 & 1656.7 & 99.4 & 1656.7 & 99.4 & 0.030 & $-9.51 \%$ \\
\hline $84901-80$ & 4.7740 & 0.2665 & 0.3312 & 0.0170 & 1844.3 & 94.8 & 1706.2 & 96.3 & 1706.2 & 96.3 & 0.028 & $-8.09 \%$ \\
\hline $84901-16$ & 5.7733 & 0.2775 & 0.3435 & 0.0155 & 1903.4 & 85.8 & 1985.3 & 94.8 & 1985.3 & 94.8 & 0.024 & $4.13 \%$ \\
\hline
\end{tabular}

05ADw304a, detrital zircons, $n=96$ of 100 , Apatite to Zircon, Inc.

\begin{tabular}{|c|c|c|c|c|c|c|c|c|c|c|c|c|}
\hline Analysis \# & $207 / 235$ & $\begin{array}{c}2 \sigma \\
\text { error } \\
(\%)\end{array}$ & $206 / 238$ & $\begin{array}{c}2 \sigma \\
\text { error } \\
(\%)\end{array}$ & $\begin{array}{c}206 / 238 \\
\text { age }\end{array}$ & $\begin{array}{l}2 \sigma \\
\text { error } \\
(\mathrm{Ma})\end{array}$ & $\begin{array}{c}207 / 206 \\
\text { age }\end{array}$ & $\begin{array}{l}2 \sigma \\
\text { error } \\
\text { (Ma) }\end{array}$ & $\begin{array}{l}\text { Best } \\
\text { age } \\
(\mathrm{Ma})\end{array}$ & $\begin{array}{l}2 \sigma \\
\text { error } \\
(\mathrm{Ma})\end{array}$ & Error/age & $\begin{array}{c}\text { Dis- } \\
\text { cordance } \\
(\%)\end{array}$ \\
\hline $84902-9$ & 0.1279 & 0.0232 & 0.0190 & 0.0012 & 121.6 & 8.0 & 134.9 & 25.4 & 121.6 & 8.0 & 0.094 & $9.85 \%$ \\
\hline $84902-20$ & 0.1303 & 0.0135 & 0.0194 & 0.0006 & 124.0 & 3.8 & 130.8 & 13.9 & 124.0 & 3.8 & 0.053 & $5.21 \%$ \\
\hline $84902-26$ & 0.1400 & 0.0145 & 0.0208 & 0.0006 & 132.6 & 4.0 & 140.7 & 15.0 & 132.6 & 4.0 & 0.053 & $5.72 \%$ \\
\hline $84902-82$ & 0.1405 & 0.0219 & 0.0208 & 0.0012 & 132.8 & 7.4 & 146.9 & 23.6 & 132.8 & 7.4 & 0.080 & $9.59 \%$ \\
\hline $84902-35$ & 0.1423 & 0.0302 & 0.0210 & 0.0016 & 134.1 & 10.4 & 153.7 & 33.8 & 134.1 & 10.4 & 0.110 & $12.73 \%$ \\
\hline $84902-94$ & 0.1456 & 0.0255 & 0.0216 & 0.0010 & 137.4 & 6.3 & 149.2 & 26.8 & 137.4 & 6.3 & 0.090 & $7.90 \%$ \\
\hline $84902-87$ & 0.1460 & 0.0077 & 0.0217 & 0.0004 & 138.3 & 2.6 & 141.1 & 7.6 & 138.3 & 2.6 & 0.027 & $1.94 \%$ \\
\hline $84902-88$ & 0.1462 & 0.0084 & 0.0217 & 0.0005 & 138.4 & 3.0 & 142.7 & 8.4 & 138.4 & 3.0 & 0.029 & $3.04 \%$ \\
\hline $84902-92$ & 0.1466 & 0.0143 & 0.0217 & 0.0007 & 138.5 & 4.6 & 145.7 & 14.8 & 138.5 & 4.6 & 0.051 & $4.94 \%$ \\
\hline $84902-81$ & 0.1469 & 0.0129 & 0.0218 & 0.0005 & 138.9 & 3.5 & 145.3 & 13.0 & 138.9 & 3.5 & 0.045 & $4.43 \%$ \\
\hline $84902-57$ & 0.1474 & 0.0154 & 0.0218 & 0.0007 & 139.2 & 4.2 & 146.2 & 15.7 & 139.2 & 4.2 & 0.054 & $4.75 \%$ \\
\hline $84902-95$ & 0.1472 & 0.0142 & 0.0219 & 0.0005 & 139.4 & 3.5 & 140.4 & 13.7 & 139.4 & 3.5 & 0.049 & $0.73 \%$ \\
\hline $84902-8$ & 0.1505 & 0.0227 & 0.0222 & 0.0009 & 141.9 & 5.9 & 152.3 & 23.4 & 141.9 & 5.9 & 0.077 & $6.85 \%$ \\
\hline $84902-16$ & 0.1511 & 0.0147 & 0.0224 & 0.0005 & 142.7 & 3.5 & 148.2 & 14.8 & 142.7 & 3.5 & 0.050 & $3.71 \%$ \\
\hline $84902-14$ & 0.1513 & 0.0175 & 0.0224 & 0.0010 & 142.9 & 6.6 & 146.9 & 17.2 & 142.9 & 6.6 & 0.059 & $2.72 \%$ \\
\hline $84902-49$ & 0.1520 & 0.0147 & 0.0225 & 0.0007 & 143.3 & 4.6 & 152.5 & 15.3 & 143.3 & 4.6 & 0.050 & $6.05 \%$ \\
\hline
\end{tabular}


Table 2. U-Pb analytical data for detrital and igneous zircons, identified by sample number and lab.-Continued

\begin{tabular}{|c|c|c|c|c|c|c|c|c|c|c|c|c|}
\hline $84902-31$ & 0.1520 & 0.0108 & 0.0225 & 0.0004 & 143.4 & 2.8 & 147.6 & 10.7 & 143.4 & 2.8 & 0.036 & $2.86 \%$ \\
\hline $84902-86$ & 0.1521 & 0.0168 & 0.0226 & 0.0006 & 143.9 & 4.0 & 140.7 & 15.8 & 143.9 & 4.0 & 0.056 & $-2.30 \%$ \\
\hline $84902-90$ & 0.1531 & 0.0128 & 0.0226 & 0.0006 & 144.3 & 3.6 & 150.5 & 13.0 & 144.3 & 3.6 & 0.043 & $4.09 \%$ \\
\hline $84902-84$ & 0.1538 & 0.0077 & 0.0228 & 0.0005 & 145.2 & 3.4 & 149.3 & 7.7 & 145.2 & 3.4 & 0.026 & $2.78 \%$ \\
\hline $84902-7$ & 0.1543 & 0.0168 & 0.0228 & 0.0009 & 145.3 & 5.6 & 154.2 & 17.3 & 145.3 & 5.6 & 0.056 & $5.80 \%$ \\
\hline $84902-17$ & 0.1542 & 0.0169 & 0.0228 & 0.0007 & 145.3 & 4.4 & 151.8 & 17.2 & 145.3 & 4.4 & 0.057 & $4.29 \%$ \\
\hline 84902-76 & 0.1542 & 0.0068 & 0.0228 & 0.0004 & 145.5 & 2.8 & 149.3 & 6.8 & 145.5 & 2.8 & 0.023 & $2.54 \%$ \\
\hline $84902-25$ & 0.1549 & 0.0155 & 0.0229 & 0.0009 & 145.7 & 6.0 & 155.5 & 16.4 & 145.7 & 6.0 & 0.053 & $6.31 \%$ \\
\hline 84902-78 & 0.1548 & 0.0107 & 0.0229 & 0.0005 & 145.9 & 3.2 & 151.7 & 10.8 & 145.9 & 3.2 & 0.036 & $3.84 \%$ \\
\hline $84902-72$ & 0.1552 & 0.0145 & 0.0230 & 0.0005 & 146.4 & 3.4 & 150.9 & 14.4 & 146.4 & 3.4 & 0.048 & $3.00 \%$ \\
\hline $84902-66$ & 0.1562 & 0.0456 & 0.0230 & 0.0015 & 146.4 & 9.4 & 164.6 & 49.0 & 146.4 & 9.4 & 0.149 & $11.04 \%$ \\
\hline $84902-85$ & 0.1560 & 0.0143 & 0.0231 & 0.0005 & 147.0 & 3.3 & 153.1 & 14.3 & 147.0 & 3.3 & 0.047 & $3.98 \%$ \\
\hline $84902-5$ & 0.1567 & 0.0159 & 0.0231 & 0.0009 & 147.2 & 5.8 & 157.6 & 16.5 & 147.2 & 5.8 & 0.052 & $6.63 \%$ \\
\hline $84902-83$ & 0.1573 & 0.0205 & 0.0232 & 0.0009 & 147.8 & 5.8 & 157.3 & 21.1 & 147.8 & 5.8 & 0.067 & $6.06 \%$ \\
\hline $84902-6$ & 0.1574 & 0.0179 & 0.0232 & 0.0008 & 148.0 & 5.4 & 156.8 & 18.5 & 148.0 & 5.4 & 0.059 & $5.61 \%$ \\
\hline $84902-34$ & 0.1575 & 0.0124 & 0.0233 & 0.0005 & 148.4 & 3.4 & 152.6 & 12.3 & 148.4 & 3.4 & 0.040 & $2.74 \%$ \\
\hline $84902-69$ & 0.1568 & 0.0159 & 0.0233 & 0.0007 & 148.5 & 4.3 & 139.9 & 14.6 & 148.5 & 4.3 & 0.052 & $-6.16 \%$ \\
\hline $84902-21$ & 0.1586 & 0.0316 & 0.0234 & 0.0011 & 148.9 & 7.2 & 160.5 & 32.7 & 148.9 & 7.2 & 0.102 & $7.26 \%$ \\
\hline $84902-71$ & 0.1583 & 0.0163 & 0.0234 & 0.0007 & 148.9 & 4.4 & 155.6 & 16.5 & 148.9 & 4.4 & 0.053 & $4.30 \%$ \\
\hline $84902-24$ & 0.1588 & 0.0276 & 0.0234 & 0.0009 & 149.1 & 5.9 & 160.4 & 28.4 & 149.1 & 5.9 & 0.088 & $7.03 \%$ \\
\hline $84902-68$ & 0.1589 & 0.0217 & 0.0235 & 0.0008 & 149.4 & 5.0 & 156.3 & 21.8 & 149.4 & 5.0 & 0.070 & $4.40 \%$ \\
\hline 84902-3 & 0.1590 & 0.0129 & 0.0235 & 0.0007 & 149.5 & 4.7 & 156.5 & 13.1 & 149.5 & 4.7 & 0.042 & $4.47 \%$ \\
\hline $84902-73$ & 0.1591 & 0.0138 & 0.0235 & 0.0005 & 149.7 & 3.5 & 155.3 & 13.8 & 149.7 & 3.5 & 0.045 & $3.60 \%$ \\
\hline $84902-80$ & 0.1588 & 0.0409 & 0.0235 & 0.0017 & 150.0 & 10.9 & 145.1 & 38.5 & 150.0 & 10.9 & 0.133 & $-3.35 \%$ \\
\hline $84902-11$ & 0.1599 & 0.0135 & 0.0236 & 0.0008 & 150.1 & 5.3 & 158.2 & 13.8 & 150.1 & 5.3 & 0.043 & $5.14 \%$ \\
\hline $84902-52$ & 0.1595 & 0.0118 & 0.0236 & 0.0005 & 150.1 & 3.0 & 154.9 & 11.7 & 150.1 & 3.0 & 0.038 & $3.08 \%$ \\
\hline $84902-43$ & 0.1599 & 0.0250 & 0.0236 & 0.0009 & 150.3 & 5.6 & 158.7 & 25.3 & 150.3 & 5.6 & 0.080 & $5.32 \%$ \\
\hline $84902-32$ & 0.1600 & 0.0162 & 0.0236 & 0.0006 & 150.3 & 3.8 & 156.6 & 16.2 & 150.3 & 3.8 & 0.052 & $4.03 \%$ \\
\hline $84902-74$ & 0.1605 & 0.0104 & 0.0237 & 0.0004 & 151.0 & 2.8 & 154.9 & 10.3 & 151.0 & 2.8 & 0.033 & $2.49 \%$ \\
\hline $84902-59$ & 0.1604 & 0.0078 & 0.0237 & 0.0004 & 151.0 & 2.7 & 153.5 & 7.7 & 151.0 & 2.7 & 0.025 & $1.60 \%$ \\
\hline $84902-23$ & 0.1617 & 0.0435 & 0.0237 & 0.0014 & 151.1 & 9.1 & 169.2 & 46.3 & 151.1 & 9.1 & 0.137 & $10.71 \%$ \\
\hline $84902-12$ & 0.1605 & 0.0142 & 0.0237 & 0.0007 & 151.2 & 4.5 & 152.1 & 13.7 & 151.2 & 4.5 & 0.045 & $0.60 \%$ \\
\hline $84902-30$ & 0.1614 & 0.0147 & 0.0238 & 0.0007 & 151.5 & 4.6 & 159.0 & 15.0 & 151.5 & 4.6 & 0.047 & $4.71 \%$ \\
\hline $84902-50$ & 0.1622 & 0.0232 & 0.0239 & 0.0010 & 152.1 & 6.1 & 161.7 & 23.8 & 152.1 & 6.1 & 0.074 & $5.95 \%$ \\
\hline $84902-98$ & 0.1619 & 0.0111 & 0.0239 & 0.0005 & 152.2 & 3.2 & 156.6 & 11.1 & 152.2 & 3.2 & 0.035 & $2.81 \%$ \\
\hline $84902-54$ & 0.1611 & 0.0231 & 0.0239 & 0.0009 & 152.2 & 5.9 & 142.9 & 21.0 & 152.2 & 5.9 & 0.073 & $-6.52 \%$ \\
\hline $84902-2$ & 0.1629 & 0.0187 & 0.0240 & 0.0011 & 152.6 & 6.8 & 164.2 & 19.5 & 152.6 & 6.8 & 0.059 & $7.07 \%$ \\
\hline 84902-61 & 0.1623 & 0.0072 & 0.0240 & 0.0004 & 152.7 & 2.5 & 155.3 & 7.1 & 152.7 & 2.5 & 0.023 & $1.66 \%$ \\
\hline $84902-89$ & 0.1624 & 0.0114 & 0.0240 & 0.0004 & 152.8 & 2.9 & 153.2 & 11.0 & 152.8 & 2.9 & 0.036 & $0.26 \%$ \\
\hline $84902-36$ & 0.1637 & 0.0394 & 0.0240 & 0.0015 & 152.8 & 9.8 & 170.9 & 42.2 & 152.8 & 9.8 & 0.123 & $10.56 \%$ \\
\hline $84902-18$ & 0.1627 & 0.0128 & 0.0240 & 0.0006 & 152.9 & 3.6 & 158.1 & 12.9 & 152.9 & 3.6 & 0.041 & $3.31 \%$ \\
\hline $84902-47$ & 0.1632 & 0.0150 & 0.0240 & 0.0007 & 153.0 & 4.6 & 162.1 & 15.5 & 153.0 & 4.6 & 0.048 & $5.61 \%$ \\
\hline $84902-13$ & 0.1624 & 0.0207 & 0.0240 & 0.0008 & 153.0 & 5.2 & 149.2 & 19.3 & 153.0 & 5.2 & 0.065 & $-2.55 \%$ \\
\hline $84902-41$ & 0.1635 & 0.0104 & 0.0241 & 0.0005 & 153.6 & 3.3 & 157.8 & 10.4 & 153.6 & 3.3 & 0.033 & $2.68 \%$ \\
\hline $84902-62$ & 0.1640 & 0.0181 & 0.0241 & 0.0008 & 153.6 & 5.2 & 163.8 & 18.8 & 153.6 & 5.2 & 0.057 & $6.23 \%$ \\
\hline $84902-27$ & 0.1639 & 0.0213 & 0.0241 & 0.0007 & 153.7 & 4.4 & 161.1 & 21.3 & 153.7 & 4.4 & 0.066 & $4.62 \%$ \\
\hline $84902-40$ & 0.1642 & 0.0145 & 0.0241 & 0.0008 & 153.8 & 5.1 & 162.8 & 14.8 & 153.8 & 5.1 & 0.045 & $5.54 \%$ \\
\hline $84902-60$ & 0.1645 & 0.0187 & 0.0242 & 0.0009 & 154.0 & 5.6 & 165.1 & 19.4 & 154.0 & 5.6 & 0.059 & $6.71 \%$ \\
\hline $84902-97$ & 0.1633 & 0.0157 & 0.0242 & 0.0007 & 154.2 & 4.7 & 144.5 & 14.3 & 154.2 & 4.7 & 0.049 & $-6.68 \%$ \\
\hline $84902-56$ & 0.1655 & 0.0147 & 0.0244 & 0.0006 & 155.1 & 3.5 & 162.1 & 14.7 & 155.1 & 3.5 & 0.045 & $4.29 \%$ \\
\hline $84902-45$ & 0.1657 & 0.0156 & 0.0244 & 0.0007 & 155.3 & 4.4 & 163.4 & 15.9 & 155.3 & 4.4 & 0.048 & $4.99 \%$ \\
\hline $84902-29$ & 0.1647 & 0.0133 & 0.0244 & 0.0006 & 155.3 & 3.8 & 147.6 & 12.3 & 155.3 & 3.8 & 0.042 & $-5.19 \%$ \\
\hline $84902-38$ & 0.1659 & 0.0134 & 0.0244 & 0.0006 & 155.5 & 3.9 & 162.4 & 13.5 & 155.5 & 3.9 & 0.041 & $4.23 \%$ \\
\hline $84902-44$ & 0.1663 & 0.0157 & 0.0244 & 0.0008 & 155.6 & 5.3 & 166.1 & 16.2 & 155.6 & 5.3 & 0.049 & $6.30 \%$ \\
\hline $84902-10$ & 0.1672 & 0.0135 & 0.0245 & 0.0011 & 156.2 & 7.2 & 169.3 & 14.1 & 156.2 & 7.2 & 0.042 & $7.76 \%$ \\
\hline $84902-22$ & 0.1667 & 0.0168 & 0.0245 & 0.0007 & 156.3 & 4.2 & 162.6 & 16.7 & 156.3 & 4.2 & 0.051 & $3.85 \%$ \\
\hline $84902-1$ & 0.1674 & 0.0105 & 0.0246 & 0.0010 & 156.5 & 6.2 & 167.0 & 10.9 & 156.5 & 6.2 & 0.033 & $6.27 \%$ \\
\hline $84902-70$ & 0.1678 & 0.0125 & 0.0247 & 0.0006 & 157.2 & 3.6 & 163.1 & 12.4 & 157.2 & 3.6 & 0.038 & $3.62 \%$ \\
\hline $84902-46$ & 0.1682 & 0.0074 & 0.0248 & 0.0004 & 157.7 & 2.4 & 162.3 & 7.3 & 157.7 & 2.4 & 0.022 & $2.84 \%$ \\
\hline $84902-28$ & 0.1686 & 0.0136 & 0.0248 & 0.0007 & 157.8 & 4.5 & 165.6 & 13.8 & 157.8 & 4.5 & 0.042 & $4.71 \%$ \\
\hline $84902-15$ & 0.1687 & 0.0151 & 0.0248 & 0.0006 & 158.0 & 3.7 & 164.3 & 14.9 & 158.0 & 3.7 & 0.045 & $3.79 \%$ \\
\hline $84902-79$ & 0.1701 & 0.0299 & 0.0249 & 0.0014 & 158.6 & 8.8 & 175.6 & 32.1 & 158.6 & 8.8 & 0.091 & $9.72 \%$ \\
\hline $84902-53$ & 0.1699 & 0.0194 & 0.0250 & 0.0007 & 158.9 & 4.7 & 165.9 & 19.4 & 158.9 & 4.7 & 0.059 & $4.24 \%$ \\
\hline $84902-51$ & 0.1710 & 0.0081 & 0.0252 & 0.0005 & 160.3 & 2.9 & 163.0 & 7.8 & 160.3 & 2.9 & 0.024 & $1.70 \%$ \\
\hline $84902-75$ & 0.1717 & 0.0176 & 0.0252 & 0.0008 & 160.4 & 5.2 & 168.4 & 17.7 & 160.4 & 5.2 & 0.053 & $4.72 \%$ \\
\hline $84902-100$ & 0.1723 & 0.0425 & 0.0252 & 0.0017 & 160.6 & 10.5 & 173.4 & 43.8 & 160.6 & 10.5 & 0.126 & $7.41 \%$ \\
\hline $84902-77$ & 0.1728 & 0.0232 & 0.0253 & 0.0010 & 161.3 & 6.2 & 171.1 & 23.4 & 161.3 & 6.2 & 0.069 & $5.68 \%$ \\
\hline $84902-67$ & 0.1719 & 0.0454 & 0.0254 & 0.0017 & 161.4 & 10.9 & 155.5 & 42.2 & 161.4 & 10.9 & 0.136 & $-3.82 \%$ \\
\hline $84902-19$ & 0.1731 & 0.0162 & 0.0254 & 0.0009 & 161.5 & 5.6 & 171.4 & 16.7 & 161.5 & 5.6 & 0.049 & $5.78 \%$ \\
\hline $84902-65$ & 0.1745 & 0.0289 & 0.0255 & 0.0014 & 162.2 & 9.2 & 179.7 & 30.8 & 162.2 & 9.2 & 0.086 & $9.74 \%$ \\
\hline 84902-99 & 0.1773 & 0.0158 & 0.0260 & 0.0008 & 165.2 & 5.0 & 173.0 & 16.1 & 165.2 & 5.0 & 0.046 & $4.51 \%$ \\
\hline $84902-39$ & 0.1790 & 0.0444 & 0.0261 & 0.0018 & 165.9 & 11.1 & 186.0 & 47.3 & 165.9 & 11.1 & 0.127 & $10.81 \%$ \\
\hline
\end{tabular}


Table 2. U-Pb analytical data for detrital and igneous zircons, identified by sample number and lab.—Continued

\begin{tabular}{|c|c|c|c|c|c|c|c|c|c|c|c|c|}
\hline $84902-93$ & 0.1790 & 0.0143 & 0.0262 & 0.0007 & 166.7 & 4.7 & 174.5 & 14.6 & 166.7 & 4.7 & 0.042 & $4.47 \%$ \\
\hline $84902-33$ & 0.1800 & 0.0229 & 0.0263 & 0.0013 & 167.5 & 8.4 & 177.6 & 23.2 & 167.5 & 8.4 & 0.065 & $5.69 \%$ \\
\hline $84902-63$ & 0.1821 & 0.0202 & 0.0266 & 0.0009 & 169.2 & 5.8 & 180.7 & 20.6 & 169.2 & 5.8 & 0.057 & $6.40 \%$ \\
\hline $84902-55$ & 0.1858 & 0.0356 & 0.0270 & 0.0015 & 171.9 & 9.4 & 190.1 & 37.6 & 171.9 & 9.4 & 0.099 & $9.56 \%$ \\
\hline \multicolumn{13}{|c|}{ 05PH104b, detrital zircons, $\mathrm{n}=96$ of 100, Apatite to Zircon, Inc. } \\
\hline Analysis \# & $207 / 235$ & $\begin{array}{c}2 \sigma \\
\text { error } \\
(\%) \\
\end{array}$ & $206 / 238$ & $\begin{array}{c}2 \sigma \\
\text { error } \\
(\%)\end{array}$ & $\begin{array}{c}206 / 238 \\
\text { age }\end{array}$ & $\begin{array}{l}2 \sigma \\
\text { error } \\
\text { (Ma) }\end{array}$ & $\begin{array}{c}207 / 206 \\
\text { age }\end{array}$ & $\begin{array}{l}2 \sigma \\
\text { error } \\
\text { (Ma) }\end{array}$ & $\begin{array}{l}\text { Best } \\
\text { age } \\
(\mathrm{Ma})\end{array}$ & $\begin{array}{l}2 \sigma \\
\text { error } \\
(\mathrm{Ma})\end{array}$ & Error/age & $\begin{array}{c}\text { Dis- } \\
\text { cordance } \\
(\%)\end{array}$ \\
\hline $84904-74$ & 0.0558 & 0.0088 & 0.0086 & 0.0004 & 55.2 & 2.8 & 54.8 & 9.0 & 55.2 & 2.8 & 0.025 & $-0.72 \%$ \\
\hline $84904-11$ & 0.0565 & 0.0050 & 0.0087 & 0.0002 & 55.8 & 1.3 & 57.5 & 5.3 & 55.8 & 1.3 & 0.012 & $3.08 \%$ \\
\hline $84904-10$ & 0.0569 & 0.0093 & 0.0087 & 0.0003 & 56.1 & 1.9 & 59.7 & 9.9 & 56.1 & 1.9 & 0.017 & $5.97 \%$ \\
\hline $84904-65$ & 0.0572 & 0.0217 & 0.0088 & 0.0010 & 56.3 & 6.1 & 66.0 & 26.0 & 56.3 & 6.1 & 0.054 & $14.73 \%$ \\
\hline $84904-55$ & 0.0576 & 0.0053 & 0.0089 & 0.0003 & 56.8 & 1.8 & 57.4 & 5.5 & 56.8 & 1.8 & 0.016 & $0.92 \%$ \\
\hline $84904-19$ & 0.0579 & 0.0083 & 0.0089 & 0.0003 & 57.1 & 2.0 & 59.1 & 8.7 & 57.1 & 2.0 & 0.017 & $3.37 \%$ \\
\hline $84904-94$ & 0.0580 & 0.0062 & 0.0089 & 0.0003 & 57.2 & 1.8 & 59.5 & 6.5 & 57.2 & 1.8 & 0.016 & $3.89 \%$ \\
\hline $84904-53$ & 0.0585 & 0.0066 & 0.0090 & 0.0003 & 57.7 & 2.1 & 57.1 & 6.7 & 57.7 & 2.1 & 0.018 & $-1.01 \%$ \\
\hline 84904-14 & 0.0589 & 0.0037 & 0.0090 & 0.0004 & 58.0 & 2.8 & 61.6 & 4.2 & 58.0 & 2.8 & 0.024 & $5.80 \%$ \\
\hline $84904-89$ & 0.0593 & 0.0063 & 0.0091 & 0.0003 & 58.4 & 1.8 & 61.7 & 6.8 & 58.4 & 1.8 & 0.016 & $5.39 \%$ \\
\hline $84904-54$ & 0.0594 & 0.0068 & 0.0091 & 0.0003 & 58.5 & 2.1 & 61.0 & 7.2 & 58.5 & 2.1 & 0.018 & $4.08 \%$ \\
\hline $84904-44$ & 0.0599 & 0.0035 & 0.0092 & 0.0002 & 59.1 & 1.1 & 58.4 & 3.5 & 59.1 & 1.1 & 0.009 & $-1.09 \%$ \\
\hline 84904-71 & 0.0601 & 0.0098 & 0.0092 & 0.0004 & 59.2 & 2.8 & 63.2 & 10.6 & 59.2 & 2.8 & 0.023 & $6.45 \%$ \\
\hline $84904-24$ & 0.0600 & 0.0046 & 0.0092 & 0.0002 & 59.2 & 1.3 & 59.1 & 4.7 & 59.2 & 1.3 & 0.011 & $-0.21 \%$ \\
\hline $84904-12$ & 0.0603 & 0.0038 & 0.0092 & 0.0005 & 59.3 & 2.9 & 62.6 & 4.3 & 59.3 & 2.9 & 0.024 & $5.15 \%$ \\
\hline $84904-64$ & 0.0603 & 0.0101 & 0.0092 & 0.0004 & 59.3 & 2.6 & 62.1 & 10.7 & 59.3 & 2.6 & 0.022 & $4.45 \%$ \\
\hline $84904-93$ & 0.0606 & 0.0052 & 0.0093 & 0.0002 & 59.7 & 1.6 & 61.3 & 5.4 & 59.7 & 1.6 & 0.013 & $2.54 \%$ \\
\hline $84904-67$ & 0.0607 & 0.0062 & 0.0093 & 0.0003 & 59.7 & 2.1 & 62.7 & 6.7 & 59.7 & 2.1 & 0.018 & $4.79 \%$ \\
\hline $84904-15$ & 0.0607 & 0.0052 & 0.0093 & 0.0002 & 59.8 & 1.4 & 60.8 & 5.4 & 59.8 & 1.4 & 0.012 & $1.70 \%$ \\
\hline $84904-43$ & 0.0610 & 0.0056 & 0.0093 & 0.0003 & 60.0 & 1.9 & 63.6 & 6.0 & 60.0 & 1.9 & 0.016 & $5.72 \%$ \\
\hline $84904-28$ & 0.0609 & 0.0048 & 0.0094 & 0.0002 & 60.0 & 1.5 & 61.3 & 4.9 & 60.0 & 1.5 & 0.013 & $2.07 \%$ \\
\hline $84904-68$ & 0.0610 & 0.0074 & 0.0094 & 0.0003 & 60.1 & 2.1 & 58.9 & 7.3 & 60.1 & 2.1 & 0.018 & $-2.08 \%$ \\
\hline $84904-8$ & 0.0613 & 0.0112 & 0.0094 & 0.0004 & 60.3 & 2.6 & 65.0 & 12.2 & 60.3 & 2.6 & 0.022 & $7.19 \%$ \\
\hline $84904-61$ & 0.0614 & 0.0100 & 0.0094 & 0.0004 & 60.4 & 2.8 & 63.9 & 10.7 & 60.4 & 2.8 & 0.023 & $5.41 \%$ \\
\hline $84904-96$ & 0.0616 & 0.0126 & 0.0094 & 0.0004 & 60.6 & 2.8 & 64.9 & 13.6 & 60.6 & 2.8 & 0.023 & $6.57 \%$ \\
\hline $84904-29$ & 0.0617 & 0.0118 & 0.0094 & 0.0006 & 60.6 & 3.7 & 66.9 & 13.4 & 60.6 & 3.7 & 0.031 & $9.40 \%$ \\
\hline $84904-20$ & 0.0616 & 0.0088 & 0.0094 & 0.0005 & 60.6 & 2.9 & 65.2 & 9.7 & 60.6 & 2.9 & 0.024 & $7.05 \%$ \\
\hline $84904-37$ & 0.0618 & 0.0048 & 0.0095 & 0.0002 & 60.9 & 1.3 & 63.2 & 5.0 & 60.9 & 1.3 & 0.011 & $3.65 \%$ \\
\hline $84904-56$ & 0.0618 & 0.0060 & 0.0095 & 0.0003 & 60.9 & 1.8 & 62.4 & 6.2 & 60.9 & 1.8 & 0.014 & $2.46 \%$ \\
\hline $84904-50$ & 0.0619 & 0.0089 & 0.0095 & 0.0004 & 60.9 & 2.5 & 63.2 & 9.3 & 60.9 & 2.5 & 0.021 & $3.60 \%$ \\
\hline $84904-22$ & 0.0620 & 0.0072 & 0.0095 & 0.0003 & 61.0 & 1.9 & 64.5 & 7.7 & 61.0 & 1.9 & 0.015 & $5.47 \%$ \\
\hline $84904-36$ & 0.0620 & 0.0037 & 0.0095 & 0.0002 & 61.0 & 1.3 & 62.7 & 3.9 & 61.0 & 1.3 & 0.011 & $2.69 \%$ \\
\hline $84904-45$ & 0.0623 & 0.0083 & 0.0095 & 0.0005 & 61.2 & 3.1 & 67.0 & 9.4 & 61.2 & 3.1 & 0.026 & $8.60 \%$ \\
\hline $84904-41$ & 0.0626 & 0.0041 & 0.0096 & 0.0002 & 61.5 & 1.5 & 63.9 & 4.4 & 61.5 & 1.5 & 0.012 & $3.75 \%$ \\
\hline 84904-76 & 0.0626 & 0.0046 & 0.0096 & 0.0003 & 61.6 & 1.6 & 62.4 & 4.8 & 61.6 & 1.6 & 0.013 & $1.32 \%$ \\
\hline $84904-17$ & 0.0633 & 0.0048 & 0.0097 & 0.0002 & 62.4 & 1.2 & 61.8 & 4.8 & 62.4 & 1.2 & 0.010 & $-0.89 \%$ \\
\hline 84904-34 & 0.0634 & 0.0065 & 0.0097 & 0.0003 & 62.4 & 1.9 & 63.6 & 6.8 & 62.4 & 1.9 & 0.015 & $1.94 \%$ \\
\hline $84904-73$ & 0.0635 & 0.0080 & 0.0097 & 0.0004 & 62.5 & 2.3 & 63.9 & 8.3 & 62.5 & 2.3 & 0.019 & $2.29 \%$ \\
\hline $84904-85$ & 0.0636 & 0.0063 & 0.0098 & 0.0003 & 62.6 & 2.1 & 63.9 & 6.5 & 62.6 & 2.1 & 0.016 & $2.13 \%$ \\
\hline $84904-32$ & 0.0637 & 0.0087 & 0.0098 & 0.0004 & 62.6 & 2.6 & 65.8 & 9.3 & 62.6 & 2.6 & 0.021 & $4.81 \%$ \\
\hline $84904-30$ & 0.0637 & 0.0039 & 0.0098 & 0.0002 & 62.7 & 1.5 & 64.1 & 4.1 & 62.7 & 1.5 & 0.012 & $2.15 \%$ \\
\hline $84904-13$ & 0.0638 & 0.0031 & 0.0098 & 0.0003 & 62.8 & 2.1 & 63.9 & 3.3 & 62.8 & 2.1 & 0.017 & $1.74 \%$ \\
\hline $84904-91$ & 0.0639 & 0.0046 & 0.0098 & 0.0003 & 62.8 & 1.8 & 64.2 & 4.9 & 62.8 & 1.8 & 0.014 & $2.26 \%$ \\
\hline $84904-23$ & 0.0638 & 0.0064 & 0.0098 & 0.0003 & 62.8 & 1.6 & 62.9 & 6.4 & 62.8 & 1.6 & 0.013 & $0.07 \%$ \\
\hline $84904-25$ & 0.0639 & 0.0046 & 0.0098 & 0.0002 & 62.9 & 1.4 & 61.3 & 4.5 & 62.9 & 1.4 & 0.011 & $-2.66 \%$ \\
\hline $84904-38$ & 0.0640 & 0.0073 & 0.0098 & 0.0003 & 62.9 & 2.0 & 64.9 & 7.6 & 62.9 & 2.0 & 0.015 & $3.10 \%$ \\
\hline 84904-77 & 0.0640 & 0.0054 & 0.0098 & 0.0003 & 63.0 & 2.0 & 66.5 & 5.7 & 63.0 & 2.0 & 0.016 & $5.27 \%$ \\
\hline 84904-52 & 0.0640 & 0.0083 & 0.0098 & 0.0004 & 63.0 & 2.4 & 65.5 & 8.7 & 63.0 & 2.4 & 0.019 & $3.81 \%$ \\
\hline $84904-75$ & 0.0642 & 0.0069 & 0.0098 & 0.0003 & 63.0 & 2.0 & 66.5 & 7.3 & 63.0 & 2.0 & 0.016 & $5.14 \%$ \\
\hline $84904-27$ & 0.0642 & 0.0041 & 0.0098 & 0.0002 & 63.1 & 1.4 & 64.9 & 4.3 & 63.1 & 1.4 & 0.011 & $2.65 \%$ \\
\hline $84904-5$ & 0.0642 & 0.0093 & 0.0098 & 0.0003 & 63.2 & 2.1 & 65.2 & 9.6 & 63.2 & 2.1 & 0.017 & $3.05 \%$ \\
\hline $84904-72$ & 0.0644 & 0.0067 & 0.0099 & 0.0003 & 63.3 & 2.0 & 64.5 & 6.8 & 63.3 & 2.0 & 0.016 & $1.87 \%$ \\
\hline 84904-26 & 0.0647 & 0.0050 & 0.0099 & 0.0002 & 63.6 & 1.2 & 65.2 & 5.2 & 63.6 & 1.2 & 0.010 & $2.37 \%$ \\
\hline $84904-40$ & 0.0648 & 0.0098 & 0.0099 & 0.0004 & 63.7 & 2.6 & 68.3 & 10.6 & 63.7 & 2.6 & 0.020 & $6.75 \%$ \\
\hline $84904-97$ & 0.0649 & 0.0129 & 0.0099 & 0.0006 & 63.7 & 4.1 & 71.7 & 14.9 & 63.7 & 4.1 & 0.032 & $11.22 \%$ \\
\hline $84904-46$ & 0.0649 & 0.0057 & 0.0099 & 0.0003 & 63.8 & 1.7 & 66.5 & 6.0 & 63.8 & 1.7 & 0.014 & $4.16 \%$ \\
\hline $84904-51$ & 0.0651 & 0.0051 & 0.0100 & 0.0003 & 63.9 & 1.6 & 66.4 & 5.3 & 63.9 & 1.6 & 0.013 & $3.71 \%$ \\
\hline 84904-7 & 0.0650 & 0.0062 & 0.0100 & 0.0003 & 64.0 & 1.8 & 64.9 & 6.3 & 64.0 & 1.8 & 0.014 & $1.39 \%$ \\
\hline 84904-2 & 0.0651 & 0.0074 & 0.0100 & 0.0004 & 64.0 & 2.5 & 66.1 & 7.6 & 64.0 & 2.5 & 0.019 & $3.13 \%$ \\
\hline $84904-80$ & 0.0652 & 0.0047 & 0.0100 & 0.0003 & 64.1 & 1.8 & 65.6 & 5.0 & 64.1 & 1.8 & 0.014 & $2.31 \%$ \\
\hline $84904-66$ & 0.0654 & 0.0137 & 0.0100 & 0.0005 & 64.1 & 3.2 & 70.2 & 15.0 & 64.1 & 3.2 & 0.025 & $8.63 \%$ \\
\hline $84904-58$ & 0.0655 & 0.0057 & 0.0100 & 0.0003 & 64.4 & 2.1 & 65.9 & 6.0 & 64.4 & 2.1 & 0.016 & $2.38 \%$ \\
\hline $84904-78$ & 0.0655 & 0.0048 & 0.0100 & 0.0002 & 64.4 & 1.5 & 66.3 & 5.0 & 64.4 & 1.5 & 0.012 & $2.91 \%$ \\
\hline
\end{tabular}


Table 2

Table 2. U-Pb analytical data for detrital and igneous zircons, identified by sample number and lab.-Continued

\begin{tabular}{|c|c|c|c|c|c|c|c|c|c|c|c|c|}
\hline $84904-4$ & 0.0655 & 0.0074 & 0.0100 & 0.0003 & 64.4 & 2.0 & 65.8 & 7.7 & 64.4 & 2.0 & 0.015 & $2.17 \%$ \\
\hline $84904-82$ & 0.0658 & 0.0088 & 0.0101 & 0.0003 & 64.6 & 1.9 & 67.0 & 9.1 & 64.6 & 1.9 & 0.015 & $3.55 \%$ \\
\hline $84904-48$ & 0.0658 & 0.0069 & 0.0101 & 0.0003 & 64.6 & 2.0 & 68.4 & 7.4 & 64.6 & 2.0 & 0.015 & $5.44 \%$ \\
\hline $84904-31$ & 0.0660 & 0.0069 & 0.0101 & 0.0003 & 64.8 & 2.1 & 68.8 & 7.5 & 64.8 & 2.1 & 0.016 & $5.91 \%$ \\
\hline $84904-57$ & 0.0661 & 0.0101 & 0.0101 & 0.0004 & 64.9 & 2.8 & 67.9 & 10.7 & 64.9 & 2.8 & 0.022 & $4.48 \%$ \\
\hline $84904-59$ & 0.0662 & 0.0047 & 0.0101 & 0.0003 & 65.0 & 1.7 & 65.0 & 4.9 & 65.0 & 1.7 & 0.013 & $-0.03 \%$ \\
\hline $84904-90$ & 0.0664 & 0.0170 & 0.0101 & 0.0009 & 65.0 & 5.6 & 73.8 & 19.8 & 65.0 & 5.6 & 0.043 & $11.84 \%$ \\
\hline $84904-16$ & 0.0663 & 0.0097 & 0.0102 & 0.0004 & 65.1 & 2.4 & 67.1 & 10.0 & 65.1 & 2.4 & 0.018 & $3.01 \%$ \\
\hline $84904-49$ & 0.0664 & 0.0052 & 0.0102 & 0.0003 & 65.3 & 1.7 & 65.9 & 5.3 & 65.3 & 1.7 & 0.013 & $0.98 \%$ \\
\hline $84904-63$ & 0.0670 & 0.0095 & 0.0102 & 0.0005 & 65.7 & 2.9 & 70.1 & 10.3 & 65.7 & 2.9 & 0.022 & $6.32 \%$ \\
\hline $84904-21$ & 0.0669 & 0.0053 & 0.0103 & 0.0003 & 65.9 & 1.6 & 62.6 & 5.1 & 65.9 & 1.6 & 0.012 & $-5.20 \%$ \\
\hline $84904-42$ & 0.0671 & 0.0024 & 0.0103 & 0.0002 & 65.9 & 1.1 & 67.7 & 2.5 & 65.9 & 1.1 & 0.008 & $2.57 \%$ \\
\hline $84904-84$ & 0.0672 & 0.0090 & 0.0103 & 0.0003 & 66.0 & 2.0 & 69.8 & 9.5 & 66.0 & 2.0 & 0.015 & $5.52 \%$ \\
\hline $84904-81$ & 0.0671 & 0.0044 & 0.0103 & 0.0002 & 66.1 & 1.5 & 63.0 & 4.2 & 66.1 & 1.5 & 0.012 & $-4.84 \%$ \\
\hline 84904-79 & 0.0676 & 0.0038 & 0.0104 & 0.0002 & 66.4 & 1.2 & 67.4 & 3.9 & 66.4 & 1.2 & 0.009 & $1.57 \%$ \\
\hline $84904-70$ & 0.0681 & 0.0111 & 0.0104 & 0.0004 & 66.8 & 2.6 & 69.7 & 11.6 & 66.8 & 2.6 & 0.019 & $4.18 \%$ \\
\hline $84904-86$ & 0.0688 & 0.0058 & 0.0105 & 0.0003 & 67.5 & 2.2 & 69.7 & 6.1 & 67.5 & 2.2 & 0.016 & $3.19 \%$ \\
\hline $84904-87$ & 0.0692 & 0.0077 & 0.0106 & 0.0004 & 67.8 & 2.5 & 71.3 & 8.2 & 67.8 & 2.5 & 0.018 & $4.82 \%$ \\
\hline $84904-69$ & 0.0694 & 0.0099 & 0.0106 & 0.0005 & 68.0 & 3.0 & 71.6 & 10.6 & 68.0 & 3.0 & 0.022 & $4.93 \%$ \\
\hline $84904-3$ & 0.0700 & 0.0067 & 0.0107 & 0.0003 & 68.6 & 2.0 & 71.4 & 7.1 & 68.6 & 2.0 & 0.015 & $3.97 \%$ \\
\hline 84904-1 & 0.0703 & 0.0115 & 0.0107 & 0.0007 & 68.8 & 4.2 & 74.5 & 12.4 & 68.8 & 4.2 & 0.030 & $7.58 \%$ \\
\hline 84904-9 & 0.0704 & 0.0109 & 0.0108 & 0.0005 & 69.0 & 3.3 & 73.4 & 11.8 & 69.0 & 3.3 & 0.024 & $6.04 \%$ \\
\hline 84904-39 & 0.0705 & 0.0103 & 0.0108 & 0.0005 & 69.1 & 3.0 & 73.3 & 11.1 & 69.1 & 3.0 & 0.022 & $5.82 \%$ \\
\hline $84904-98$ & 0.0722 & 0.0186 & 0.0110 & 0.0007 & 70.5 & 4.3 & 79.0 & 20.9 & 70.5 & 4.3 & 0.031 & $10.77 \%$ \\
\hline $84904-92$ & 0.0746 & 0.0129 & 0.0114 & 0.0005 & 72.9 & 3.2 & 78.6 & 14.0 & 72.9 & 3.2 & 0.022 & $7.25 \%$ \\
\hline $84904-60$ & 0.0856 & 0.0091 & 0.0130 & 0.0005 & 83.2 & 2.9 & 88.2 & 9.7 & 83.2 & 2.9 & 0.017 & $5.66 \%$ \\
\hline $84904-47$ & 0.1079 & 0.0168 & 0.0162 & 0.0007 & 103.8 & 4.3 & 109.9 & 17.6 & 103.8 & 4.3 & 0.021 & $5.61 \%$ \\
\hline $84904-88$ & 0.1318 & 0.0087 & 0.0197 & 0.0004 & 125.5 & 2.8 & 128.6 & 8.7 & 125.5 & 2.8 & 0.011 & $2.41 \%$ \\
\hline $84904-83$ & 0.1349 & 0.0089 & 0.0201 & 0.0005 & 128.2 & 2.9 & 133.7 & 9.1 & 128.2 & 2.9 & 0.011 & $4.11 \%$ \\
\hline $84904-100$ & 0.6675 & 0.0238 & 0.0833 & 0.0014 & 516.0 & 8.6 & 531.7 & 19.6 & 516.0 & 8.6 & 0.008 & $2.95 \%$ \\
\hline $84904-95$ & 0.6854 & 0.0251 & 0.0852 & 0.0014 & 526.9 & 8.8 & 542.1 & 20.4 & 526.9 & 8.8 & 0.008 & $2.81 \%$ \\
\hline $84904-99$ & 1.4632 & 0.0561 & 0.1543 & 0.0028 & 925.1 & 17.0 & 890.6 & 35.0 & 925.1 & 17.0 & 0.009 & $-3.87 \%$ \\
\hline $84904-33$ & 3.2836 & 0.0963 & 0.2559 & 0.0061 & 1468.9 & 34.8 & 1489.2 & 46.2 & 1489.2 & 46.2 & 0.016 & $1.36 \%$ \\
\hline $84904-35$ & 3.6760 & 0.1112 & 0.2762 & 0.0062 & 1572.0 & 35.5 & 1558.6 & 48.6 & 1558.6 & 48.6 & 0.016 & $-0.86 \%$ \\
\hline $84904-6$ & 4.0685 & 0.1239 & 0.2975 & 0.0081 & 1678.9 & 45.7 & 1608.2 & 52.3 & 1608.2 & 52.3 & 0.016 & $-4.40 \%$ \\
\hline $84904-62$ & 4.0953 & 0.0868 & 0.2952 & 0.0053 & 1667.4 & 29.9 & 1635.8 & 35.5 & 1635.8 & 35.5 & 0.011 & $-1.93 \%$ \\
\hline
\end{tabular}


This page intentionally left blank 


\section{Appendix: Analytical Methods}

\section{U-Pb Zircon LA-ICP-MS Techniques (University of British Columbia)}

Zircons are separated from their host rocks using conventional mineral separation methods and sectioned in an epoxy grain mount along with grains of internationally accepted standard zircon (FC-1, a 1100-Ma zircon standard), and brought to a very high polish. The grains are examined using a stagemounted cathodoluminescence imaging setup that makes it possible to detect the presence of altered zones or inherited cores within the zircon. The highest quality portions of each grain, free of alteration, inclusion, or cores, are selected for analysis. The surface of the mount is then washed for $\sim 10$ minutes with dilute nitric acid and rinsed in ultraclean water. Analyses are carried out using a New Wave $213 \mathrm{~nm}$ Nd-YAG laser coupled to a Thermo Finnigan Element 2 high resolution ICP-MS (inductively coupled plasma mass spectrometer). Ablation takes place within a New Wave "Supercell" ablation chamber, which is designed to achieve very high efficiency entrainment of aerosols into the carrier gas. Helium is used as the carrier gas for all experiments, and gas flow rates, together with other parameters such as torch position, are optimized before beginning a series of analyses. We typically use a 25 -micron spot with 60 percent laser power and do line scans rather than spot analyses in order to avoid withinrun elemental fractions. Each analysis consists of a 7-second background measurement (laser off) followed by a $\sim 28$-second data acquisition period with the laser firing. A typical analytical session consists of four analyses of the standard zircon, followed by four analyses of unknown zircons, two standards, four unknowns, and so forth, and finally four standard analyses. Data are reduced using the GLITTER software package developed by the GEMOC group at Macquarrie University, which subtracts background measurements, propagates analytical errors, and calculates isotopic ratios and ages. This application generates a time-resolved record of each laser shot. For detrital zircon samples, 60-100 grains are analysed and displayed on concordia and probability plots. Plotting of the analytical results employs ISOPLOT 3.00 software (Ludwig, 2003).

\section{U-Pb Zircon SHRIMP-RG Techniques (U.S. Geo- logical Survey-Stanford University)}

Zircon separations were done at the U.S. Geological Survey in Anchorage using standard density and magnetic separation techniques. At the jointly operated USGS-Stanford SHRIMPRG lab at Stanford, zircons were hand picked for final purity, mounted on double-stick tape on glass slides in 1x6-mm rows, cast in epoxy, ground and polished to a 1-micron finish on a disc $25 \mathrm{~mm}$ in diameter by $4 \mathrm{~mm}$ thick. All grains were imaged with transmitted light and reflected light (and incident light if needed) on a petrographic microscope, and with cathodoluminescence and back scattered electrons as needed on a JEOL 5600 SEM to identify internal structure, inclusions, and physical defects. The mounted grains were washed with $1 \mathrm{~N} \mathrm{HCl}$ or EDTA solution (if acid soluble) and distilled water, dried in a vacuum oven, and coated with Au. Mounts typically sit in a loading chamber at high pressure ( $10^{-7}$ torr) for several hours before being moved into the source chamber of the SHRIMP-RG. Secondary ions are generated from the target spot with an $\mathrm{O}_{2}^{-}$primary ion beam varying from 4 to $6 \mathrm{nA}$. The primary ion beam typically produces a spot with a diameter of 20-40 microns and a depth of 1-2 microns for an analysis time of 9-12 minutes. Nine peaks are measured sequentially for zircons (the SHRIMP-RG is limited to a single collector, usually an EDP electron multiplier): ${ }^{90} \mathrm{Zr}_{2}{ }^{16} \mathrm{O},{ }^{204} \mathrm{~Pb}$, Bgd $\left(0.050\right.$ mass units above $\left.{ }^{204} \mathrm{~Pb}\right),{ }^{206} \mathrm{~Pb},{ }^{207} \mathrm{~Pb},{ }^{208} \mathrm{~Pb},{ }^{238} \mathrm{U},{ }^{248} \mathrm{Th}^{16} \mathrm{O}$, and ${ }^{254} \mathrm{U}^{16} \mathrm{O}$. Autocentering on selected peaks and guide peaks for low or variable abundance peaks (that is, ${ }^{96} \mathrm{Zr}^{216} \mathrm{O}, 0.165$ mass unit below ${ }^{204} \mathrm{~Pb}$ ) are used to improve the reliability of locating peak centers. The number of scans through the mass sequence and counting times on each peak are varied according to sample age and $U$ and $T h$ concentrations to improve counting statistics and age precision. Measurements are made at mass resolutions of 6,000-8,000 (10 percent peak height), which eliminates all interfering atomic species. The SHRIMP-RG was designed to provide higher mass resolution than the standard forward geometry of the SHRIMP I and II (Clement and Compston, 1994). This design also provides very clean backgrounds and, combined with the high mass resolution, the acid washing of the mount, and rastering the primary beam for $90-120$ seconds over the area to be analyzed before data are collected, assures that any counts found at mass of ${ }^{204} \mathrm{~Pb}$ are actually $\mathrm{Pb}$ from the zircon and not surface contamination. In practice, greater than 95 percent of the spots analyzed have no common $\mathrm{Pb}$. Concentration data for zircons are standardized against zircon standard SL-13 (238 ppm U) or CZ3 (550 ppm U) and age data against AS3 and AS57 zircons (1098 Ma) from the Duluth Gabbro (Paces and Miller, 1993), RG-6 (1440 Ma, granite of Oak Creek stock; Bickford and others, 1989), or R33 (419 Ma, quartz diorite of Braintree complex, Vermont; Black and others, 2004), which are analyzed repeatedly throughout the duration of the analytical session. Data reduction follows the methods described by Williams (1998) and Ireland and Williams (2003) and use the Squid and Isoplot programs of Ludwig $(2001,2003)$.

\section{U-Pb zircon LA-ICP-MS Techniques (Apatite to Zircon, Inc.)}

Mineral separates were obtained at the laboratories of Apatite to Zircon, Inc., in Viola, Idaho. Lithium polytungstate and a centrifuge were used in place of the conventional Wilfley table, thus guarding against loss of zircon grains that might inadvertently be washed away, undetected, in the conventional method. Zircons (both standards and unknowns) were then mounted in $1-\mathrm{cm}^{2}$ epoxy wafers and ground down to expose internal grain surfaces before final polishing. Grains, and the locations for 
laser spots on these grains, were selected for analysis from all sizes and morphologies present using transmitted light with an optical microscope at a magnification of $x 2000$. This approach is used instead of cathodoluminescence 2-D imaging because it allows the recognition and characterization of features below the surface of individual grains, including the presence of inclusions and the orientation of cracks, which could otherwise result in spurious isotopic counts.

Isotopic analyses were performed with a New Wave UP-213 laser ablation system in conjunction with a ThermoFinnigan Element2 single collector double-focusing magnetic sector inductively coupled plasma-mass spectrometer (LAICP-MS) in the GeoAnalytical Lab at Washington State University. In comparison to a quadropole ICP-MS, the Element2 has flat-top peaks and higher sensitivity, resulting in larger $\mathrm{Pb}$ signals, better counting statistics, and more precise and accurate measurement of isotopic ratios. For all analyses (both standard and unknown), the diameter of the laser beam was set at $20 \mu \mathrm{m}$ and the laser frequency was set at $5 \mathrm{~Hz}$, yielding ablation pits $\sim 10-15 \mu \mathrm{m}$ deep. He and Ar gas were used to deliver the ablated material into the plasma source of the mass spectrometer. Each analysis of 250 cycles took approximately 30 seconds to com- plete and consisted of a 6-second integration on peaks with the laser turned off (for background measurements) followed by a 25 -second integration with the laser firing. A delay of as much as 30 seconds occurred between analyses in order to purge the previous analysis and prepare for the next. The isotopes measured included ${ }^{202} \mathrm{Hg},{ }^{204}(\mathrm{Hg}+\mathrm{Pb}),{ }^{206} \mathrm{~Pb},{ }^{207} \mathrm{~Pb},{ }^{208} \mathrm{~Pb},{ }^{232} \mathrm{Th},{ }^{235} \mathrm{U}$, and ${ }^{238} \mathrm{U}$. The Element2 detector was set at analog mode for ${ }^{232} \mathrm{Th}$ and ${ }^{238} \mathrm{U}$ and at pulse counting mode for all other isotopes. Common $\mathrm{Pb}$ correction was made by using the measured ${ }^{204} \mathrm{~Pb}$ content and assuming an initial $\mathrm{Pb}$ composition from Stacey and Kramers (1975).

Interelement fractionation of $\mathrm{Pb} / \mathrm{U}$ is generally $<20$ percent, whereas fractionation of $\mathrm{Pb}$ isotopes is generally $<5$ percent. At the beginning of each LA-ICP-MS session, zircon standards (Peixe and FC1) were analyzed until fractionation was stable and the variance in the measured ${ }^{206} \mathrm{~Pb} /{ }^{238} \mathrm{U}$ and ${ }^{207} \mathrm{~Pb} /{ }^{206} \mathrm{~Pb}$ ratios was at or near 1 percent. In order to correct for interelement fractionation during the session, these standards were generally reanalyzed after each 15-25 unknowns. Fractionation also increases with depth into the laser pit. The accepted isotopic ratios were accordingly determined by least-squares projection through the measured values back to the initial determination. 
This page intentionally left blank 

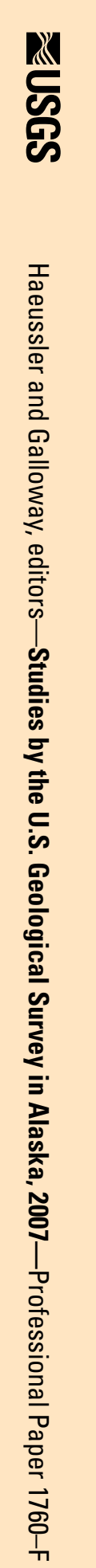